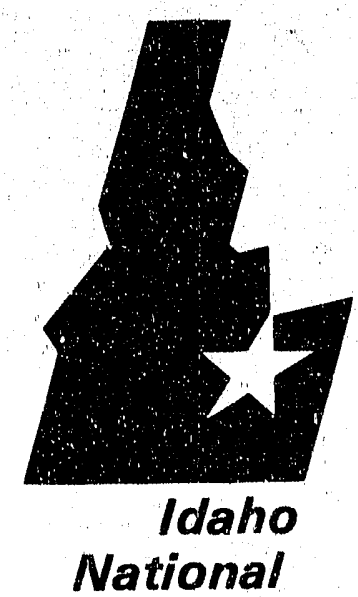

Engineering

Laboratory

Managed

by the U.S.

Department

of Energy
EGG-WTD-9845

November 1991

APR 271992

INFORMAL REPORT
A Computational Model for Viscous
Fluid Flow, Heat Transfer, and Melting in In Situ Vitrification Melt Pools

P. R. McHugh

J. D. Ramshaw 
This document contains new concepts or the author(s) interpretation of new calculations and/or measurements; accordingly, EG\&G Idaho, Inc. is required by the United States Government to include the following disclaimer:

\section{DISCLAIMER}

This report was prepared as an account of work sponsored by an agency of the United States Government. Neither the United States Government nor any agency thereof, nor any of their employees, makes any warranty, express o" implied, or assumes any legal liability or responsibility for the accuracy, completeness, or usefulness of any information, apparatus, product or process disclosed, or represents that its use would not infringe privately owned rights. Reterences herein to any specific commercial product, process, or service by trade name, trademark, manufacturer, or otherwise, does not necessarily constitute or imply its endorsement, recommendation, or favoring by the United States Government or any agency thereof. The views and opinions of authors expressed herein do not necessarily state or reflect those of the United States Government or any agency thereot. 


\title{
A Computational Model for Viscous Fluid Flow, Heat Transfer, and Melting in In Situ Vitrification Melt Pools
}

\author{
P. R. McHugh and J. D. Ramshaw
}

Published November 1991

Idaino National Engineering Laboratory

EG\&G idaho, Inc.

Idaho Falls, ID 83415

Prepared for the

U.S. Department of Energy

Office of Environmental Restoration \& Waste Management

Under DOE Field Office, Idaho

Contract DE-AC07-76IDO1570

$$
\text { wing }
$$




\section{A Computational Model for Viscous Fluid Flow, Heat Transfer, and Melting in In Situ Vitrification Melt Pools}

EGG-WTD-9845

Prepared by:

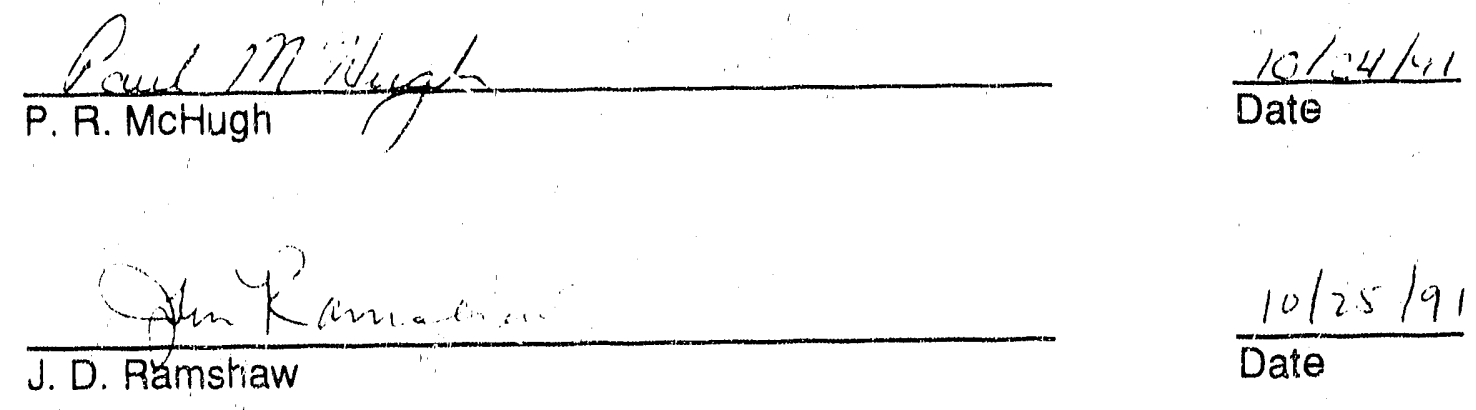

Reviewed by:
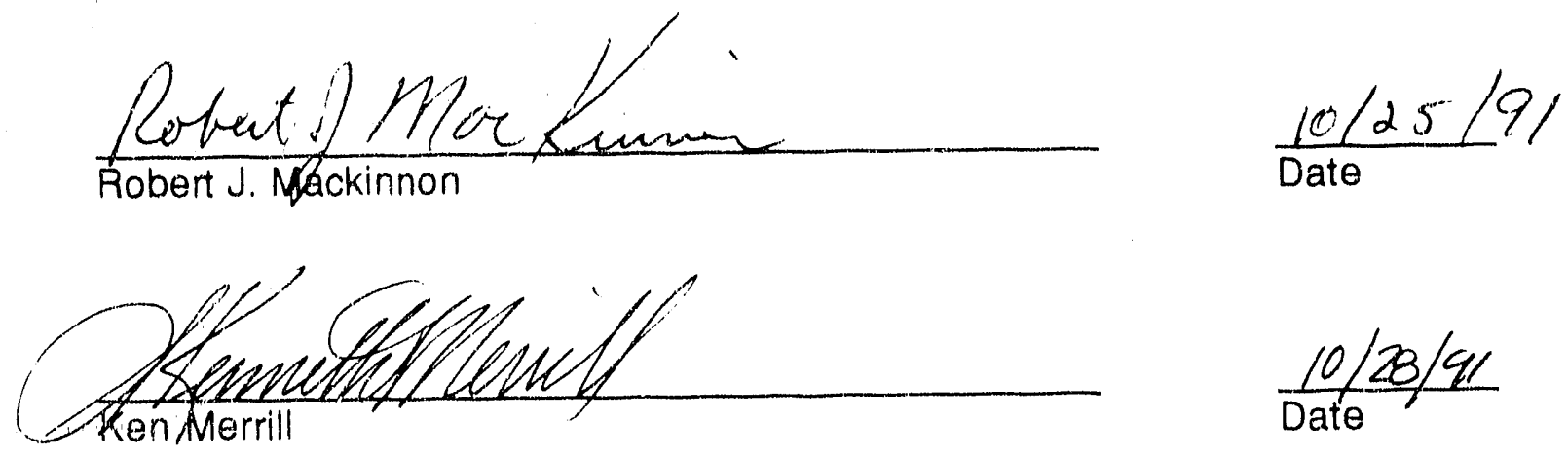


\begin{abstract}
MAGMA is a FORTRAN computer code designed to simulate viscous flow in in situ vitrification melt pools. It models three-dimensional, incompressible, viscous flow and heat transfer. The momentum equation is coupled to the temperature field through the buoyancy force terms arising from the Boussinesq approximation. All fluid properties, except density, are assumed variable. Density is assumed constant except in the buoyancy force terms in the momentum equation. A simple melting model based on the enthalpy method allows the study of the melt front progression and latent heat effects. An indirect addressirg scheme used in the numerical solution of the momentum equation avoids unnecessary calculations in cells devoid of liquid. Two-dimensional calculations can be performed using either rectangular or cylindrical coordinates, while three-dimensional calculations use rectangular coordinates. All derivatives are approximated by finite differences. The incompressible Navier-Stokes equations are solved using a new fully implicit iterative technique, while the energy equation is differenced explicitly in time. Spatial derivatives are written in conservative form using a uniform, rectangular, staggered mesh based on the marker and cell placement of variables. Convertive terms are differenced using a weighted average of centered and donor cell differencing to ensure numerical stability. Complete descriptions of MAGMA governing equations, numerics, code structure, and code verification are provided.
\end{abstract}




\section{CONTENTS}

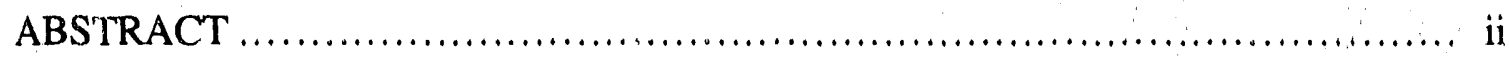

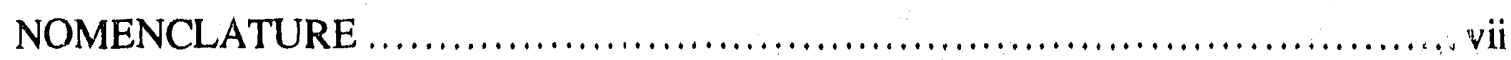

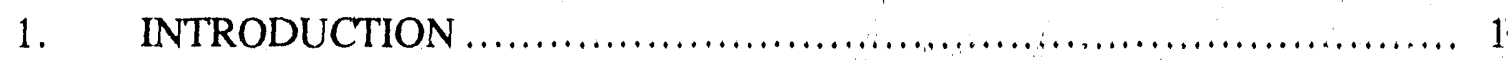

2. GOVERNING EQUATIONS AND NUMERICS .......................... 3

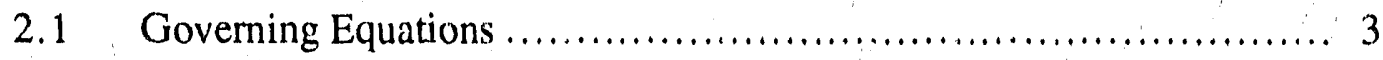

2.1.1 Incompressible Navier-Stokes Equations ................... 3

2.1 .2 Energy Equation.......................................... 6

2.1.3 State Relation and Melting Model .........................

2.2 Temporal Differencing and Time Integration Procedure............... 9

2.2.1 Incompressible Navier-Stokes Equations ..................... 9

2.2.2 Energy Equation.......................................... 12

2.3 Spatial Differencing .......................................... 14

2.3.1 Finite Difference Mesh........................................ 14

2.3.2 Differencing Notation......................................... 17

2.3.3 Incompressible Navier-Stokes Equations ....................... 20

2.3.4 Energy Equation........................................ 22

2.4 Boundary Conditions ......................................... 23

2.4.1 Velocity Boundary Conditions.................................. 23

2.4.2 Temperature Boundary Conditions................................26

2.4 .3 Boundary Conditions Summary ............................ 28

3. CODE DESCRIPTION ............................................. 30

3.1 Indirect Addressing Scheme .................................. 30

3.2 Overall Program Flow Chart..................................... 31

3.3 Subroutine Organization and Description................................ 33

3.4 Code Options and Input ...................................... 36

3.5 Code Output.................................................. 40

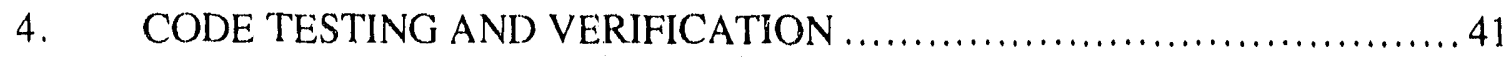

5. SUMMARY AND RECOMMENDATIONS FOR FURTHER CODE

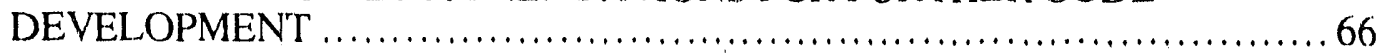

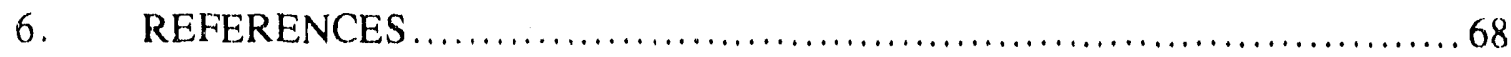


APPENDIX A- AVERAGING TECHNIQUES $\ldots \ldots \ldots \ldots \ldots \ldots \ldots \ldots \ldots \ldots \ldots$ A-1

APPENDIX B - WEIGHTED AVERAGING OF CENTERED AND UPWINDED VALUES ................................................... B-1

APPENDIX C - VARIABLE AND SUBROUTINE DICTIONARY ...............C-1

APPENDIX D— SAMPLE INPUT FILE .....................................

\section{FIGURES}

1. Equation of state carve ..................................................... 7

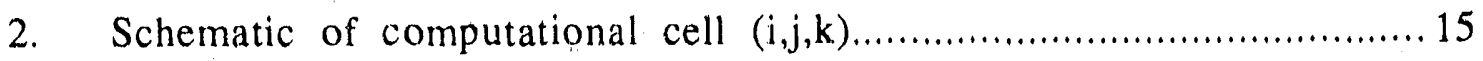

3. $\mathrm{X}-\mathrm{Y}$ cross section of computational region...................................... 15

4. Schematic illustration of a momentum cell ................................ 17

5. Wall boundary orientated along a cell face. ............................. 23

6. Diagonal wall boundary. ................................................ 26

7. Top level flow chart for the MAGMA code............................... 32

8. Subroutine hierarchical table of contents (HTOC)................................... 34

9. Geometry and thermal boundary conditions for test 3 b............................4 45

10. MAGMA steady state velocity vectors for test $3 \mathrm{~b}$ (maximum

11. MAGMA Steady state temperature isotherms for test $3 \mathrm{~b}$

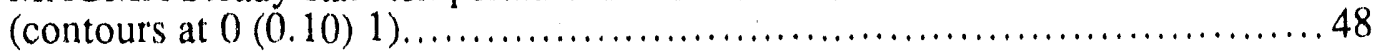

12. Reference 12 steady state temperature isotherms for test $3 \mathrm{~b}$

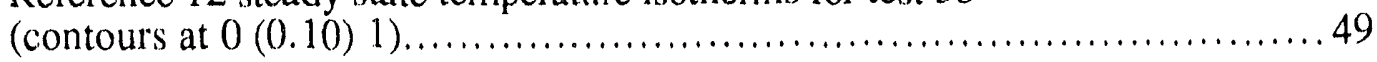

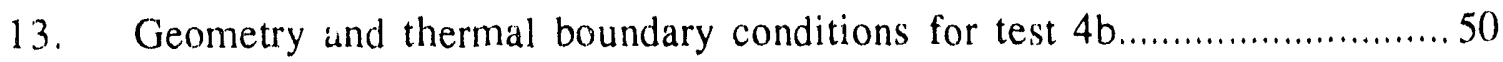

14. MAGMA temperature profiles at mid-height for test 4 a $\ldots \ldots \ldots \ldots \ldots \ldots \ldots \ldots . \ldots \ldots 1$

15. MAGMA vertical velocity profiles at mid-height for test 4 a..........................5. 52

16. Reference 13 steady state temperature profiles at mid-height for test 4 a..........53

17. Reference 13 steady state vertical velocity profiles at mid-height for test $4 a \ldots . .53$ 
18. MAGMA steady state temperature contours at $\mathrm{z} / \mathrm{H}=0.5$ for test $4 \mathrm{a}$ (contours at $0(0.10) 1)$...

19. MAGMA steady state velocity vectors at $\mathrm{z} / \mathrm{H}=0.5$ for tes: $4 \mathrm{a}$ (maximum dimensionless velocity $=36.34$ ),

20. Reference 13 steady state temperature contours at $\mathrm{z} / \mathrm{H}=0.5$ for test $4 \mathrm{a}$ (contours at $0(0.10) 1)$.....

21. Reference 13 steady state velocity vectors at $\mathrm{z} / \mathrm{H}=0.5$ for test $4 \mathrm{a}$ (maximum dimensionless velocity $=43$ ).

22. Geometry and thermal boundary conditions for test 5 .

23. MAGMA melt front profiles versus nondimensional time

24. Reference 14 melt front profiles versus nondimensional time. 60

25. MAGMA velocity vectors at $\tau=0.0983$ for test 5 .

26. MAGMA temperature contours at $\tau=0.0983$ for test 5 (contours at $0(0.10) 1)$.

27. MAGMA calculated transient response of the average Nusselt number. 64

28. Reference 14 calculated transient response of the average Nusselt number. .65

A-1. Four active cells in the $x-y$ plane.

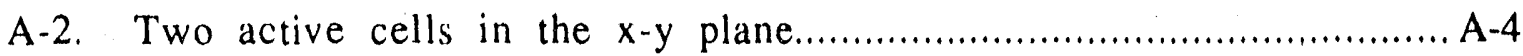

B-1. Two computational cells in the $x-y$ plane..............................

\section{TABLES}

1. Interpretation of temperature boundary condition parameters.................. 38

2. Interpretation of the IFIMP variable flag. ................................ 39

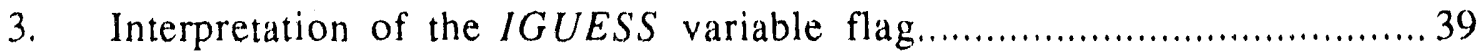

4. Summary of MAGMA test problems. ................................... 42

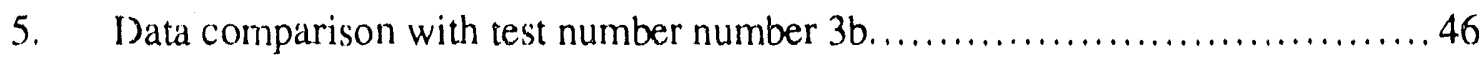

6. Comparison of the transient dimensionless molten volume for test number 5 . 
NOMENCLATURE

a

al

a 2

a 3

a4

$b$

c

$e$

$\mathbf{e}_{\mathbf{x}}$

ey

$\mathbf{e}_{\mathbf{Z}}$

g

h

H

i

j

$k$

$k$

$L$

$L_{C}$

$\mathrm{Nu}$

p

PCM

$\mathrm{Pr}$

$q$

$q^{\prime \prime}$

$R a$

Ste

$T$

Artifictal sound speed

Polynomial coefficient (user input)

Polynomial coefficient (user input)

Polynomial coefficient (user input)

Polynomial coefficient (user input)

Artificial bulk viscosity

Specific heat capacity

Specific energy

Unit vector in $\mathrm{x}$-direction

Unit vector in $y$-direction

Unit vector in z-direction

Gravity vector

Convective heat transfer coefficient

Typical height

Cell index in the $x$-direction

Cell index in the $y$-direction

Cell index in the $z$-direction

Thermal conductivity

Latent heat of fusion

Typical length

Nusselt number

Pressure (divided by density)

Phase Change Material

Prandtl number

Heat generation term

Heat flux

Rayleigh number

Stefan number

Temperature 


$\begin{array}{ll}T_{m} & \text { Melting temperature. } \\ T_{o} & \text { Reference temperature } \\ \mathbf{u} & \text { Velocity Vector } \\ & \\ u & \text { Velocity in x-direction } \\ \mathrm{V} & \text { Volume of a computational cell } \\ v & \text { Velocity in y-direction } \\ w & \text { Velocity in z-direction }\end{array}$

Greek Symbols:

$\alpha$

$\beta$

$\Delta \tau$

$\Delta x$

$\Delta y$

$\Delta z$

$\mathrm{v}$

$\rho$

$\sigma$

$\tau$

$\omega$

$\xi$

$\alpha$

$\varepsilon_{1}$

$\varepsilon_{2}$
Thermal diffusivity $\left(\alpha=\frac{k}{\rho c}\right)$

Coefficient of thermal expansion

Artificial or pseudo-time step

Spatial increment in $x$-direction

Spatial increment in $y$-direction

Spatial increment in z-direction

Kinematic viscosity

Density

Viscous stress tensor

Dimensionless time

Dimensionless damping coefficient of order unity

Cylindrical coordinates flag

Safety factor on the pseudo-time step

$(0<\alpha<1)$

Convergence tolerance on $\nabla \cdot \mathbf{u}$

Convergence tolerance on $\frac{\partial u}{\partial \tau}, \frac{\partial v}{\partial \tau}$, and $\frac{\partial w}{\partial \tau}$

Subscripts:

B

D

$\mathrm{F}$
Bottom side of a computational cell

Derriere side of a computational cell

Front side of a computational cell 
$\mathrm{L}$

R

$\mathrm{T}$

w

$x$

$y$

$z$

$\infty$
Left side of a computational cell

Right side of a computational cell

Top side of a computational cell

Wall value

Value in the $x$-direction

Value in the $y$-direction

Value in the $z$-direction

Value of surroundings at infinity

Superscripts:

(k)

$m_{q}$

$n$

$\nabla$

$(\mathbf{A})^{\mathrm{T}}$

$\max (A), A_{\max }$

$<A>i j k$

(A)
Iteration level

Refers to a particular momentum cell

denoted by $q$ with $q$ equal either to $u, v$, or $w$

Time level

Gradient operator

Transpose of $\mathbf{A}$

Search over all computational cells for

the maximum value of $A$

$\min (A), A_{\min } \quad$ Search over all computational cells for

the minimum value of $A$

Volume average of $A$ over cell $(i, j, k)$

Average value of $A$ 


\section{A COMPUTATIONAL MODEL FOR VISCOUS FLUID FLOW, HEAT TRANSFER, AND MELTING IN IN SITU VITRIFICATION MELT POOLS}

\section{INTRODUCTION}

MAGMA is a finite difference computer code developed to simulate the three dimensional viscous fluid flow and heat transfer within in situ vitrification (ISV) melt pools. The starting point for the development of MAGMA was an experimental, fully implicit, two-dimensional, incompressible flow, computer code. ${ }^{a}$

The objective of this work was to devise, implement, and test the code modifications needed to permit three-dimensional simulations of melt flow in partially molten domains with curved boundaries. The tasks completed in achieving this objective include:

- The development of boundary condition logic for walls that pass diagonally through cell faces in two dimensions.

- Implementing and testing the two-dimensional diagonal boundary condition logic.

- Converting from direct to indirect, addressing to facilitate limiting calculation of fluid flow to the molten part of the domain.

- The addition of three-dimensional capability.

- A code generalization to allow for variable properties.

- Implementing the Boussinesq buoyancy force terms in the momentum equation. ${ }^{1}$

- Implementing an explicit, finite difference solution of the energy equation.

- A code generalization to allow cell melting, freezing, and the simulation of latent heat effects.

a. Unpublished research results of J. D. Ramshaw and P.R. McHugh, entitled "Hybrid Iteration Scheme for Implicit Calculations of Incompressible Flow." 
The purpose of this report is to document the MAGMA code so that it can serve as a guide for code use, and as a reference source if code modifications are required in the future. Therefore, it includes descriptions of: the basic governing equations and numerics, the finite difference mesh, boundary condition implementation, code structure, code input and output, and code options.

The report is organized into five main sections. The following section describes the basic governing equations, the computational mesh, the basic differencing scheme, and boundary condition implementation. Section 3 is concerned with code structure and organization, code input and output, and code options. Section 4 describes code verification and testing. The final section contains a summary, and recommendations for further code development. 


\section{GOVERNING EQUATIONS AND NUMERICS}

This section describes MAGMA's basic governing partial differential equations and summarizes the numerical techniques used to solve these equations. Included in this discussion are: descriptions of the three-dimensional finite difference mesh, differencing schemes, and boundary condition implementation.

\subsection{Governing Equations}

The governing equations used by MAGMA are the conservation equations for incompressible viscous flow and heat transfer in three spatial dimensions. The couping between the momentum and energy equations occurs through the buoyancy force term in the momentum equation, using the Boussinesq approximation. ${ }^{1}$

\subsubsection{Incompressible Navier-Stokes Equations}

Fluid flow is governed by the incompressible Navier-Stokes equations, namely

$\nabla \cdot \mathbf{u}=0$

$\frac{\partial \mathbf{u}}{\partial t}+\nabla \cdot(\mathbf{u u})=-\nabla p-\beta \mathbf{g}\left(T-T_{O}\right)+\nabla \cdot \sigma$

where the viscous stress tensor, $\sigma$, is given by,

$\sigma=v\left((\nabla \mathbf{u})+(\nabla \mathbf{u})^{\mathrm{T}}\right)$

where

$\mathbf{g} \quad=\quad$ gravity vector
$p \quad=\quad$ pressure (divided by density)
$T \quad=$ temperature
$T_{O}=$ reference temperature




$$
\begin{array}{ll}
\mathbf{u} & =\text { velocity vector } \\
\beta \quad & =\text { coefficient of thermal expansion } \\
v & =\text { kinematic viscosity } \\
\nabla & =\text { vector gradient operator }
\end{array}
$$
$(\mathbf{A})^{\mathrm{T}}=$
transpose of A.

MAGMA allows the use of two and three-dimensional rectangular coordinates, and twodimensional cylindrical coordinates. When the two-dimensional option is invoked, all terms associated with the $z$-coordinate vanish. Two-dimensional cylindrical coordinates take the $y$-axis as the axis of symmetry, and the $x$-coordinate as the radial coordinate. Equations (4) through (7) below, are Equations (1) through (3) expressed in terms of coordinates and velocity components. $\xi=1$ corresponds to two-dimensional cylindrical coordinates, while $\xi=0$ corresponds to rectangular coordinates.

- Continuity equation:

$\frac{\partial u}{\partial x}+\frac{\partial v}{\partial y}+\frac{\partial w}{\partial z}+\xi \frac{u}{x}=0$

- Momentum equation in $\mathrm{x}$-direction:

$$
\begin{gathered}
\frac{\partial v}{\partial t}+\frac{\partial u^{2}}{\partial x}+\frac{\partial u v}{\partial y}+\frac{\partial u w}{\partial z}+\xi \frac{u^{2}}{x}=-\frac{\partial p}{\partial x}-\beta\left(\mathbf{g} \cdot \mathbf{e}_{\mathbf{x}}\right)\left(T-T_{o}\right) \\
+\frac{1}{x^{\xi}} \nabla \cdot\left(x^{\xi} \sigma_{\mathbf{x}}\right)-\left(\frac{2 \xi v v}{x^{2}}\right)
\end{gathered}
$$


- Momentum equation in y-direction

$$
\begin{gathered}
\frac{\partial v}{\partial t}+\frac{\partial u v}{\partial x}+\frac{\partial v^{2}}{\partial y}+\frac{\partial v w}{\partial z}+\xi \frac{u v}{x}=-\frac{\partial p}{\partial y}-\beta\left(\mathbf{g} \cdot \mathbf{e}_{\mathbf{y}}\right)\left(T-T_{o}\right) \\
+\frac{1}{x^{\xi}} \nabla \cdot\left(x^{\xi} \sigma_{\mathbf{y}}\right)
\end{gathered}
$$

- Momentum equation in z-direction (not used when $\xi=1$ )

$\frac{\partial w}{\partial t}+\frac{\partial u w}{\partial x}+\frac{\partial v w}{\partial y}+\frac{\partial w^{2}}{\partial z}=-\frac{\partial p}{\partial z}-\beta\left(\mathbf{g} \cdot \mathbf{e}_{\mathbf{z}}\right)\left(T-T_{O}\right)+\nabla \cdot\left(\sigma_{\mathbf{z}}\right)$

where

$$
\begin{aligned}
& \sigma_{\mathbf{x}}=\sigma \cdot \mathbf{e}_{\mathbf{x}}=v \quad\left(\nabla u+\frac{\partial \mathbf{u}}{\partial x}\right) \\
& \sigma_{\mathbf{y}}=\sigma \cdot \mathbf{e}_{\mathbf{y}}=v \quad\left(\nabla v+\frac{\partial \mathbf{u}}{\partial y}\right) \\
& \sigma_{\mathbf{z}}=\sigma \cdot \mathbf{e}_{\mathbf{z}}=v\left(\nabla w+\frac{\partial \mathbf{u}}{\partial z}\right)
\end{aligned}
$$

where

$$
\begin{aligned}
& \mathbf{e}_{\mathrm{x}}=\text { unit vector in } \mathrm{x} \text {-direction } \\
& \text { ey }=\text { unit vector in } y \text {-direction } \\
& \mathbf{e}_{\mathbf{z}}=\text { unit vector in } \mathrm{z} \text {-direction } \\
& u=x \text {-component of } u \\
& v=y \text {-component of } \mathbf{u} \\
& w=\quad \mathbf{z} \text {-component of } \mathbf{u} \text {. }
\end{aligned}
$$


Note that the vector gradient operator $\nabla$ in Equations (4) through (10), is defined as

$$
\nabla=\mathbf{e}_{\mathbf{x}} \frac{\partial}{\partial x}+\mathbf{e}_{\mathbf{y}} \frac{\partial}{\partial y}+\mathbf{e}_{\mathbf{z}} \frac{\partial}{\partial z}
$$

with the understanding that the $\mathrm{z}$-component vanishes in two-dimensions. This convention is used even in the cylindrical case. Thus divergences in Equations (4) through (10) represent the Euclidean divergence, not covariant divergence.

\subsubsection{Energy Equation}

The energy conservation equation, which governs heat transfer, is given by

$\rho\left(\frac{\partial e}{\partial t}+\nabla \cdot(e \mathbf{u})\right)=\nabla \cdot(k \nabla T)+q$

where

$$
\begin{aligned}
e \quad & \text { specific energy } \\
k & =\text { thermal conductivity } \\
q & =\text { heat generation } \\
\rho & =\text { density. }
\end{aligned}
$$

Viscous dissipation due to viscosity has been neglected, as it is negligible in incompressible flow.

In terms of the spatial coordinates, Equation (12) becomes

$$
\begin{gathered}
\rho\left(\frac{\partial e}{\partial t}+\frac{\partial(u e)}{\partial x}+\frac{\partial(v e)}{\partial y}+\frac{\partial(w e)}{\partial z}+\xi \frac{e u}{x}\right)=\frac{\partial}{\partial x}\left(k \frac{\partial T}{\delta x}\right) \\
+\frac{\partial}{\partial y}\left(k \frac{\partial T}{\partial y}\right)+\frac{\partial}{\partial z}\left(k \frac{\partial T}{\partial z}\right)+\xi \frac{k}{x} \frac{\partial T}{\partial x}+q .
\end{gathered}
$$

Terms associated with the $z$-coordinate vanish in two-dimensions. 


\subsubsection{State Relation and Melting Model}

An equation of state is used to relate cell energies to cell temperatures. This state equation accounts for latent heat effects, and allows user modification for use with different types of fluids. The form of the state relation is illustrated in Figure 1. Note that the zero of energy has arbitrarily been taken to be the energy of the solid phase at the melting point. For $e<0$ and $e>L$, the curve is assumed to obey a quadratic relation of the form

$e=\left[\begin{array}{ll}a 1\left(T-T_{m}\right)+a 2\left(T-T_{m}\right)^{2} & , \quad e<0 \\ L+a 3\left(T-T_{m}\right)+a 4\left(T-T_{m}\right)^{2}, & e>L\end{array}\right]$

where the coefficients $a 1, a 2, a 3$, and $a 4$ are user input numbers, and

$L \quad=\quad$ latent heat of fusion

$T_{m}=$ melting temperature.

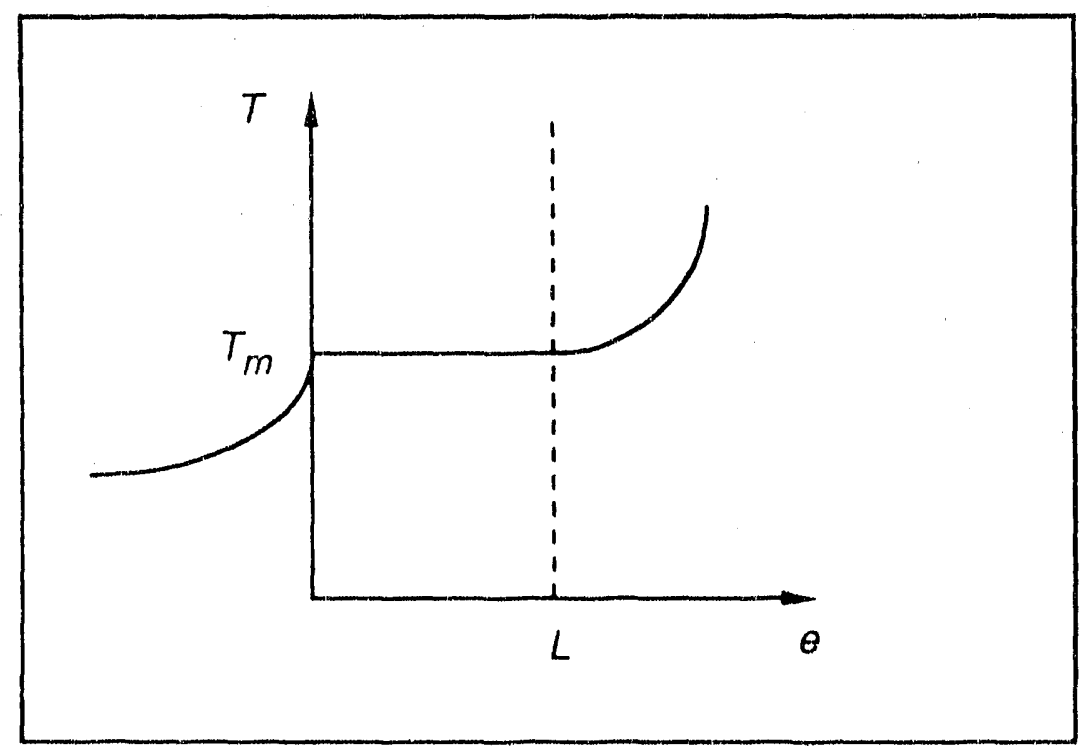

Figure 1. Equation of state curve.

For $0<e<L$, the temperature remains constant and is equal to the melt temperature of the fluid, $T_{m}$. 
If the curves are linear for $e<0$ ) and $e>L$ (i.e., $a 2=a 4=0$ ), then $a l$ is the specific heat of the solid phase $(e<0)$ and $a 3$ is the specific heat of the liquid phase $(e>L)$ of the material. If $L=$ $a 1=a 2=a 4=0$ and $a 3$ is the specific heat of the material, Equation (13) reduces to the temperaiure equation in the absence of phase change.

A cell $(i, j, k)$ is assumed to be solid when $e<0$. Partial melting occurs when $0<e<L$, and complete melting when $\mathrm{e}>\mathrm{L}$. Presently, MAGMA does not allow for partially molten cells. Thus, the condition $e>L / 2$ was chosen as the criterion for cell melting. If the cell energy of a solid cell rises above $L / 2$, the cell melts. Conversely, if the cell energy of a molten cell falls below $L / 2$, it solidifies.

MAGMA assumes that all fluid properties, except density, are variable (density is allowed to vary only in the buoyancy force term in the momentum equation through the Boussinesq approximation). ${ }^{1}$ If fluid properties are allowed to vary, relations describing this behavior or specific property data must be supplied by the user. 


\subsection{Temporal Differencing and Time Integration Procedure}

This section describes the time integration techniques and the temporal differencing scheme for the governing equations presented in Section 2.1. The solution procedures of the incompressible Navier-Stokes equations and the energy equation are treated separately in the sections that follow.

First-order forward differences are used to approximate all time derivatives. The time differencing is performed with respect to a set of discrete time values $t^{n}$ separated by a variable time increment, $\Delta t=t^{\mathrm{n}+1}$ - $t^{\mathrm{n}}$. The time level $n$ is used as a superscript to denote the time level of a quantity $q$. Thus, $q^{\mathrm{n}}$ is the finite difference approximation to the quantity $q$ at time $t^{\mathrm{n}}$.

In the following sections, the temporal differencing scheme is illustrated while spatial differencing is suppressed for clarity. Note that all spatial derivatives should be replaced with their finite difference approximations as described in Section 2.3.

\subsubsection{Incompressible Navier-Stokes Equations}

The code solves a fully implicit time discretization of the incompressible Navier-Stokes equations, namely

$$
\begin{aligned}
& \nabla \cdot \mathbf{u}^{\mathrm{n}+1}=0 \\
& \frac{\mathbf{u}^{\mathrm{n}+1}-\mathbf{u}^{\mathrm{n}}}{\Delta t}+(\nabla \cdot(\mathbf{u u}))^{\mathrm{n}+1}=-\nabla p^{\mathrm{n}+1}-\beta \mathbf{g}\left(T^{\mathrm{n}+1}-T_{o}\right)+\nabla \cdot \sigma^{\mathrm{n}+1} .
\end{aligned}
$$

The scheme of Equations (15) and (16) constitutes a nonlinear algebraic system of equations for the advanced-time quantities $\mathrm{p}^{\mathrm{n}+1}$ and $\mathbf{u}^{\mathrm{n}+1}$. This system is solved by a new hybrid iteration schemea which is essentially a generalization of the damped artificial compressibility method for steady-state incompressible flow ${ }^{3}$ to the fully implicit transient equations. This scheme may be written in the form

a. Unpublished research results of J. D. Ramshaw and P. R. McHugh entitled "Hybrid Iteration Scheme for Implicit Calculations of Incompressible Flow." 


$$
\begin{aligned}
& \frac{e^{(\mathrm{k}+1)}-p^{(\mathrm{k})}}{\Delta t}=-a^{2} \nabla \cdot \mathbf{u}^{(\mathrm{k})} \\
& \frac{\mathbf{u}^{(\mathrm{k}+1)}-\mathbf{u}^{(\mathrm{k})}}{\Delta t}+\frac{\mathbf{u}^{(\mathrm{k}+1)}-\mathbf{u}^{\mathrm{n}}}{\Delta t}=-(\nabla \cdot(\mathbf{u u}))^{(\mathrm{k})} \cdot \nabla\left(p^{(\mathrm{k}+1)}-b \nabla \cdot \mathbf{u}^{(\mathrm{k})}\right) \\
& -\beta \mathrm{g}\left(T^{\mathrm{n}+1}-T_{o}\right)+\nabla \cdot \sigma^{(\mathrm{k})}
\end{aligned}
$$

where $\mathrm{q}^{(\mathrm{k})}$ denotes the approximation to $\mathrm{q}^{\mathrm{n}+1}$ after the $\mathrm{k}^{\text {th }}$ iteration. The parameter $a$ is an artificial sound speed, $b$ is an artificial bulk viscosity, and $\Delta \tau$ is the artificial or pseudo-time step. These parameters are constrained by the stability restrictions

$$
\begin{aligned}
& \frac{2 v \Delta \tau}{\Delta^{2}}-\frac{\Delta \tau}{2 \Delta \tau}<1 \\
& \frac{\Delta \tau\left(\alpha^{2} \Delta \tau+2 b+2 v\right)}{\Delta^{2}}-\frac{\Delta \tau}{2 \Delta t}<1 \\
& b+v+\frac{\Delta^{2}}{4 \Delta t}>0
\end{aligned}
$$

where

$$
\Delta^{2}=\left\{\frac{1}{\Delta x^{2}}+\frac{1}{\Delta y^{2}}+\frac{1}{\Delta z^{2}}\right\}^{-1} .
$$

Here $\Delta x, \Delta y$, and $\Delta z$ are the spatial increments in the $x-, y_{-}$, and $z$-directions respectively, with the understanding that $\Delta z=\infty$ in two dimensions. Notice that $b$ itself need not be positive. These results were derived by a linear stability analysis of the differenced equations neglecting the convection terms. The latter impose an additional material Courant restriction on $\Delta \tau$ of the form

$\Delta \tau<\min \left\{\frac{\Delta x}{|\downarrow|}, \frac{\Delta y}{|v|}, \frac{\Delta z}{|w|}\right\}$

where $u, v$, and $w$ are respectively the $x-, y_{-}$, and $z$-components of $\mathbf{u}$, and the min operation includes a search over all cells in the computing mesh. In the derivation of the stability restrictions, 
$v$ was assumed constant in the continuous equations, resulting in considerable simplification of the viscous terms. If $v$ is assumed variable, then additional terms arise which make the stability conditions more restrictive by replacing $v$ with $2 v$ in Equations (20) and (21).

The proper selection of the parameters is somewhat more difficult than in the analogous steady-state method, ${ }^{4}$ because the character and behavior of the system now depend on the additional parameter $\Delta t$. In particular, care must be taken to ensure that the hyperbolic character of the system is not lost due to the additional damping introduced by the time derivative terms. This consideration, together with an analysis of the net damping rate, leads to the expressions ${ }^{b}$

$a^{2}=\frac{1.1}{4}\left(\frac{L_{c}^{2}}{\pi^{2} \Delta t^{2}}+\frac{\pi^{2} v^{2}}{L_{c}^{2}}+\frac{2 v}{\Delta t}\right)$

$\Delta \tau=\alpha\left\{\min \left\{\left[\frac{2 v}{\Delta^{2}}-\frac{1}{2 \Delta t}\right]^{-1}, \Delta \tau^{*}\right\}, \quad \begin{array}{c}\Delta t>\Delta^{2} /(4 v) \\ \Delta \tau^{*}, \quad \Delta t<\Delta^{2} /(4 v)\end{array}\right\}$

$b=\frac{\Delta^{2}}{4 \Delta t}\left[2 \omega\left(1+\frac{\Delta t}{\Delta \tau}\right)-1\right]-a^{2} \Delta \tau-v$

where

$$
\Delta \tau^{*}=\frac{\omega \Delta^{2}}{4 a^{2} \Delta t}\left[1+\left(1+\frac{8 a^{2} \Delta t^{2}}{\omega \Delta^{2}}\right)^{\frac{1}{2}}\right]
$$

$L_{C}$ is a length typical of the overall dimensions of the flow region, $\alpha$ is a safety factor on the pseudo-time step $(0<\alpha<1)$, and $\omega$ is a dimensionless damping coefficient of order unity. For Reynolds numbers near 0.1 the values $\alpha=0.9$ and $\omega=0.124$ appear to be nearly optimal. At higher Reynolds numbers smaller values of $\alpha$ are needed to ensure compliance with the convective stability limit of Equation (23).

b. Unpublished research results of J. D. Ramshaw and P. R. McHugh entitled "Hybrid Iteration Scheme for Implicit Calculations of Incompressible Flow. 
The scheme must also be supplemented by convergence criteria to determine when the iteration has converged to satisfactory accuracy. At present these criteria are taken to be

$\max \left|\nabla \cdot \mathbf{u}^{(\mathrm{k}+1)}\right|<\varepsilon_{1} \frac{|\mathbf{u}|_{\max }}{L_{C}}$

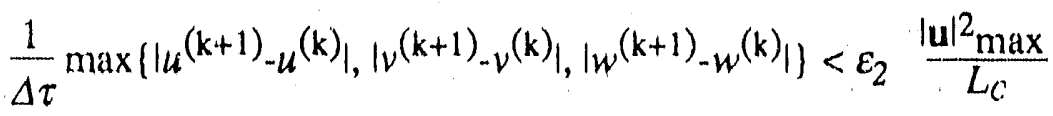

where the max operations include a search over all cells in the computing mesh. We currently take $\varepsilon_{1}=10^{-5}$ and $\varepsilon_{2}=10^{-3}$.

MAGMA also allows a linearly implicit option in the temporal differencing of the convection terms. This option consists of linearizing the convective terms by replacing $\nabla \cdot(\mathbf{u u})^{(\mathrm{k})}$ in Equation (18) with $\nabla \cdot\left(\mathbf{u}^{\mathrm{n}} \mathbf{u}^{(\mathrm{k})}\right)$, where $n$ is the time level and $k$ is the iterate level. In addition, a semi-implicit solution algorithm can be invoked by evaluating all te rms on the right hand side of Equation (18) except pressure and temperature at the old time value, $n$.

\section{2,2 Energy Equation}

The code solves an explicit time discretization of the energy conservation equation,

$\rho\left(\frac{e^{\mathrm{n}+1}-e^{\mathrm{n}}}{\Delta t}+\nabla \cdot(\mathbf{u} e)^{\mathrm{n}}\right)=\nabla \cdot(k \nabla T)^{\mathrm{n}}+q$

Cell energies are marched forward explicitly in time to the new time level using only variables from the previous time level. The time step is therefore limited by the diffusive and Courant stability restrictions,

$\Delta t<\frac{\Delta^{2}}{2 \alpha}$

$\Delta t<\min \left\{\frac{\Delta x}{|u|}, \frac{\Delta y}{|v|}, \frac{\Delta z}{|w|}\right\}$ 
where

$$
\alpha=\frac{k}{\rho c} \text { (thermal diffusivity) }
$$

and $c$ is the specific heat capacity. If necessary, the code resets $\Delta t$ after each time step in order to satisfy the changing Courant stability restriction.

It would of course be preferable to use a fully implicit scheme for the energy equation as well, thereby removing the stability restrictions of Equations (31) and (32). This scheme should be replaced by a fully implicit scheme if the model is developed further. 


\subsection{Spatial Differencing}

The governing equations are spatially differenced using the control volume or finite volume approach, whereby the temporally differenced conservation equations are averaged over the volume of the appropriate computational cell. 4 The divergence theorem is used to convert the volume averages of terms of divergence form to surface integrals over cell faces. This procedure leads to conservative difference equations for mass, momentum, and energy. ${ }^{4}$ The spatial differencing is conventional in all respects. All terms other than convection are approximated by centered differences, while convection terms are approximated by weighted averages of centered and upwind (donor cell) differences (see Appendix B).

\subsubsection{Finite Difference Mesh}

MAGMA numerically solves differenced forms of the coupled governing equations on a two- or three-dimensional, staggered grid using two- or three-dimensional rectangular coordinates or two-dimensional cylindrical coordinates. The computational mesh consists of rectangular cells of width $\Delta x$, length $\Delta y$, and height $\Delta z$. The mesh contains imax cells in the $x$-direction, jmax cells in the $y$-direction, and kmax cells in the $z$-direction.

Variables in a computational cell are placed according to the MAC solution procedure. ${ }^{2}$ Velocity components are located on cell faces, while pressures, temperatures, energies, and fluid properties are located at cell centers. Figure 2 is a schematic illustration of a computational cell. Note the terminology used in this figure to refer to cell faces. For example, the velocity component in the $x$-direction $(u)$ is located on the right cell face, the $y$-direction velocity component $(v)$ on the front cell face, and the $z$-direction velocity component $(w)$ on the top cell face. The cell faces opposing these three sides are the left, derriere, and bottom cell faces, respectively. The mesh contains both active cells containing fluid and inactive solid cells, as shown in Figure 3. Cells not containing fluid (inactive cells) are represented by shaded cells. Boundary cells are used to impose the velocity and temperature boundary conditions. Velocity boundary cells, which are marked with the letters $V B C$ in Figure 3, are always adjacent to cells that contain fluid. Temperature boundary cells, which are marked with the letters $T B C$ in Figure 3, are always located at the edges, or perimeter, of the computational region. Three-dimensional rectangular coordinates is the code default. Two-dimensional rectangular coordinates and two-dimensional cylindrical coordinates are invoked by setting the spatial increment in the $z$-direction to a negative value $(\Delta z<0)$. This option forces all terms associated with the $z$-coordinate to vanish in the discretized form of the governing equations (formally $\Delta z \rightarrow \infty$ ). Two-dimensional cylindrical coordinates assume that the 


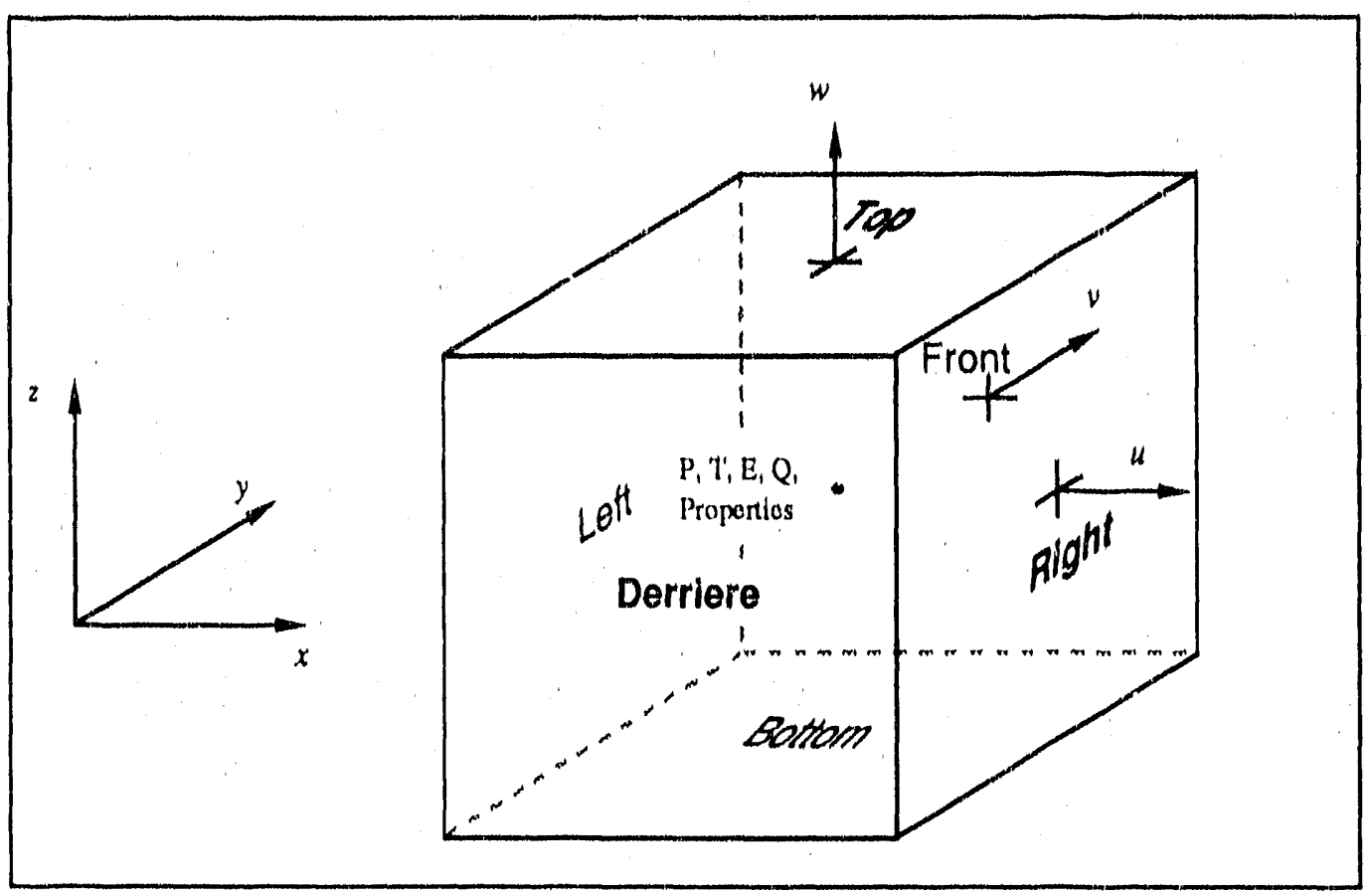

Figure 2. Schematic of computational cell $(i, j, k)$.

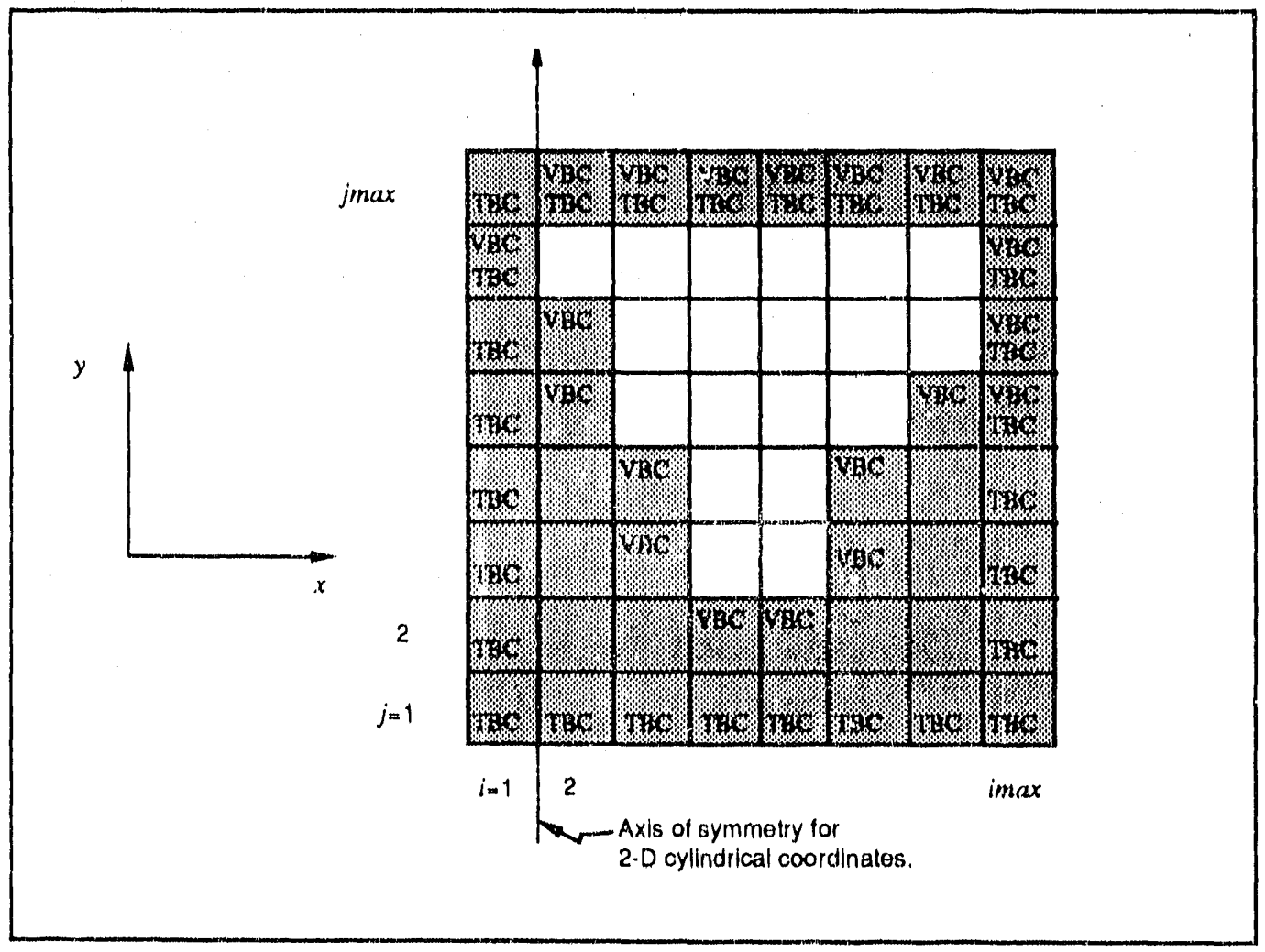

Figure 3. $X-y$ cross section of computational region. 
$y$-coordinate axis is the axis of symmetry, $x$ is the radial coordinate, and all terms associated with the $z$-coordinate vanish. These cylindrical terms in the governing equations are included in the formulation when the cylindrical coordinates flag, $\xi$ (CYL in the code), is set to one.

Cell spacing in all coordinate directions is assumed uniform. Simple averaging is used to obtain quantities at points on the mesh where they are not explicitly defined. The averaging procedure is described in Appendix A.

As shown in Figure 2, velocities are located on cell faces, i.e.,

$u_{i j k}=u\left(i \Delta x,\left(j-\frac{1}{2}\right) \Delta y,\left(k-\frac{1}{2}\right) \Delta z\right)$

$\left.v_{i j k}=v\left[\left(i-\frac{1}{2}\right) \Delta x, j \Delta y,\left(k-\frac{1}{2}\right) \Delta z\right)\right]$

$\left.w_{i j k}=w\left[\left(i-\frac{1}{2}\right) \Delta x,\left(j-\frac{1}{2}\right) \Delta y, k \Delta z\right)\right]$

All other quantities are located at cell centers. The location of the cell centered quantity $Q_{i j k}$, is given by

$\left.Q_{i j k}=Q\left[\left(i-\frac{1}{2}\right) \Delta x,\left(j-\frac{1}{2}\right) \Delta y,\left(k-\frac{1}{2}\right) \Delta z\right)\right]$

The volume, $V$, of a computational cell $(i, j, k)$ is simply,

$V=\Delta x \Delta y \Delta z$

It is convenient to define three additional types of cells, called momentum cells, which are centered about the locations of the velocity components. Figure 4 illustrates the momentum cell corresponding to the $u$-velocity component. Analogous momentum cells exist for the $v$ and $w$ velocity components. In the notation of subsequent sections, the momentum cells corresponding to the $u_{-}, v-$, and $w$-velocity components are referred to by superscripts $m_{u}, m_{V}$, and $m_{W}$ respectively. 


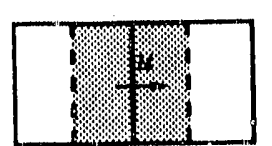

$(i, j, k)$

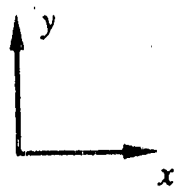

Shaded region is the momenum cell for the $u$-velocity component

Figure 4. Schematic illustration of a momentum cell corresponding to the $u$-velocity component.

\subsubsection{Differencing Notation}

Following the notation of Reference 4, volume averages are denoted by angle brackets. The average of a quantity, $Q$, over a typical cell $(i, j, k)$ is given by

$<Q>_{i j k}=\frac{1}{V} \iiint Q(x, y, z) d x d y d z$

where the volume integral is taken over that cell. Similarly, the average of a quantity over each of the three momentum cells is denoted by

$<Q>_{i j k}^{m_{u}}=\frac{1}{V} \iiint Q(x, y, z) d x d y d z$

$<Q>_{i j k}^{m_{\nu}}=\frac{1}{V} \iiint Q(x, y, z) d x d y d z$

$<Q>_{i i k}^{m_{W}}=\frac{1}{V} \iiint Q(x, y, z) d x d y d z$ 
where the volume integrals are taken over the indicated momentum cell. If the quantity $Q$ is not of divergence form, these averages are approximated by the values at cell centers; i.e.,

$<Q>_{i j k}=Q\left(\left(i-\frac{1}{2}\right) \Delta x,\left(j-\frac{1}{2}\right) \Delta y,\left(k-\frac{1}{2}\right) \Delta z\right)$

$<Q>i j k=Q\left(i \Delta x,\left(j-\frac{1}{2}\right) \Delta y,\left(k-\frac{1}{2}\right) \Delta z\right)$

$\left.<Q>_{i j k}^{m_{v}}=Q\left(\left(i-\frac{1}{2}\right) \Delta x, j \Delta y,\left(k-\frac{1}{2}\right) \Delta z\right)\right)$

$\left.<Q>_{i j k}^{m_{W}}=Q\left(\left(i-\frac{1}{2}\right) \Delta x,\left(j-\frac{1}{2}\right) \Delta y, k \Delta z\right)\right)$

where the quantity $Q(x, y, z)$ is evaluated at the point $(x, y, z)$ using whatever averaging is necessary. The averaging procedure used by MAGMA is described in Appendix A.

If the quantity $Q$ is of divergence form, i.e., $Q=\nabla \cdot \mathrm{w}$, where $\mathrm{w}$ is a vector or tensor quantity, then the volume integrals in Equations (39) through (42) are converted to surface integrals using the divergence theorem,

$<\nabla \cdot \mathrm{w}>_{i j k}=\frac{1}{V} \oint_{d A \mathrm{n} \cdot \mathrm{w}}$

where $\mathbf{n}$ is the outward unit normal to the surface and $\oint_{d A}$ is the surface integral over that surface. Equation (47) can be approximated by

$\langle\nabla \cdot \mathbf{W}\rangle_{i j k}=\frac{1}{V} \sum_{\alpha}(\Delta A \mathbf{n})_{\alpha} \cdot \mathbf{w}_{\alpha}$ 
where the subscript a refers to the faces of the cell $(i, j, k)$. Equation $(48)$ can be expanded as

$$
\begin{aligned}
<\nabla \cdot \mathrm{W}>_{i j k}= & \frac{1}{V}\left[(\Delta A \mathbf{n})_{\mathrm{B}} \cdot \mathrm{W}_{\mathrm{B}}+(\Delta A \mathbf{n})_{\mathrm{D}} \cdot \mathrm{W}_{\mathrm{D}}\right. \\
& +(\Delta A \mathbf{n})_{\mathrm{F}^{*}} \cdot \mathrm{W}_{\mathrm{F}}+(\Delta A \mathbf{n})_{\mathrm{L}} \cdot \mathrm{W}_{\mathrm{L}} \\
& \left.+(\Delta A \mathbf{n})_{\mathrm{R}} \cdot \mathrm{W}_{\mathrm{R}}+(\Delta A \mathbf{n})_{\mathrm{T}} \cdot \mathrm{W}_{\mathrm{T}}\right]
\end{aligned}
$$

where the subscripts B, D, F, L, R, and T refer to the bottom, derriere, front, left, right, and top sides, respectively, of the computational cell $(i, j, k)$. The quantities in parentheses in Equation (49) are defined as follows:

$(\Delta A \mathbf{n})_{\mathrm{B}}=-\mathbf{e}_{\mathrm{z}} \Delta x \Delta y$

$(\Delta A \mathbf{n})_{D}=-\mathbf{e}_{\mathbf{y}} \Delta x \Delta z$

$(\Delta A \mathbf{n})_{F}=\mathbf{e}_{\mathbf{y}} \Delta x \Delta z$

$(\Delta A \mathbf{n})_{L}=-\mathbf{e}_{\mathbf{x}} \Delta y \Delta z$

$(\Delta A \mathbf{n})_{\mathrm{R}}=\mathbf{e}_{\mathbf{x}} \Delta y \Delta z$

$(\Delta A \mathbf{n})_{\mathrm{T}}=\mathbf{e}_{\mathrm{z}} \Delta x \Delta y$

where $\mathbf{e}_{\mathrm{x}}, \mathbf{e}_{\mathrm{y}}$, and $\mathbf{e}_{\mathrm{z}}$ are unit vectors in the $x, y$, and $z$ coordinate directions, respectively. Similar expressions hold for the volume averaged quantities integrated over the three momentum cells. In summation form these expressions are given by

$<\nabla \cdot \mathbf{w}>_{i j k}^{m_{q}}=\frac{1}{V} \sum_{\alpha_{q}}(\Delta A \mathbf{n})_{\alpha_{q}} \cdot \mathbf{w}_{\alpha_{q}}$

where the subscript $\alpha_{q}\left(\alpha_{q}=B, D, F, L, R\right.$, or T $)$ refers to the faces of the momentum cell denoted by $m_{q}$, with $q$ equal to $u, v$, or $w$. 
A special case arises when $Q$ represents convective terms in either the momentum equation or the energy equation (i.e., $Q=\nabla \cdot[\mathbf{u u}]$ or $Q=\nabla \cdot \mid \mathbf{u} T]$ ). As an example, let $Q=\nabla \cdot[\mathbf{u} S]$ where $S$ is the quantity being convected by the velocity, $\mathbf{u}$. The volume averaged expression for $Q$ is given by

$<\nabla \cdot|\mathbf{u} S|>_{i j k}=\frac{1}{V} \sum_{\alpha_{q}}(\Delta A \mathbf{n})_{\alpha_{q}} \cdot S_{a}$

Note that if $S=T$, the summation is performed over the regular cell $(i, j, k)$; however, if $S=u, v$, or $w$, the summation is performed over the corresponding momentum cell $m_{q}$ with $q=u, v$, or $w$. A differencing technique based on a weighted average of centered and donor cell differencing is used in conjunction with the convection terms to ensure numerical stability. The value of $(\Delta A \mathbf{n} \cdot \mathbf{u})_{\alpha_{q}}$ is computed as a centered average on side $\alpha$, while the quantity being convected, $S_{\alpha}$, is computed as a weighted average of its centered and its "upwinded" values as described in Appendix B.

\subsubsection{Incompressible Navier-Stokes Equations}

The spatial differencing for Equations (17) and (18) is given below, using the expanded forms of the equations in the $x-, y-$, and $z$-coordinate directions. The additional terms required for two-dimensional cylindrical coordinates are explicitly included in this discussion. Recall that terms issociated with the $\mathrm{z}$-coordinate direction vanish in two dimensions.

- Continuity equation

$$
\frac{p_{i j k}^{(\mathrm{k}+1)}-p_{i j k}^{(\mathrm{k})}}{\Delta \tau}=-a^{2}\left[\left\langle\nabla \cdot \mathbf{u}^{(\mathrm{k})}\right\rangle_{i j k}+\xi \frac{\left\langle u^{(\mathrm{k})}\right\rangle_{i j k}}{(\mathrm{i}-1 / 2) \Delta x}\right]
$$


- Momentum equation in $\mathrm{x}$-direction

$$
\begin{aligned}
\frac{u_{i j k}^{(\mathrm{k}+1)}-u_{i j k}^{(\mathrm{k})}}{\Delta \tau}= & -\frac{u_{i j k}^{(\mathrm{k}+1)}-u_{i j k}^{\mathrm{n}}}{\Delta t}-\left\langle\nabla \cdot[\mathbf{u} u]^{(\mathrm{k})}>_{i j k}^{m_{i} u}-\xi \frac{<u^{2}>_{i j k}^{m_{u}}}{i \Delta x}\right. \\
& -<\nabla \cdot\left[\mathbf{e}_{\mathbf{x}}\left(p^{(\mathrm{k})}-b<\nabla \cdot \mathbf{u}^{(\mathrm{k})}>_{i j k}\right)\right]>_{i j k}^{m_{u}} \\
& -\beta\left(\mathbf{g} \cdot \mathbf{e}_{\mathbf{x}}\right)<T^{\mathrm{n}+1}-T_{0}>_{i j k}^{m_{u}}+\frac{<\nabla \cdot\left((x)^{\xi} \sigma_{\mathbf{x}}\right)>m_{u}}{(i \Delta x)^{\xi}} \\
& \frac{2 v \xi<u^{2}>m_{i j k}}{(i \Delta x)^{2}}
\end{aligned}
$$

- Momentum equation in y-direction

$$
\begin{aligned}
& \frac{v_{i j k}^{(\mathrm{k}+1)}-v_{i j k}^{(\mathrm{k})}}{\Delta \tau}=-\frac{v_{i j k}^{(\mathrm{k}+1)}-v_{i j k}^{\mathrm{n}}}{\Delta t}-<\nabla \cdot[\mathbf{u} v]^{(\mathrm{k})}>m_{i j k}^{m_{\nu}}-\frac{\xi u \nu>_{i j k}^{m_{\nu}}}{(i-1 / 2) \Delta x} \\
& -<\nabla \cdot\left[e_{y}\left(p^{(k)}-b<\nabla \cdot \mathbf{u}^{(k)}>_{i j k}\right)\right]>_{i j k}^{m_{\nu}} \\
& -\beta\left(\mathbf{g} \cdot \mathrm{e}_{\mathrm{y}}\right)<T^{\mathrm{n+1}}-T_{0}>_{i j k}^{m_{\nu}} \\
& +\frac{\left\langle\nabla \cdot\left((x)^{\xi} \sigma_{y}\right)>m_{\nu}^{m_{\nu}}\right.}{((i-1 / 2) \Delta x)^{\xi}}
\end{aligned}
$$


- Momentum equation in z-direction

$$
\begin{aligned}
& \frac{w^{(k+1)}-w_{i j k}^{(k)}}{\Delta \tau}=\frac{w^{(k+1)}-w_{i j k}^{n}}{\Delta t}-\left\langle\nabla \cdot|\mathbf{u} w|^{(k)}\right\rangle_{i j k}^{m_{w}} \\
& -<\nabla \cdot\left[\mathbf{e}_{\mathbf{z}}\left(p^{(\mathrm{k})}-b\left\langle\nabla \cdot \mathbf{u}^{(\mathrm{k})}>_{i j k}\right)\right]>_{i j k}^{m_{W}}\right. \\
& -\beta\left(\mathbf{g} \cdot \mathbf{e}_{\mathbf{z}}\right)<T^{n+1}-T_{o}>{ }_{i j k}^{m_{W}}+\left\langle\nabla \cdot \sigma_{\mathrm{z}}>{ }_{i j k}^{m_{W}}\right.
\end{aligned}
$$

where $k$ is the iteration index, and the gradient operator, $\nabla$, is expressed in rectangular cooróinates.

Recall from Section 2.2 that if the linearly implicit option is specified, the convection terms, $\left.<\nabla \cdot|\mathbf{u} q|^{(\mathrm{k})}\right\rangle_{i j k}^{m_{q}}$, are replaced by $\left\langle\nabla \cdot\left|\mathbf{u}^{\mathrm{n}} q^{(\mathrm{k})}\right|{ }_{i j k}^{m_{q}}(q=u, v\right.$, or $w)$, where $n$ is the time level.

\subsubsection{Energy Equation}

Equation (30) is the temporally differenced energy equation. The spatial differencing for this equation is given in Equation (62) below.

$$
\begin{aligned}
& \rho\left(\frac{e_{i j k}^{\mathrm{n}+1}-e_{i j k}^{\mathrm{n}}}{\Delta t}+<\nabla \cdot(\mathbf{u} e)^{\mathrm{n}}>_{i j k}+\frac{\xi<(e u)^{\mathrm{n}}>_{i j k}}{(i-1 / 2) \Delta x}\right)= \\
& \quad\left\langle\nabla \cdot(k \nabla T)^{\mathrm{n}}\right\rangle_{i j k}+\frac{\xi k}{(i-1 / 2) \Delta x}\left\langle\nabla \cdot\left(\mathbf{e}_{\mathbf{x}} T^{\mathrm{n}}\right)>_{i j k}+q_{i j k}\right.
\end{aligned}
$$

where the gradient operator, $\nabla$, is expressed in rectangular coordinates (Equation (11)). 


\subsection{Boundary Conditions}

Mesh cells containing fluid are surrounded by solid or fictitious boundary cells that impose the problem boundary conditions. Boundaries may be positioned along cell faces or they may pass diagonally through the centers of cell faces. The following sections describe how MAGMA sets velocities and temperatures in boundary cells in order to impose the physical boundary conditions.

\subsubsection{Velocity Boundary Conditions}

Boundary conditions associated with velocity are set in inactive cells adjacent to at least one active cell. Cell position and orientation determine how boundary velocities are set. There are two possible orientations with regard to setting velocity boundary conditions. The first orientation is when a wall or boundary lies along a cell face, and the second orientation is when a wall cuts diagonally through cell faces. These orientations are discussed separately in the sections that follow.

2.4.1.1 Walls Along Cell Faces. Consider Figure 5 as an example. Note that the positive $z$-direction is out of the paper. An analogous situation exists if $y$ and $v$ are replaced by $z$ and $w$, respectively, and the positive $y$ direction is into the paper.

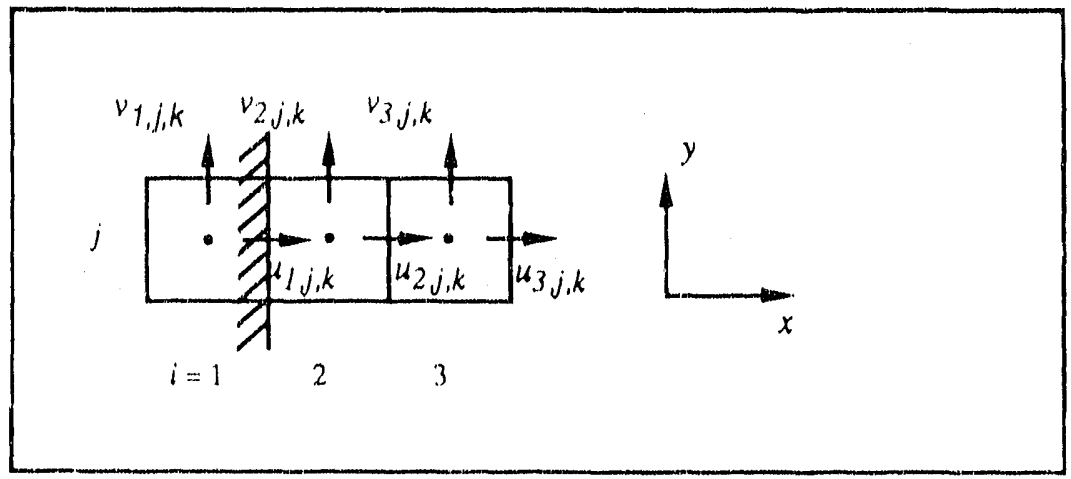

Figure 5. Wall boundary orientated along a cell face. 
Physically, there can be no flow across a wall. Therefore, the normal velocity component on a wall is identically set to zero regardless of the wall type (free slip, no slip, etc...) l.e.,

$u_{1 j, k}=0$

Physical characteristics of a free slip wall, a no-slip wall, or a wall with a known velocity determine how tangential velocity components are set in a velocity boundary cell. At a free silp wall, there is a zero shear stress, so the normal derivative of the tangential velocity must vanish. Thus, the tangential velocity component in the boundary cell is set equal to the tangentlal velocity component in the adjacent active cell. In Figure 5 this condition is satisfied by

$v_{l, j, k}=v_{2 j, k}$

No-slip boundary conditions require that tangential velocity components vanish at the wall. The tangential velocity in the boundary cell is set in order to satisfy this condition and in order to guarantee the finite difference approximation to the second normal derivative at the wall is consistent with a second order Taylor series approximation. For example, at cell $(2 j, k)$ in Figure 5 the code approximates the second derivative of $v$ in the $x$-direction as,

$\left(\frac{\partial^{2} \nu}{\partial x^{2}}\right)_{\text {ode }}=\frac{\left(v_{3, j, k}-2 v_{2 j, k}+v_{1, j, k}\right)}{\Delta x^{2}}$

The Taylor series approximation to this quantity is found by expanding $v_{3 j, k}$ and the velocity at the wall about the point $(2, j, k)$

$v_{3, i, k}=v_{2, j, k}+\Delta x \frac{\partial v}{\partial x}+\frac{\Delta x^{2}}{2} \frac{\partial^{2} v}{\partial x^{2}}+\cdots$
$v_{\text {wall }}=0=v_{2 j, k}-\frac{\Delta x}{2} \frac{\partial v}{\partial x}+\frac{\Delta x^{2}}{8} \frac{\partial^{2} v}{\partial x^{2}}+\cdots$

Neglecting higher order terms and solving for the second derivative gives

$\left(\frac{\partial^{2} v}{\partial x^{2}}\right)_{\text {I'aylor scrics }}=\frac{4}{3} \frac{\left(v_{3} j_{1}-3 v_{2} j_{k}\right)}{\Delta x^{2}}$ 
Equating Equations (65) and (68) and solving for $v / j, k$ gives,

$v_{1 j, k}=\frac{1}{3} v_{3 j, k}-2 v_{2 j, k}$

This expression satisfies the condition of zero tangential velocity at the wall as well as guarunting a consistent second order approximation to the second normal derivative. Analogous expressions arise for boundaries located on the other cell faces.

Spectfied velocity boundary conditions are easily imposed if the velocity components are located on the boundary. However, when this is not the case the boundary velocity component is once again set in a consistent, second order manner. For example, if the tangential velocity on the boundary in Figure 5 is $v_{L}$, the tangential velocity component in the boundary cell is calculated from,

$v_{1, j, k}=\frac{1}{3} v_{3 j, k}-2 v_{2, j, k}+\frac{8}{3} v_{L}$

Analogous expressions exist for other specified velocity boundary conditions of this type.

\subsubsection{Walls Cutting Dlagonally Through Cell Faces. No-slip walls passing} diagonally through cell faces allow the simulation of non-rectangular geometries. Diagonal boundaries can cut through two or three cell faces. Boundary cell velocities located on the wall are identically set to zero. Diagonal boundaries passing through only two cell faces require setting a langential velocity component not located on the wall. This situation is illustrated in Figure 6, in which the tangential velocity al point (1) (out of the paper) must be set in order to satisfy the noslip requirement on the boundiry. Note that the horizontal and vertical velocity components in cell $(i, j, k)$ are identically set to zero because they are directly located on the boundary. The third velocity component at point ( 1 ) coming out of the paper is set in the following manner:

1. The velocity in this direction is computed at point (2) by averaging the corresponding velocity components in cells $(i, j+l, k)$ and $(i+l, j, k)$. 


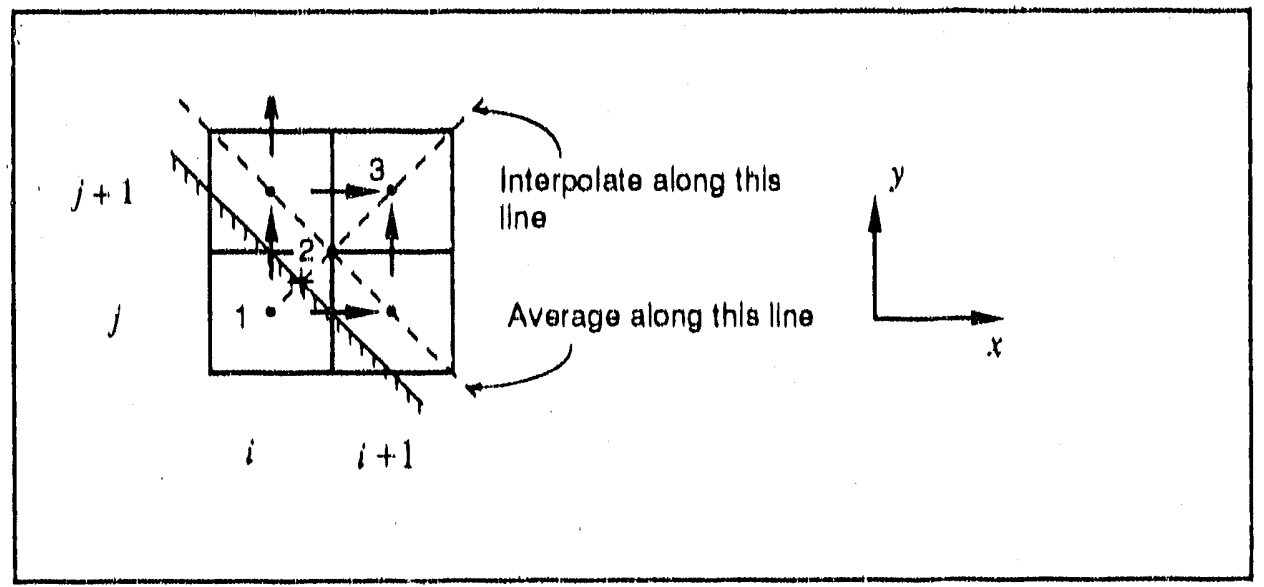

Figure 6. Diagonal wall boundary.

2. A second order polynomial is fitted through points (2) and (3), and the point indicated on the boundary in Figure 2.5.2. The velocity on the boundary is zero for this interpolation.

3. The velocity at point (1) is calculated from this second order polynomial equation.

'T..is procedure results in the following expression for the tangential velocity component, $w$, in cell $(i, j, k)$

$w_{i, j, k}=\frac{1}{3} w_{i+1, j+1, k}-w_{i+1, j, k}-w_{i, j+1, k}$

Analogous expressions arise when other diagonal boundary orientations are encountered.

\subsubsection{Temperature Boundary Conditions}

Temperature boundary conditions are imposed on the perimeter of the computational region. Four types of temperature boundary conditions are allowed: convective boundary conditions, constant heat flux, constant temperature, and adiabatic (zero heat flux) boundary conditions. 5 
For convective/mixed type boundary conditions, the boundary temperature is determined from an energy balance at the wall, where the heat transfer by convection equals the heat transfer by conduction at the wall. On the front boundary this condition is expressed as, ${ }^{5}$

$q^{\prime \prime}=h\left(T_{w}-T_{\infty}\right)=-k\left(\frac{d T}{d y}\right)_{w}=-k \frac{\left(T_{i j \max , k}-T_{i}\left(\max -1_{1} k_{2}\right)\right.}{\Delta x}$

where

$$
\begin{aligned}
& h=\text { convective heat transfer coefficient } \\
& k=\text { thermal conductivity } \\
& q^{\prime \prime}=\text { heat flux }
\end{aligned}
$$

subscripts:

$$
\begin{aligned}
& w \quad \text { wall value } \\
& \infty \quad=\quad \text { value of surroundings. }
\end{aligned}
$$

$T_{w}$ is approximated by

$T_{w}=\frac{1}{2}\left(T_{i, j \max , k}+T_{i, j m a x-1, k)}\right.$

and the value of the thermal conductivity on the wall is taken to be the value at the center of the cell adjacent to the wall. The convective-mixed type boundary condition on the front wall is then siatisfied by

$T_{i, j \max , k}=\frac{\frac{2 h \Delta y}{k_{i, j m a x-1, k}} T_{\infty}+\left(2-\frac{h \Delta y}{k_{i, j m a x-1, k}}\right) T_{i, j m a x-1, k}}{2+\frac{h \Delta y}{k_{i, j \max l, k}}}$

Expressions satisfying convective/mixed boundary conditions on the bottom, derriere, left, right, and top sides, respectively, are completely analogous to Equation (74). 
For a constant heat flux type boundury condition, the: boundary temperuture is once again determined from an energy balance at the wall. As an example, consider the caise where a constant heat flux, $q_{L}^{\prime \prime}$, exists across the left boundury of the computational region. ${ }^{5}$ The energy balance at the wall requires

$q_{L}^{\prime \prime}=-k\left(\frac{d T}{d x}\right)_{x=0}=-k_{2 j, k} \frac{\left(T_{2} j_{1} k-T_{1} j_{1} k\right)}{\Delta x}$

or

$T_{1, j, k}=T_{2, j, k}+\frac{q_{L}^{\prime \prime} \Delta x}{k_{2, j, k}}$

Analogous expressions can be derived for constant heat flux conditions along the bottom, derriere, front, right, and top walls, respectively. The adiabatic boundary condition is imposed by simply setting the heat flux across that wall to zero.

Constant temperature boundary conditions are easily imposed if the temperature is located on the boundary. However, when the boundary coincides with a cell face, the boundary temperature is set in a consistent second order manner similar to the method described for specified velocity boundary conditions. A constant temperature $\left(T_{B}\right)$ along the bottom wall requires the boundary cell temperature be calculated from the expression given in Equation (77). Expressions for the constant ternperature boundary conditions along the remaining walls are completely analogous to Equation (77).

$T_{i, j, 1}=\frac{1}{3} T_{i, 3,3}-2 T_{i j, 2}+\frac{8}{3} T_{B}$

\subsubsection{Boundary Conditions Summary}

Velocity boundary conditions are imposed after each iteration in the numerical solution to the momentum equation. Velocity boundaries are not restricted to the perimeter of the computational region. Velocity boundaries can lie along or pass diagonally through cell faces. Coxte logic identifies the type of boundary orientation and sets the boundary velocities accordingly. 
Types of allowable velocity boundary conditions include:

- No-slip

- Free slip

- Specified velocity.

Temperature boundary conditions are imposed after each time step on the perimeter of the computational region. Types of allowable temperature boundary conditions include:

- Constant temperature

- Constant heat flux

- Symmetric

- Convective/mixed. 


\section{CODE DESCRIPTION}

MAGMA is a FORTRAN computer code. Important aspects of the MAGMA code are discussed below including:

- Indirect addressing scheme

- General logic flow

- Subroutines and variables used by the code

- Code input and options

- Code output,

A variable dictionary is given in Appendix $C$, and a listing of a sample input data file is given in Appendix D.

\subsection{Indirect Addressing Scheme}

The indirect addressing scheme used by MAGMA is designed to avoid costly and unnecessary computation over inactive cells in the computational domain. By defining indirect addressing arrays the solution algorithm can sweep only over active cells in the mesh. This scheme is used in conjunction with the solution of the incompressible Navier-Stokes equations, but not the solution of the energy equation. Thus, heat flow is computed throughout the entire region, while fluid flow is computed only in molten cells.

IMAP is a four dimensional integer array. It is used to specify whether computational cells are active or inactive. And in the case of velocity boundary cells, the type of velocity boundary condition to be used. The first three indices of IMAP correspond to the indices of the computational grid. If the fourth index is 1 , the information stored in that array element determines whether cell $(i, j, k)$ is active or inactive. For example, if cell $(i, j, k)$ is an active cell then $\operatorname{IMAP}\left(I_{r} J, K, 1\right)=1$. Conversely, if cell $(i, j, k)$ is an inactive cell then $\operatorname{IMAP}(I, J, K, 1)=0$. If the fourth index is 2 , then the information stored in that array element determines the type of velocity boundary condition to be used in cell $(i, j, k)$. For example, if $\operatorname{IMAP}\left(I_{n} J, K, 2\right)=0$, then the no-slip boundary condition is enforced in cell $(i, j, k)$. Similarly, $\operatorname{IMAP}\left(I_{r} I, K, 2\right)=1$ indicates that the free 
slip boundary condition is applied in cell $(i, j, k)$, while $\operatorname{IMAP}(I, J, K, 2)=2$ indicates that the specified type velocity boundary condition is applied in cell $(i, j, k)$. The use of IMAP in the boundary condition logic requires: $I$ to range between 0 and $I M A X+1, J$ to range between 0 and $J M A X+1$, and $K$ to range between 0 and $K M A X+1$.

A two-dimensional integer array $(I D)$ is used to keep track of all the active cells in the region. The active cells are numbered consecutively using the IMAP array, sweeping through the mesh from left to right, front to derriere, and bottom to top, respectively. The $i, j$, and $k$ indices of each active cell are stored along with its cell number in order to keep track of cell position and relation to neighboring cells. The number of rows in this array is three, while the number of columns is the number of active cells (NCELLS). The column number is also the number of an active cell. Therefore, for each active cell (each column) the first row contains the $i$ coordinate index, the second row the $j$ coordinate index, and the third row the $k$ coordinate index.

A third integer array $(I D B C)$ is used to keep track of the velocity boundary cells and to set the velocity boundary conditions. The format of this array is the same as that described above. The column number corresponds to the number of the velocity boundary cell (NBC columns). The three rows contain the $i, j$, and $k$ coordinate indices corresponding to that velocity boundary cell.

\subsection{Overall Program Flow Chart}

The general logic flow of the MAGMA code is shown in Figure 7. Initially the code reads input data irom either an input file or a binary restart file. The restart file is used to restart a previous calculation from the point of the last binary data dump. Program variables and constants are initialized following input.

Following initialization, the code tests an input flag to determine if the energy equation is to be solved. If this energy flag tests true, the physical time step and iteration parameters are reset based on energy equation stability restrictions. Cell energies are updated to the new time level and cell temperatures are computed using the equation of state. Temperature boundary conditions are set and temperature dependent fluid properties such as thermal conductivity, viscosity, and specific heat capacity are specified. 

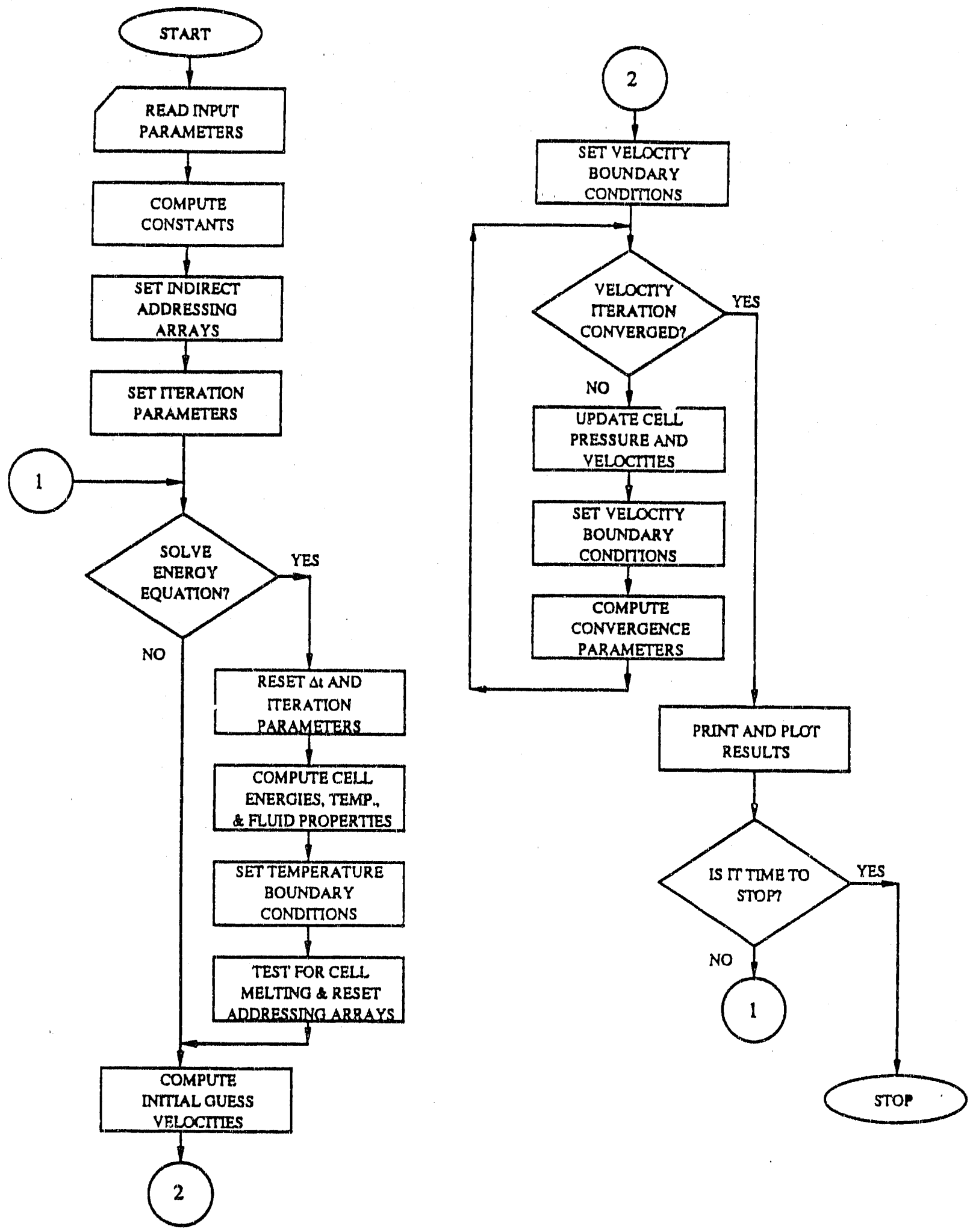

Figure 7. Top level flow chart for the MAGMA code. 
Next, the code computes initial guess velocities and proceeds to the iterative solution of the incompressible Navier-Stokes equations. Velocity boundary conditions are imposed following each iteration. The iteration continues until velocities and pressures have converged to the solution at the new time level. Data is written to data files and the code compares the new time level with the user specified ending time to determine whether to continue or terminate the run.

\subsection{Subroutine Organization and Description}

The following list defines the subroutines used in the MAGMA code. Primary functions of the subroutines are briefly described. Figure 8 presents a Hierarchical Table of Contents (HTOC), which demonstrates relationships existing between subroutines and the main code.

\section{ADDRSS (ADDReSS)}

This subroutine defines the indirect addressing arrays which relate the cell numbering scheme to the physical coordinates of the interior and boundary cells of the computational region. It is called by MAIN.

2. ADVNCE (ADVaNCE)

This subroutine updates all time dependent variables to the new time level once convergence has been obtained. It is called by MAIN.

\section{BNDRY (BounDaRY)}

This subroutine sets the velocity boundary conditions. It is called by MAIN.

\section{CONVRG (CONVERGe)}

This subroutine checks if the iteration scheme solution has satisfied the convergence criteria. It is called by MAIN.

\section{DUMP (DUMP)}

Performs a binary dump of program variables to a restart file. It is called by PRNT. 


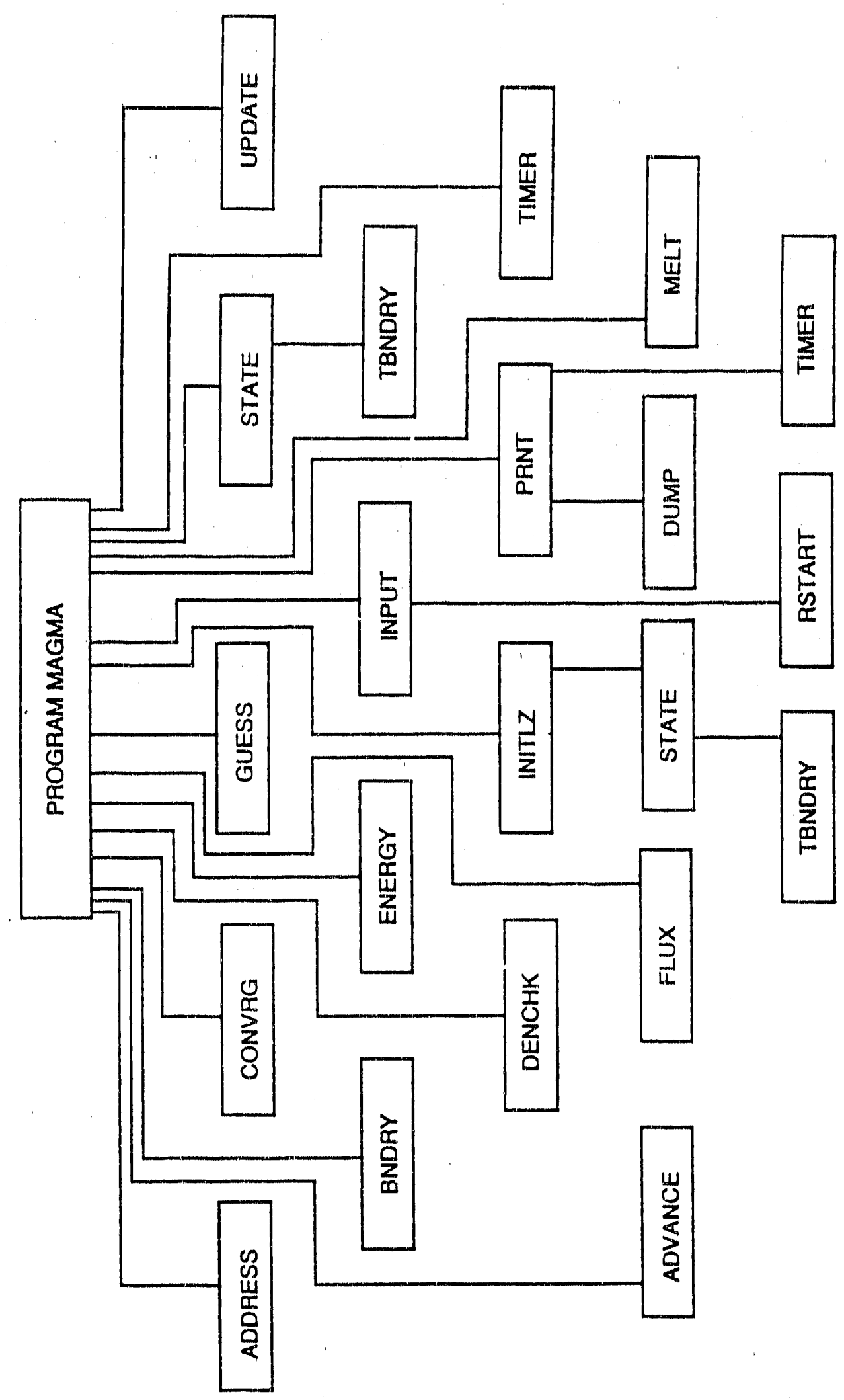

Figure 8. Subroutine hierarchical table of contents (HTOC). 


\section{ENERGY (ENERGY)}

This subroutine solves the energy equation. The governing partial differential equation is solved explicitly in time as described in the main text.

\section{FLUX (FLUX)}

This subroutine computes the velocity changes due to the convective and viscous terms in the momentum equation. It is called by MAIN.

\section{GUESS (GUESS)}

This subroutine computes the initial guess for the velocity field required for the iteration scheme. It is called by MAIN.

\section{INITLZ (INITiaLiZe)}

This subroutine initializes constant terms which are used throughout the rest of the program. It also calls STATE to set the initial energy field from the initial temperature and to compute the initial temperature dependent properties. It is called by MAIN.

\section{INPUT (INPUT)}

This subroutine reads in the necessary input data. It is called by MAIN.

\section{MELT (MELT)}

This subroutine tests cell energy values against the material latent heat of fusion value to determine if cell melting or freezing should occur.

\section{PRNT (PRiN'T)}

This subroutine outputs the results of the calculations. It is called by MAIN. 


\section{RSTART (Re START)}

Reads program variables from a binary restart file. It is called by INPUT.

14. STATE (STATE)

This subroutine uses an equation of state to relate the temperature to the energy or vice versa. It also calculates temperature dependent properties and calls TBNDRY to reset the temperature boundary conditions. It is called by MAIN and by INITLZZ.

15. TBNDRY ('Temperature BouNDaRY)

This subroutine sets the temperature boundary conditions. It is called by MAIN and by STATE.

16. TIMER (TIMER)

This subroutine keeps track of program times. It is called by MAIN and PRN'T.

\section{UPDATE (UPDATE)}

This subroutine updates the pressure and velocity fields to the new iterate level according to the fully/linearly implicit artificial compressibility iteration scheme with damping. It is called by MAIN.

\subsection{Code Options and Input}

A sample input file for the MAGMA code is located in Appendix D. Most of the variables in Appendix $D$ are self-explanatory. Those requiring additional information are described below. Note that additional variable definitions can be found in the variable dictionary in Appendix $\mathrm{C}$.

The first input variable (IRSTRT) determines if a previous calculation is to be restarted (IRSTRT $=1$ ) or if a new calculation is to be performed (IRSTRT $=0)$. If IRSTRT $=1$, the program reads all variables from a binary file called RINPUT. The remaining variables in the input file are read after the binary read from RINPUT. This allows additional program control and flexibility, 
however the user must be certain that input variables are consistent with the variables of the previous calculation. If $I R S T R T=0$, the program starts a new calculation.

ALPHA is a weighting parameter used in the differencing of the convective terms of the Navier-Stokes equations. It represents the percentage of upwinded or donor cell differencing. $A L P H A=1$ represents pure donor cell differencing, while $A L P H A=0$ ) represents pure centered differencing.

$C Y L$ is the two-dimensional cylindrical coordinate system flag. $C Y L=1$ indicates that two-dimensional cylindrical coordinates are to be used. Setting $C Y L$ to one also requires that $D E L Z$ be set to a negative number. A negative $D E L Z$ is interpreted by the code logic as an input signal for a purely two-dimensional calculation. The $y$-axis becomes the axis of symmetry for two-dimensional calculations and the $x$-coordinate becomes the radial coordinate. $C Y L=0$ indicates that either a two or three dimensional simulation is to be performed using rectangular coordinates. Three dimensional calculations are performed if $D E L Z$ is greater than zero, and twodimensional calculations are performed if $D E L Z$ is less than zero. Note that the $x-y$ plane is the default for two-dimensional calculations.

$E C O E F 1, E C O E F 2, E C O E F 2$, and $E C O E F 3$ are temperature coefficients in the quadratic equation of state (Equation (14)) where $E C O E F 1=a 1, E C O E F 2=a 2, E C O E F 3=a .3$, and ECOEF4 $=a 4$.

EPSI is the tolerance value for the velocity divergence condition given by Equation (28), i.e., $E P S I=\varepsilon_{1}$. TOL is the tolerance value for the convergence condition given by Equation (29), i.e., $T O L=\varepsilon_{2}$.

$T Q B, T Q D, T Q F, T Q L, T Q R, T Q T$ are temperature boundary condition parameters associated with the bottom, derriere, front, left, right, and top boundaries, respectively. The interpretation of these parameters depends upon the temperature boundary condition flags ITMPB, ITMPD, ITMPF, ITMPL, ITMPR, and ITMPT'. The letters B, D, F, L, R, and T refer to the bottom, derriere, front, left, right, and top boundaries of the computational region. Table 1 indicates the interpretation of TQn as a a function of ITMPn, where $n$ represents $B, D, F, L, R$, or $T$. As indicated in Table 1, TQH is the convective heat transfer coefficient when the convective wall boundary condition $(I T M P n=3)$ is selected. 
Table 4. Interpretation of temperature boundary condition parameters

LTMPn

1

2

3
Interoretution of $70 n$

Wall temperalure

(constant temperature boundary condition)

Wall heat tlux

(constant heat flux boundary condition)

Tempernture of surroundings

TQH is the heat transfer coefficient

(convective boundary condition)

TWFIN and IFREQ are program control variables. TWFIN sets the ending time for the calculations and IFREQ deternines the frequency of data outputs. Data is written to a restart file and several output data files (i.e., mlidat, outdat, prsdat, tmpdat, and veldat, and pliddat) every IFREQ time cycles.

IEIVERGY, IFIMP, IGUESS, IMELT, and IVISC are program option flags. IENERGY $=1$ indicates that the energy equation is to be solved, whereas IENERGY $=0$ turns off the energy solution subroutine. IMELT controls the code melting and freezing options. IMELT $=1$ allows cell melting and freezing, while $I M E L T=0$ turns off this option. IVISC controls the variable viscosity option in the MAGMA code. $I V I S C=1$ indicates that the variable viscosity formulation is to be used, while IVISC $=0$ indicates that the constant viscosity formulation is to be used. Tables 2 and 3 indicate the yarious options associated with the IFIMP and IGUESS flags.

Additional input options may be directly hard wired into the Magma code. For example, expressions relating the fluid properties to temperature must be directly hard wired into the STA'TE subroutine. Initial non-uniform temperature or velocity distributionti may be coded directly into the INPUT subroutine. The initial distribution of active cells in the computational region may also be coded directly into the INPUT subroutine. This task is accomplished by simply setting the necessary elements of the IMAP array to 1. Special boundary conditions not included in the MAGMA code can also be hard wired into the code. The BNDRY subroutine contains velocity 
Table 2. Interpretation of the IFIMP variable flag

IFIMP
0
$\begin{aligned} & \text { Indicates the fully implicit solution algorithm is to bo used in conjunction } \\ & \text { with the momentum equation. }\end{aligned}$
$\begin{aligned} & \text { Indicates the linearly implicit solution algorithm is to be used in conjunction } \\ & \text { with the momentum equation }\end{aligned}$
Indicates the semi-implicit solution algorithm is to be used in conjuncilon
with the momentum equation

Table 3. Interpretation of the ICUESS variable fling

IGUESS
Interpretalion
$\begin{aligned} & \text { Initial velocity guess is to be computed from an explicit approximation to the } \\ & \text { momentum equation. }\end{aligned}$
Initial velocity guess is the velocity solution from the previous time step,
Initial velocity guess is to be computed from an extrapolation from the two
previous time step velocity solution.


boundary condition logie und the TBNDRY subroutine contalns the temperature boundary condition loglo. MAGMA allows no-slip and freo slip wall velocity boundary conditions; and constant temperature, constant heat flux, and convective temperature boundary conditions.

Array dimensions and common blocks can be changed in a single INCLUDE file named 'comd, $h$ ', which is included in the mainline and all subroutines. All importunt PARAMElYER statements, DIMENSION statements, and COMMON blocks, are also loculed in this tile.

\subsection{Code Output}

Data is output to four ASCI data files and one binary data file after every IFREQ thme cycles. The binury data file is a resturt file named ROUT'PT'. This file contuins a binary dump of ull variables necessary for a successful resturt of a previous calculation. In order to restart a calculation, the flag IRSTR'T is set to one and ROUTPT' is renumed RINPUT before the program is executed.

The four ASCI data files ure output in a simllar fastion. After IFREQ time cycles the velocity, temperature, pressure are written to the files named: 'veldat', 'tmpdat', and 'prsdat', respectively. Other variable arrays such as energy and temperature dependent properties are written to the file named 'outdat'. If cell melting is allowed, the molt front profile is written to the file named 'mltdat'. The form of a program output is similar for each of these files. At each output, header information is written to the data file before uny data. This header information includes a brief description of the type of data (i.e, VEL_OCITY DATA), the output time, the number of cycles, the mesh spacing, etc... In the veldat data file, following the header information the $x, y$, and $z$ coordinutes are written with the corresponding $u, v$, and $w$ velocity components on the same output card (i.e., $x, y, z, u, v, w$ ). Other data files write the $x, y$, and $z$ coordinates with the corresponding variable value on the same output card (i.e., $x, y, z, p)$.

After IFREQ time cycles, the time, the cycle count, and the itcration count are written to the standard output device so that the user can monitor the progress of the code calculations. Note that this output should be tailored to meet the user's own monitoring requirements. If the code is executed in batch mode, this output should be redirected to a data file or suppressed.

A post-processing routine may be necessary to convert MAGMA data into the correct form for use with an external plotting package. The MAGMA cole does not have any internal plouing capability. 


\section{CODE TESTING AND VERIFICATION}

MAGMA has been assessed against numerous numerical and analytical test problems found In the literature. Table 4 presents a summary of these test problems. They have been divided into five main categories: 1) T'wo-dimensional advection, 2) Two-dimensional conduction, 3) T'wodimensional natural convection, 4) Three-dimensional natural convection, and 5) Melting,

During two dimensional tests, each of the three two-dimensional planes were tested (i.e., $x-y, x-z$, and $y-z$ ). The results obtained were identical, verifying that symmetry existed in each of the three coordinate directions. Although tests were performed on each of the two dimensional planes, two dimensional calculations are presently restricted to the $x \cdot y$ plane.

Quantitutive datu comparisons were possible in assessing MAGMA against tests $1,2 a, 2 b$, 3b, and 3c. MAGMA results compared well with analytical solutions for tests $1,2 a$, and $2 b, 6,7,8,9$ Good agreement was obtuined with numerical solutions for tests $3 b$ and $3 c .{ }^{12}$ Qualitative comparisons were made with numerical solutions to tests $3 a, 4 a, 4 b$, and 5. MAGMA results also compared favorably with these numerical solutions, especially considering differences in the numerical techni(ques and computational meshes. $10,13,14$

The results from MACiMA simulations of tests $3 b$, $4 a$, and 5 are presented below in order to demonstrate the capabilities and versatility of the code. These simulations were chosen because they involve two and three dimensional natural convection, rectangular and cylindrical coordinates, and heall transfer and fluid flow during melting.

T'est 3b is a benchmark numerical solution for steady state, two-dimensional, natural convection. 12 The problem geonetry and thermal boundary condition are illustrated in Figure 9. All boundaries are rigid, no-slip walls. The left wall is maintained at the hot temperature, $T_{h}$. The right wall is maintained at the cold temperature, $T_{6 .}$. Both the front and derriere boundaries are adiabatic walls.

MAGMA calculated the steady state solution by marching the transient solution out to a steady state, while Reference 12 used a steady state solution algorithm to avoid computing the Iransient solution. In addition, full donor cell differencing of the convective terms limited the the MAGMA solution to first order accuracy, while the numerical solution of Reference 12 was second order accurate. 
Table 4. Summary of MAGMA test problems

Tesl Calegery

1. Adrection (2-D)
1. Numl:

Coord. Systom:

Crid:

Boundaries:

Initial Conditlons:

Paramctors:

Compurison:
Driven Cavily

2-D Rec langular 4()$\times 40$

Left - No-sllp

Right - Nomslip

Front - Spectifiat

Derriere $\quad-\mathrm{N}()-s i l p$

Zero inlurnal volocily

$\mathrm{Rc}=4(0)$

Qualitative \& quantitallve will numerical results

2. Conduction (2-D)

2a. Name

Coord. System:

Crid:

Boundaries:

Initial Conditions:

Parametors:

Comparison:

Transient Conduction-Rectangular

2-D Reclangular

2()X4) (rect. plate)

Zero surface teinp.

$T(x, y, 1=())=x y$

$k=c:=r=1$

Quantuative with analylical solution

2b. Namc:

Coord. System:

Grid:

Boundarics:

Inltial Conditions:

Parameters:

Comparison:

Transiont Conduction-Cylindrical

2-D Cylindrical

10X10) (finite cylinder)

Zero surfuce temp.

$T(x, y, t=0))=1$

Thermal diffusivily $=(0.1$

Qualitative with analytical solution

8

9

Henled Fluid Layer

3a. Name:

Coord. System:

Grid:

Boundrics:

Initial Conditions:

2-D Rectangular 40X20) (rect. plate, g $=-g_{\mathrm{g}} \mathbf{y}$ )

No Slip walls

Front -Isothermal

Derricere $\quad-$ Isothermal $\left(I_{D}>T_{F}\right) \quad 10,11$

L.cft, Right -Adiabatic

Zero, velocity

Uniform 'Temp, gradient

Initial sinusoidal tcmp, perturbation

Paramoters:

$\mathrm{Ra}=3(),(0), \mathrm{Pr}=1,0$

Comparison:
Quallative with stcady state numerical solution 
Table 4. (continued)

Test Cillegory

f'est Number and Desceriviou

Belcorencs

3b. Name:

Coord. Systom:

Grid:

Boundarles:

Benclumark Natural Convection

2-D Rectangular

$10 \times 10,20 \times 20,40 \times 40)(b=-g(y)$

No-slip walls

Left --Isothormal

Right - -Isothermal $\left(I_{L}>T_{R}\right)$

Fronl

-Adiabatic

Derriere $\quad$ Adlabatic

Initial Conditions: Uniform temportuture

Paramclors: $\quad R a=10,(0) 0, P r=0.71$

Comparison: $\quad$ Quallative \& quantitative with

steady sute numerical solution

3c. Namo:

Benchmark Natural Convection

Coord.

2-D Rectangular

Grid:

10X10, 20X20, 40X40) (g= -g ey $)$

Boundarics:

No-slip walls

Left -..Isothermal

Right -.Isothermal $\left(I_{L}>I_{R}\right)$

Front -Adlabatic

Derricre -Adiabatic

Initial Conditions: Unilorm temperature

Parancters:

$R a=10(),(0), P r=0.71$

Comparison:

Qualitalive \& quantitative with

stcally state mumerical solution

4. Natural

Convection (3-D)

4a. Name:

3-D Natural Convection

Coord. System:

3-D Rectangular

Gricl:

$9 \times 9 \times 9(g=-g(y)$

Boundarics:

No-slip walls

Lelt --1 sothermal, $l ' L=l^{\prime}$

Right $\quad$-Isothormal, $T_{R}=?$

Front $\quad-$ - Isothermal, $T_{F}=l^{\prime}$

Top $\quad$-Isothermal, $T \cdot T=T^{\prime}$

Bottom - Isothermal, $I_{B}=$ ?

Derriere $\quad$-Isothermal- $I_{D}>l$

Initial Conditions:

Uniform lemperature

Parameters:

$R a=1(0,())(), P r=0.72$

Comparison:

Qualitative with stcady state

numerical solution 
Table 4. (continued)

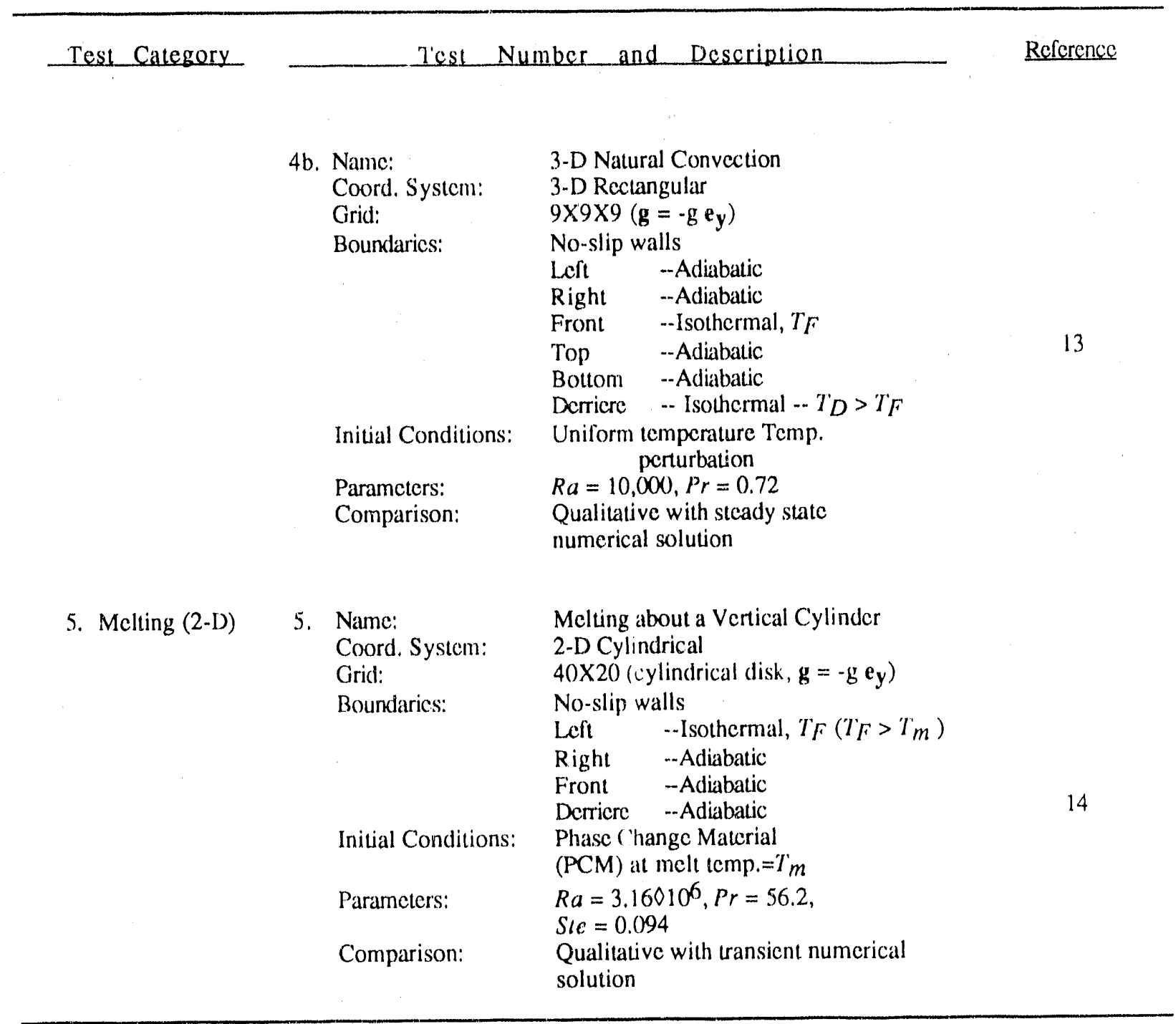




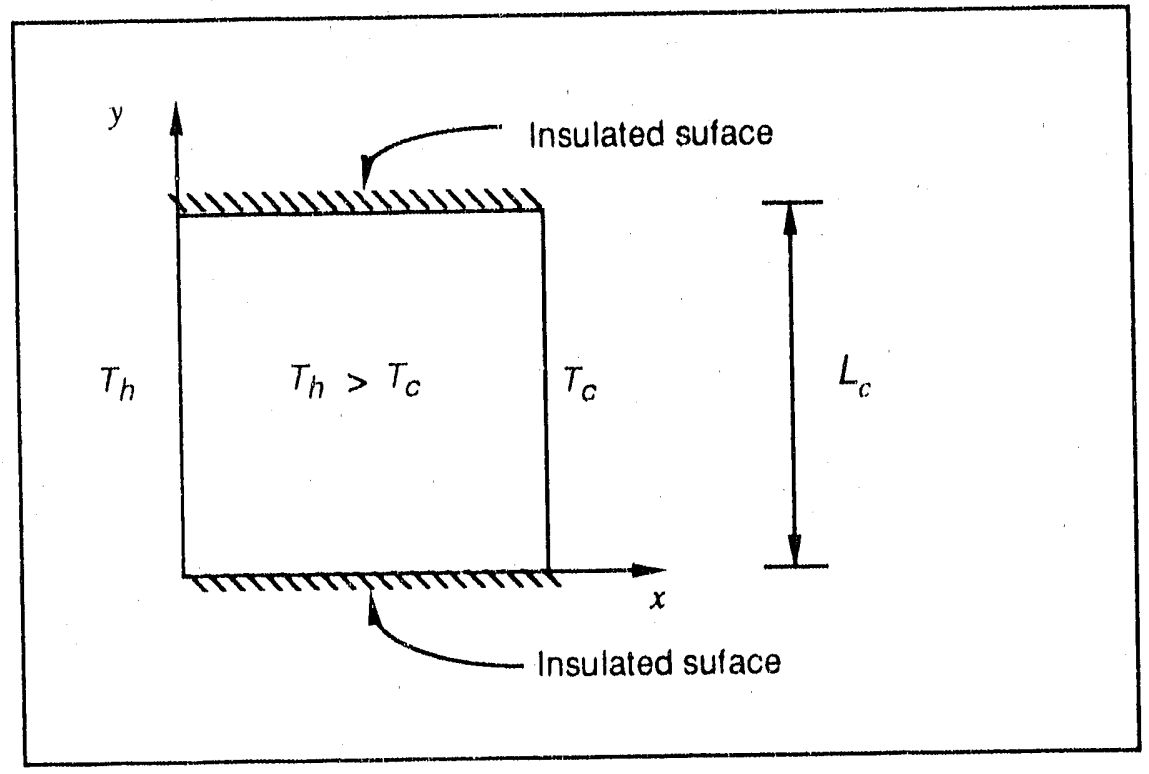

Figure 9. Geometry and thermal boundary conditions for test $3 \mathrm{~b}$.

Quantitative comparisons of data values from Reference 12 and the MAGMA solution are shown in Table 5. The Reference 12 benchmark solution in tic !ast column was calculated by extrapolating the solutions from the two finest meshes $(\Delta x=\Delta y=0.05$ and $\Delta x=\Delta y=0.025)$ to approximate the exact solution $(\Delta x=\Delta y=0)$. Reference 12 miximum velocity values were obtained from interpolation, while the MAGMA values represent the maximum cell centered mesh values. Note that velocities have been scaled by $\frac{\alpha}{L_{C}}$ and lengths by $L_{C}$, where $\alpha$ is the thermal diffusivity. Generally good agreement was obtained, considering the differences in the numerical techniques. Table $\because$ indicates that the MAGMA solution is converging to the benchmark solution as the grid size is reduced.

Figures 10 and 11 present the steady state velocity vectors and temperature isotherms, respectively, for MAGMA calculations on a $40 \mathrm{X} 40(\Delta x=\Delta y=0.02 .5)$ mesh. Comparison of Figure 11 against the steady state temperature isotherms from Reference 12 (Figure 12) demonstrates good agreement. 
Table 5. Data comparison with test number number $3 \mathrm{~b}$

\begin{tabular}{|c|c|c|c|c|c|c|c|}
\hline \multirow[b]{2}{*}{ Data Value } & \multicolumn{2}{|c|}{$\Delta x \equiv \Delta y=0.1$} & \multicolumn{2}{|c|}{$\Delta x=\Delta y=0.05$} & \multicolumn{2}{|c|}{$\Delta x=\Delta y=0.025$} & \multirow{2}{*}{$\begin{array}{l}\begin{array}{r}\Delta x \rightarrow 0 \\
\Delta \nu \rightarrow 0\end{array} \\
\end{array}$} \\
\hline & MAGMA & Reference 13 & MAGMA & Reforence 13 & MAGMA & Reference 13 & \\
\hline $\begin{array}{l}u_{\max } \\
y\end{array}$ & $\begin{array}{c}15.047 \\
0.85\end{array}$ & $\begin{array}{r}16.243 \\
0.808\end{array}$ & $\begin{array}{r}15.723 \\
0.825\end{array}$ & $\begin{array}{r}16.189 \\
0.820\end{array}$ & $\begin{array}{c}15.955 \\
0.8125\end{array}$ & $\begin{array}{r}16.182 \\
0.823\end{array}$ & $\begin{array}{r}16.178 \\
0.823\end{array}$ \\
\hline $\begin{array}{l}v_{\max } \\
x\end{array}$ & $\begin{array}{c}16.733 \\
0.15\end{array}$ & $\begin{array}{r}18.055 \\
0.139\end{array}$ & $\begin{array}{r}18.757 \\
0.125\end{array}$ & $\begin{array}{r}19.197 \\
0.125\end{array}$ & $\begin{array}{c}19.263 \\
0.1125\end{array}$ & $\begin{array}{r}19.509 \\
0.120\end{array}$ & $\begin{array}{r}19.617 \\
0.119\end{array}$ \\
\hline$N \bar{u}$ & 2.190 & 2.171 & 2.206 & 2.212 & 2.230 & 2.234 & 2.243 \\
\hline $\begin{array}{l}N u \\
\left(x=\frac{1}{2}\right)\end{array}$ & 2.042 & 2.170 & 2.164 & 2.213 & 2.218 & 2.235 & 2.243 \\
\hline $\begin{array}{l}N u \\
(x=0)\end{array}$ & 2.383 & 2.307 & 2.271 & 2.255 & 2.254 & 2.242 & 2.238 \\
\hline
\end{tabular}




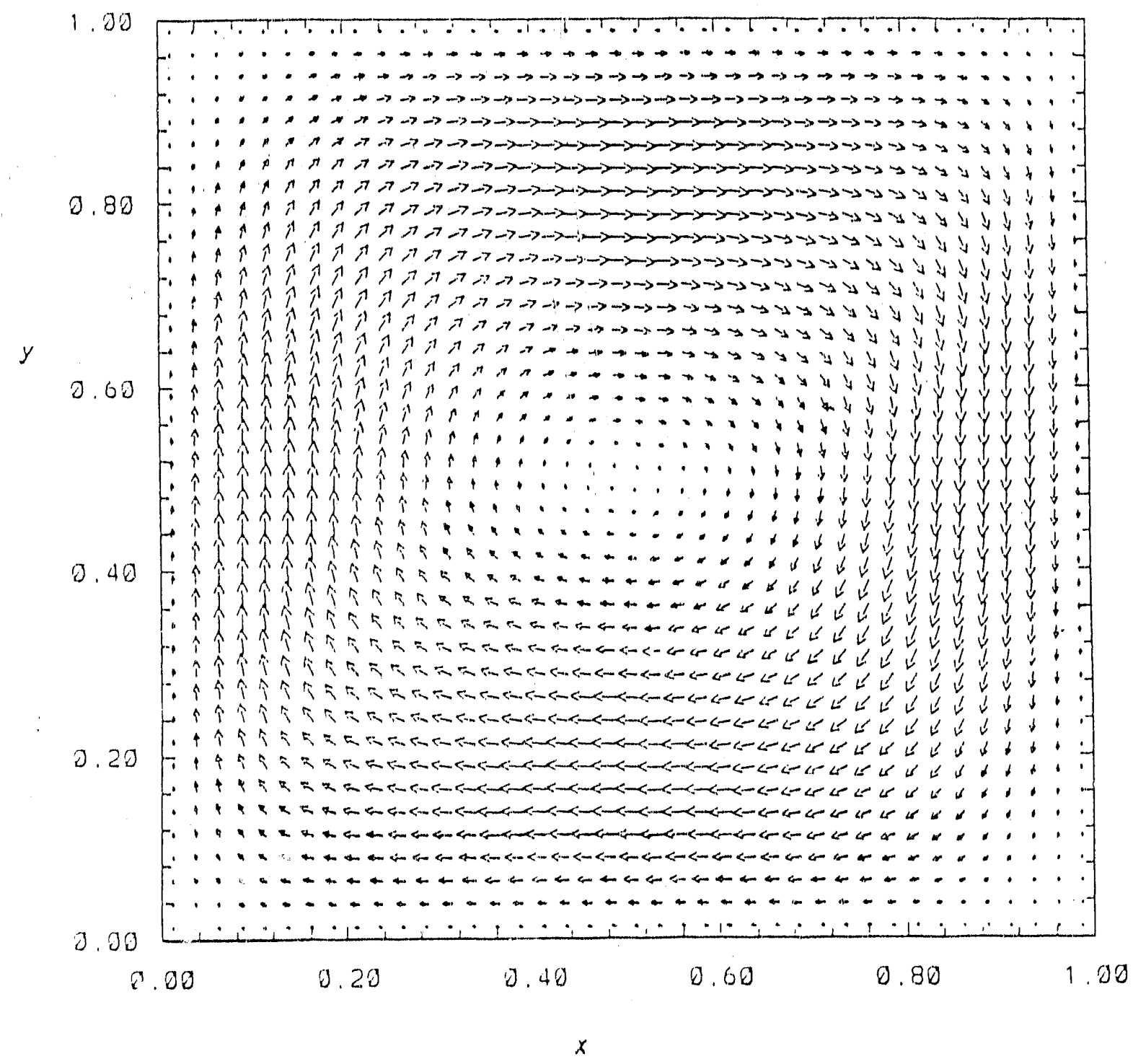

Figure 10. MAGMA steidy state velocity vectors for test 36 (maximum dimensionless velocily vector $=19.25$ ). 


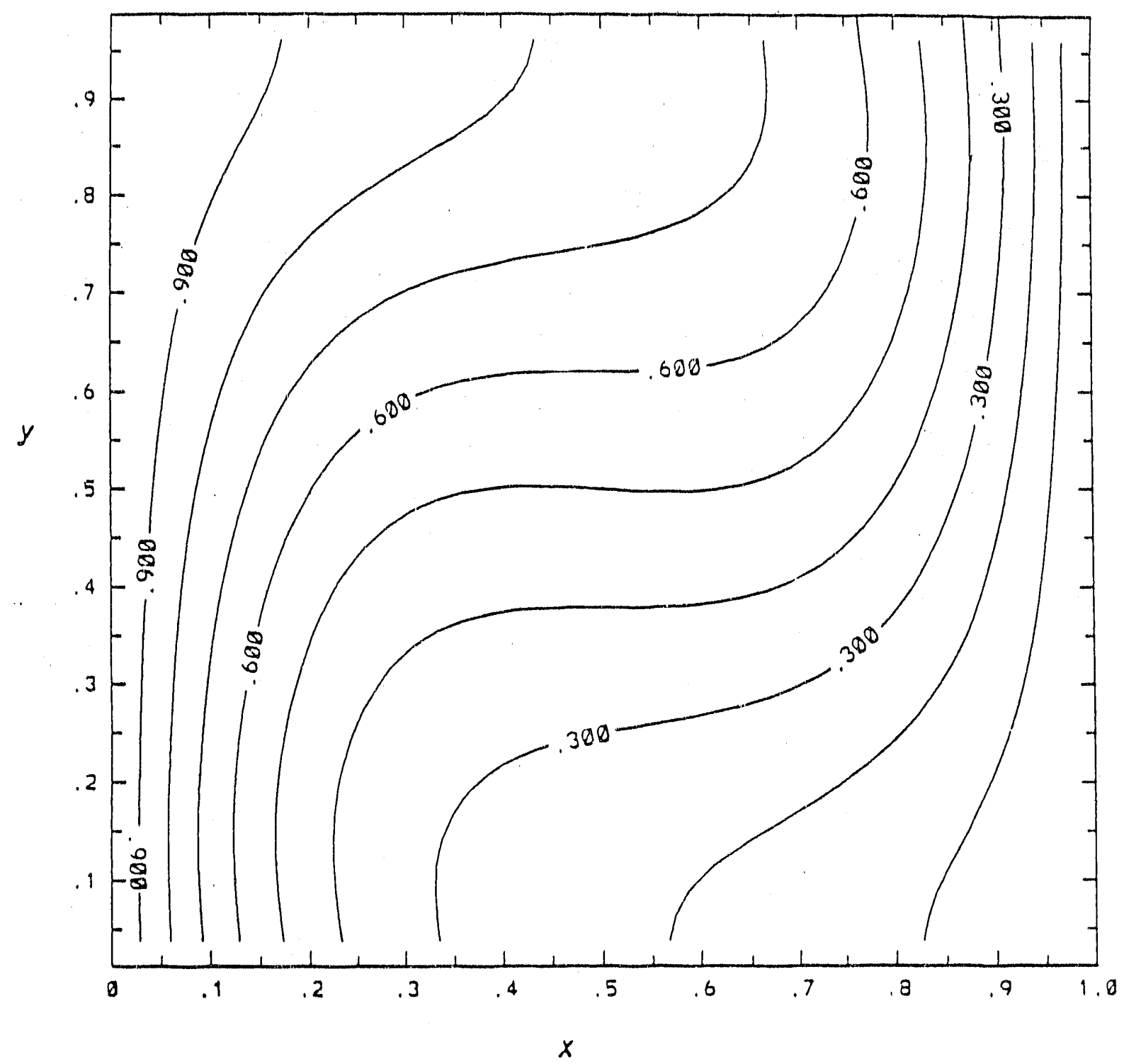

Figure 11. MAGMA steady state temperature isotherms for test $3 b$ (contours at () $(0.10) 1)$. 


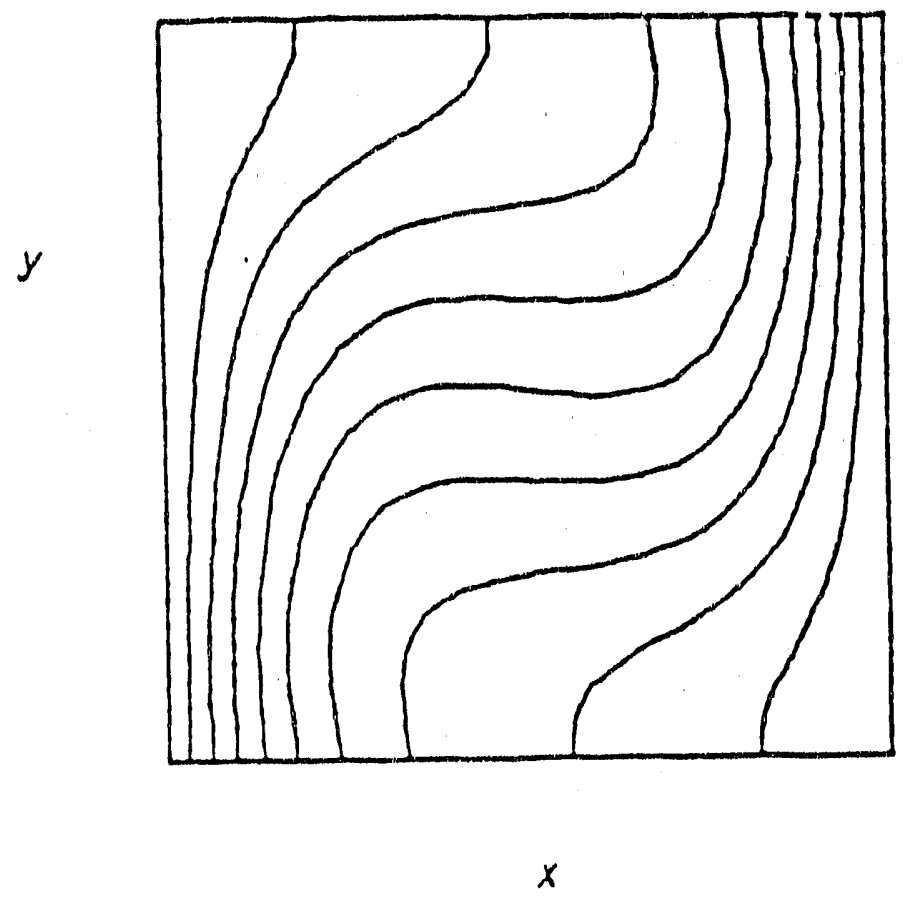

Figure 12. Reference 12 steady state kemperature isotherms for lest 3b (contours ill () (0.1()) 1). 
Test $4 \mathrm{a}$ is a three dimensional natural convection simulation. The geometry and thermal boundary conditions for this test are illustrated in Figure 13.13 All boundaries are rigid, no-slip, isothermal, walls. The temperatures on the left, right, bottom, top and front walls are equal to the cold temperature, $T_{G}$. The derriere wall is set to the hot temperature, $T_{h}$. The initial temperature is set to the average of $T_{C}$ and $T_{h}$. These and other parameter specifications are listed in Table 4.

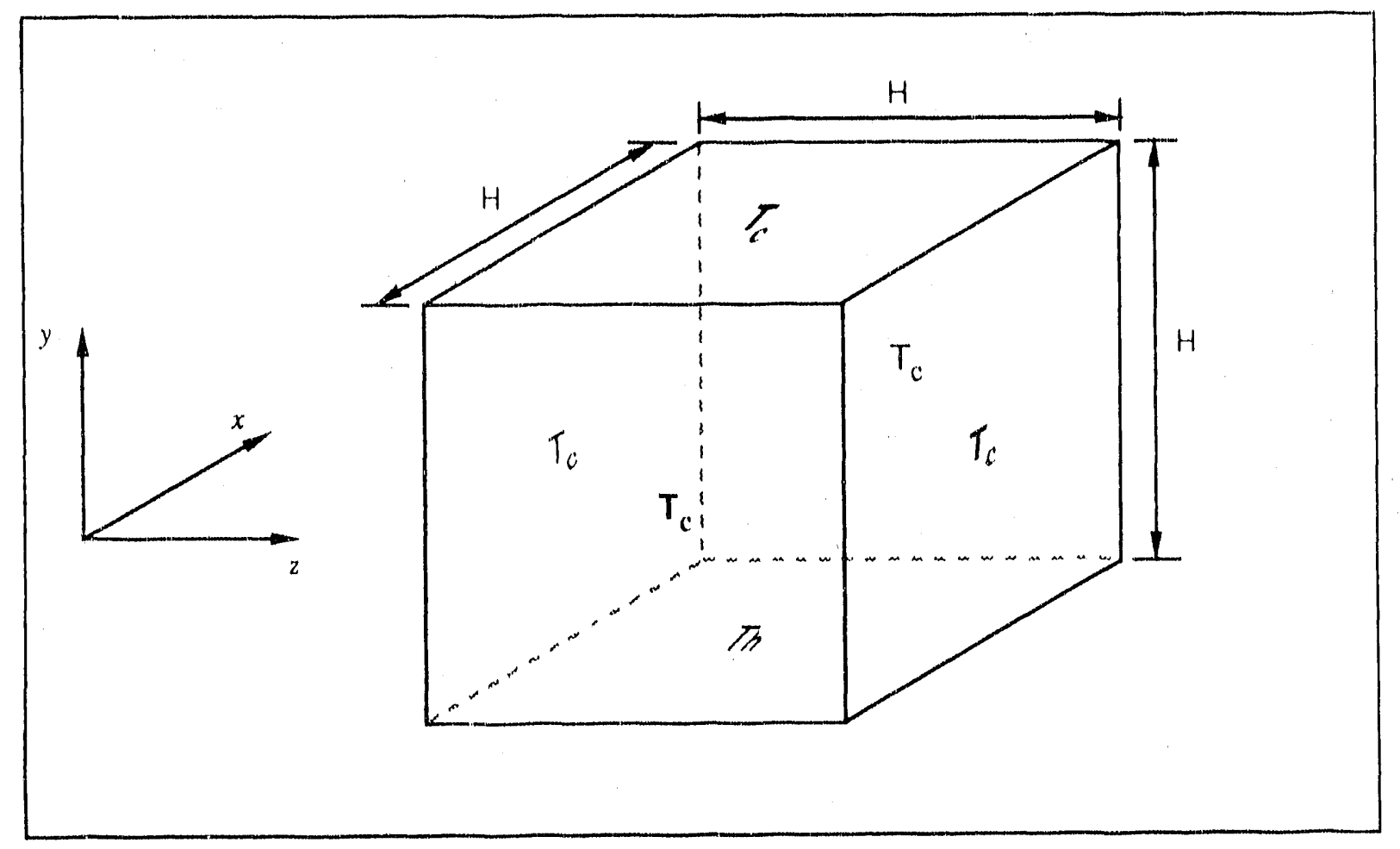

Figure 13. Geometry and thermal boundary conditions for test $4 a$.

Cooling on the side walls immediately initiates a downward flow of liquid. This liquid is heated as it passes along the derriere wall causing it to rise up through the center of the cube. The steady state natural circulation pattern is thus characterized by liquid falling along the side walls and subsequently rising through the center of the cube. MAGMA-calculated temperature and vertical velocity $(v)$ profiles at mid-height $(y / H=0.5)$ for each of the $x-y$ planes are shown in Figures 14 and 15, respectively. Calculated results from Reference 13 are shown in Figures 16 and 17 for comparison purposes. Qualitatively the plots are similar, but quantitative agreement is marginal. 


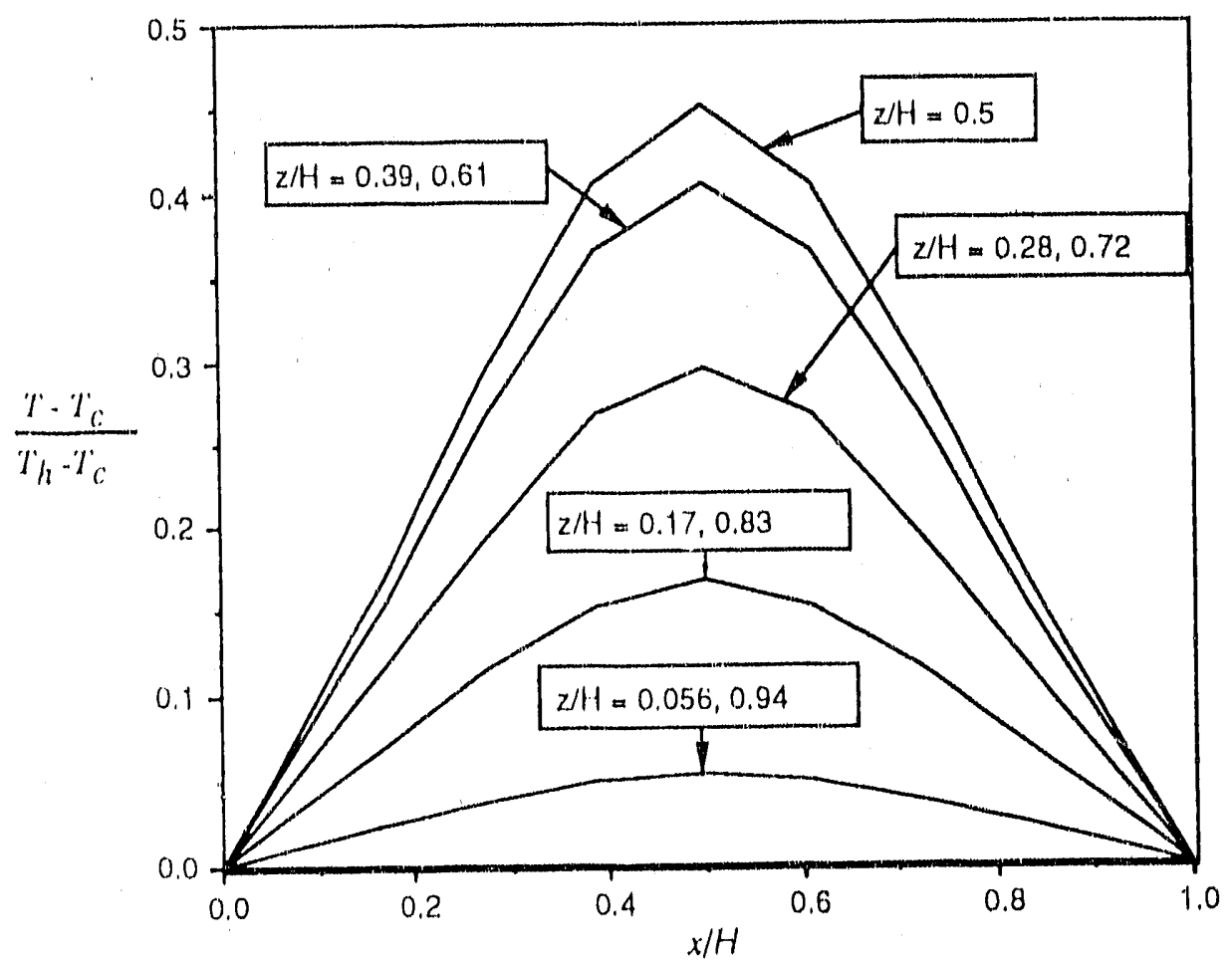

Figure 14. MAGMA iemperature profiles at mid-height for test 4a. 


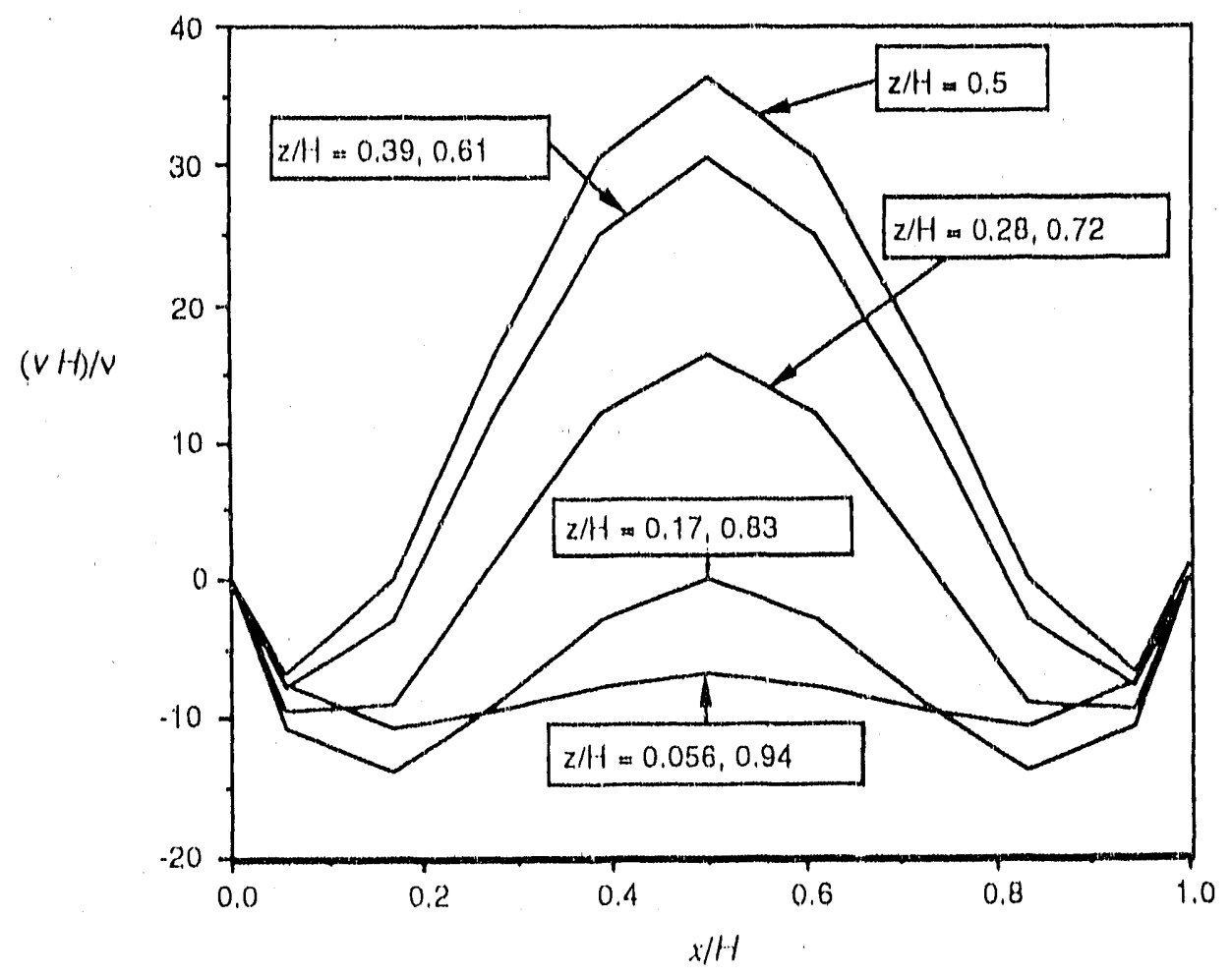

Figure 15. MAGMA vertical velocity profiles at mid-height for test ta. 


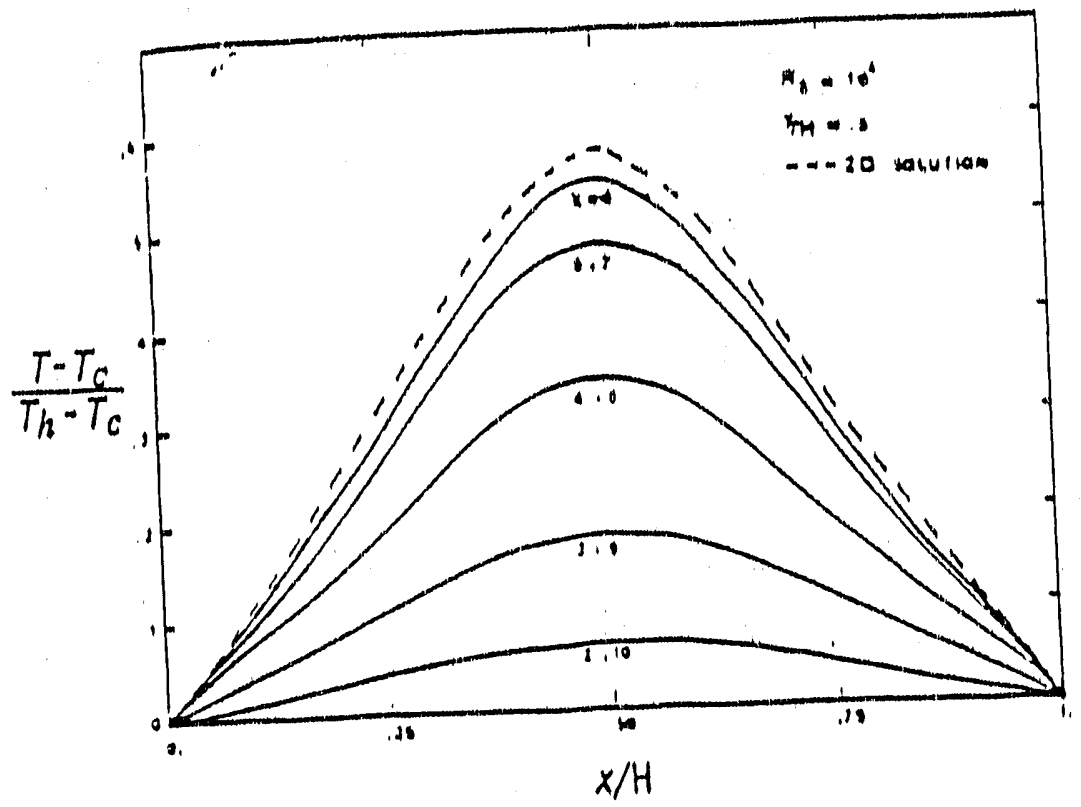

Figure 16. Reference 13 stendy state temperature profiles at mid-height for test $4 a$.

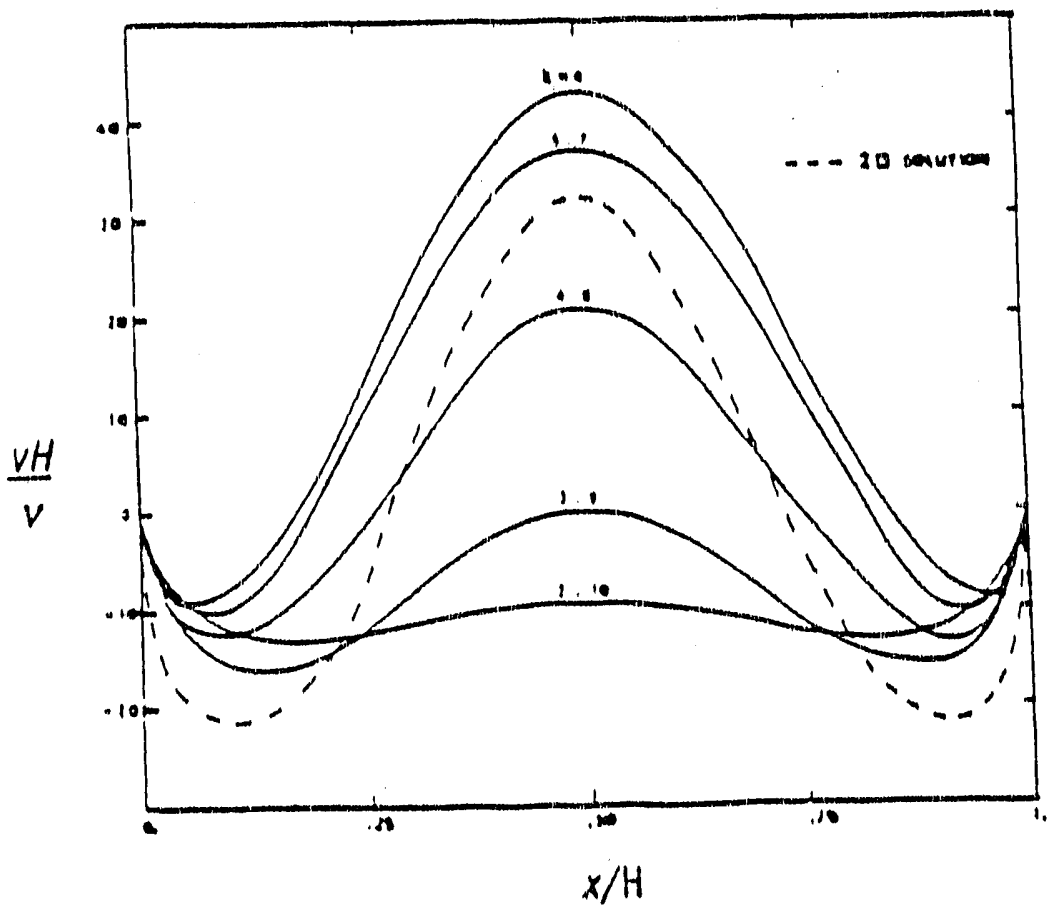

Figure 17. Reference 13 steady state vertical velocity profiles at mid-height for test $4 a$. 
An explanation for the quantitative differences between the two numerical results has not yet been determined. MAGMA-caloulated steady state temperature contours and velocity vectors for the plane $z / H=0.5$ are shown in Figures 18 and 19 , respectively. Corresponding plots from Reference 13 are shown in Figures 20 and 21 . "The two numerical solutions qualitatively predict similar steady state behavior.

Test 5 investigates natural convection during melting about a healted finite cylinder. ${ }^{14}$ The geometry and thermal boundary conditions for this test are lllustrated in Figure 22. All boundaries are rigid, and have no-slip walls. The left wall coincides with the surfice of the cylinder and is maintained at the temperature $T_{o}$, which is higher than the melt temperature, $T_{m}$, of the Phase Change Material (PCM). All other boundaries are insulated, adiabatic walls. The transient results of this simulation are identified by a dimensionless time defined by Reference 14 as

$\tau=\frac{\alpha \operatorname{tc}\left(T_{O}-T_{m}\right)}{H^{2} L}$

where $\alpha$ is the thermal diffusivity, $t$ is the physical time, $c$ is the specilic heat capacity, $L$ is the latent heat of fusion, and $H$ is the height of the cylinder.

The initial temperature of the PCM was set to the PCM melt temperature, $T_{m}$. MAGMA ussumed all cells were initially in the solid phase (no melting). Heat is transferred from the left wall (i.e., the cylinder) to the PCM, due to the initial temperature difference. Initially, this energy transfer is used to supply the latent heat necessary to initiate cell melting in the layer of cells immediately adjacent to the cylinder. The entire first layer of cells melt when $\tau=0,00147$. Cell melting is followed by cell temperature increases, which in turn initiates heat transfer to the second layer of cells. Natural convection begins when the first two layers of cells have completely melted. The buoyancy driven natural convection flow transfers more heat to the cells near the front boundary, causing these cells to melt before the other cells in the layer. MAGMA calculated melt front profiles resulting from this melting process are shown in Figure 23. Qualitatively, the MAGMA melt front profiles agree reasonably well with the results from Reference 14, presented in Figure 24. Note that both numerical solutions predict the melt front extending farther across the front boundary. MAGMA velocity vector and temperature contour plots at $\tau=0.0983$ (Figures 2.5 and 26 , respectively) demonstrate the heat transfer and fluid flow behavior in the melt region. 


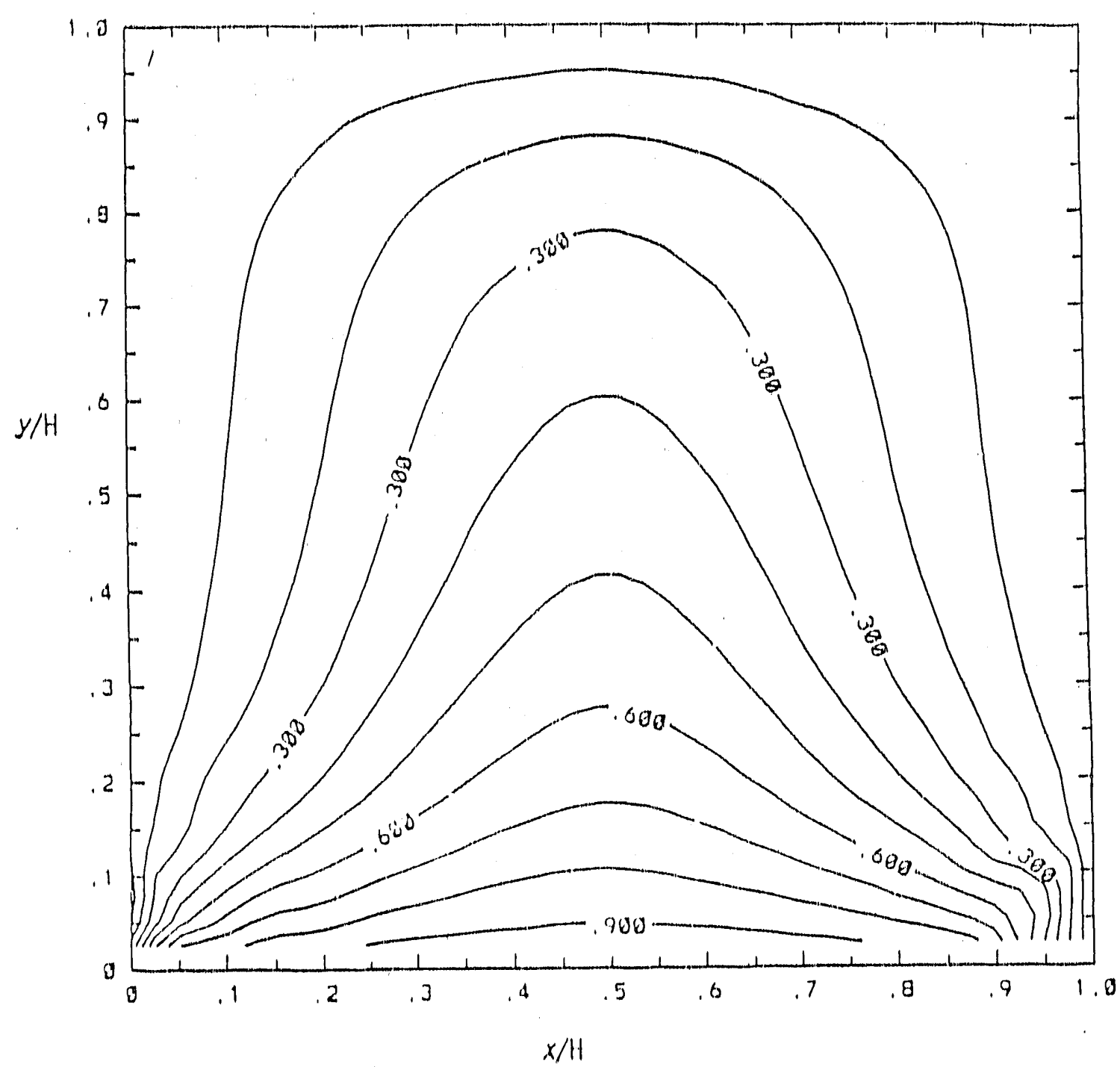

Figure 18. MAGMA stealdy state temperature contours at $z / \mathrm{H}=0.5$ for test $4 a$ (contours all () (0,10) 1). 


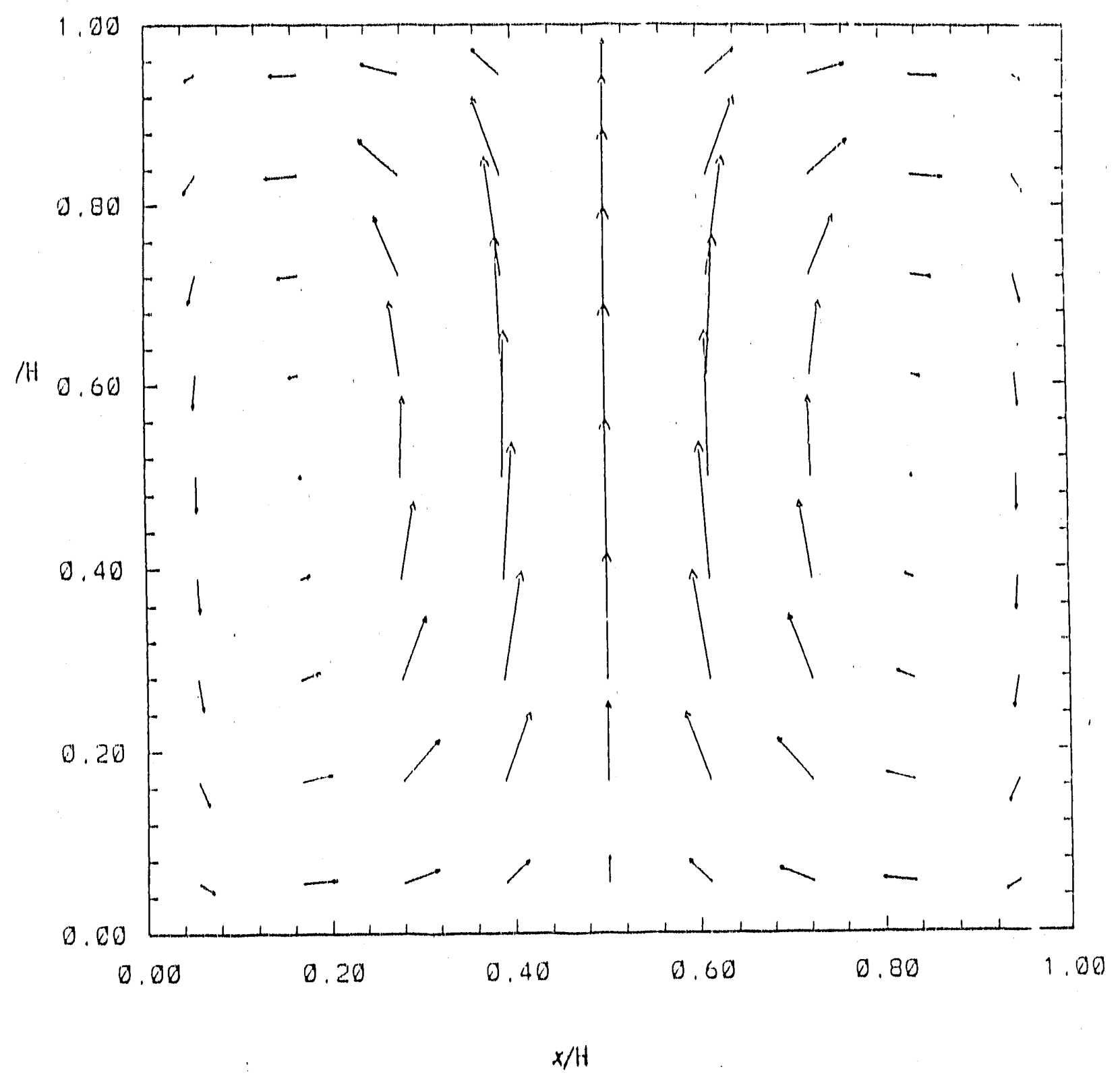

Figure 19. MAGMA steady state velocity vectors at $z / H=0.5$ for test $4 a$ (maximum dimensionless velocity $=36.34$ ). 


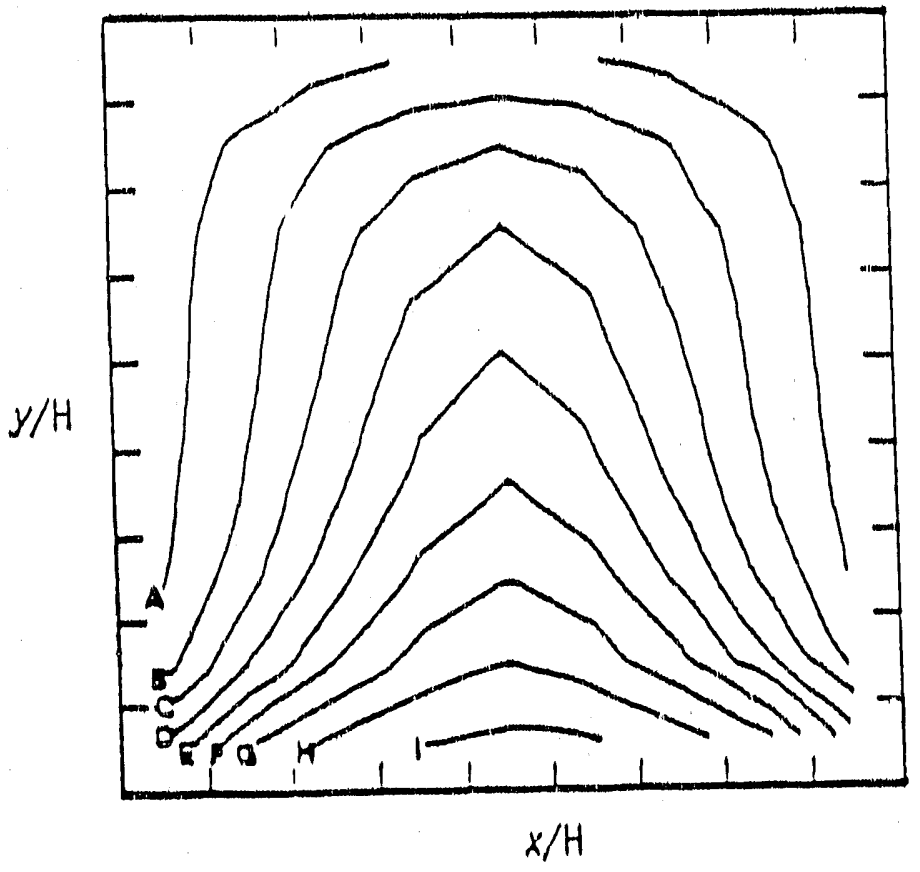

Figure 20. Reference 1.3 steady stille lemperature contours at $z / 4=0.5$ for test $4 a$ (comlours at $0(0.1()) 1$ ).

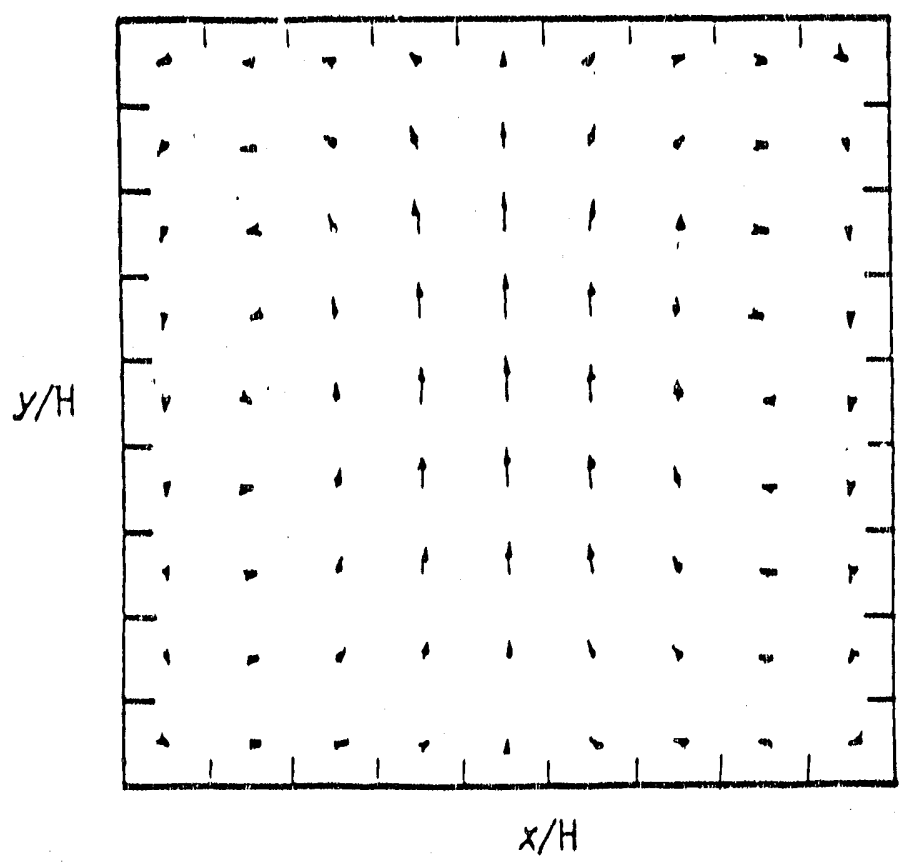

Figure 21. Reference 13 steidly state velocity vectors at $z / 1 \mathrm{I}=0.5$ for lest $4 a$ (maximum dimensionless velocily $=$ b43). 


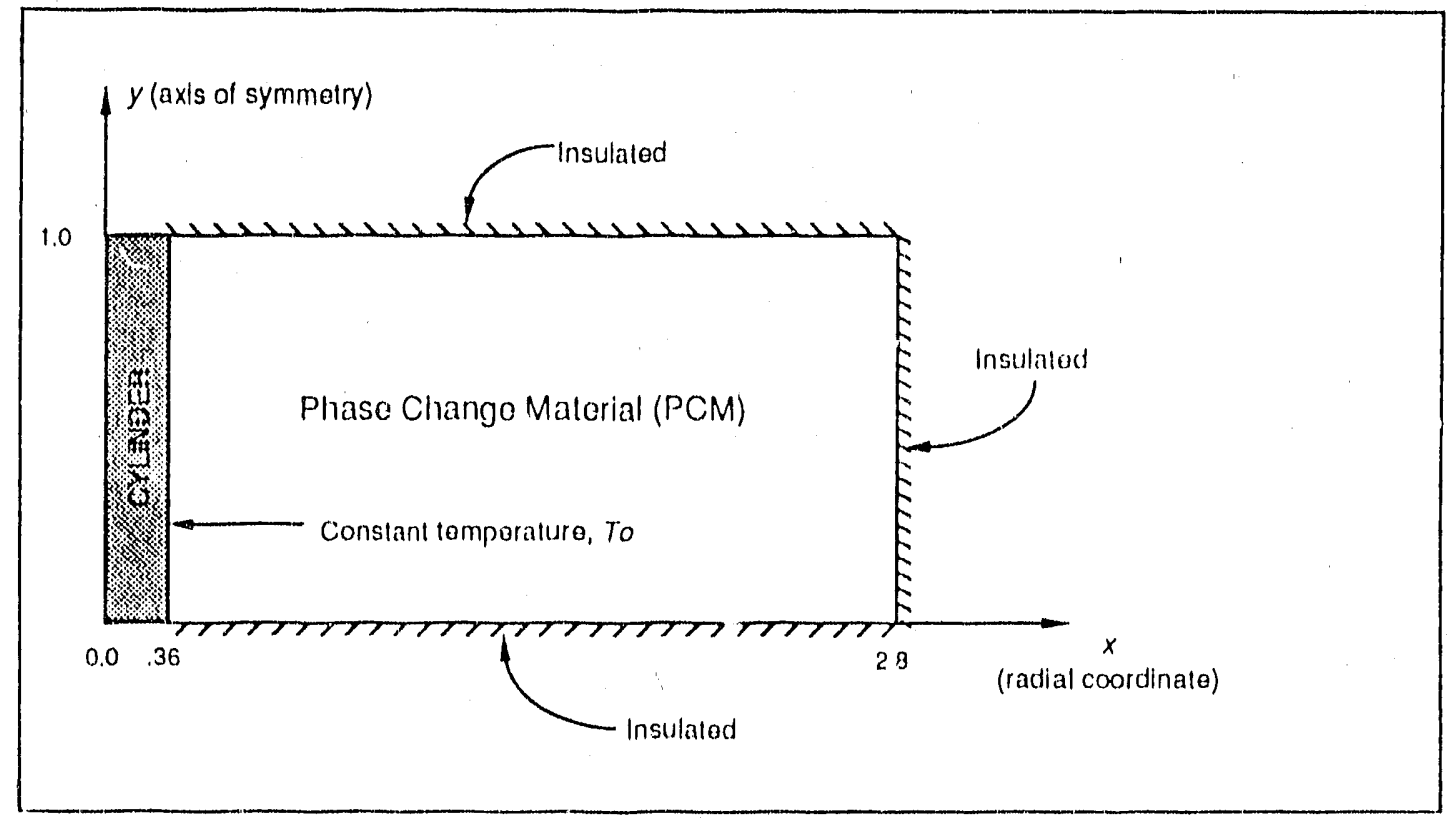

Figure 22. Gcometry and thermal boundary conditions for test 5 . 


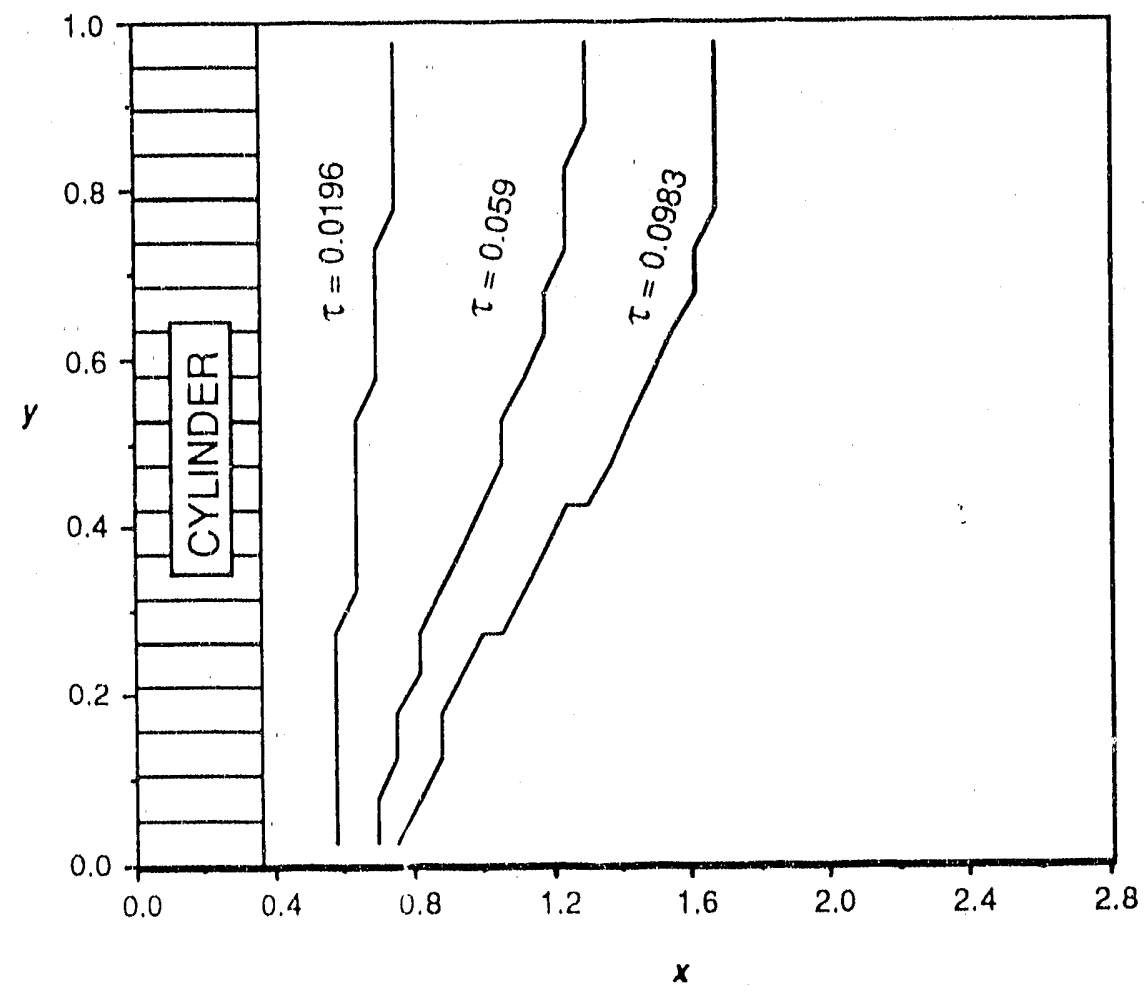

Figure 23. MAGMA melt front profiles versus nondimensional time. 


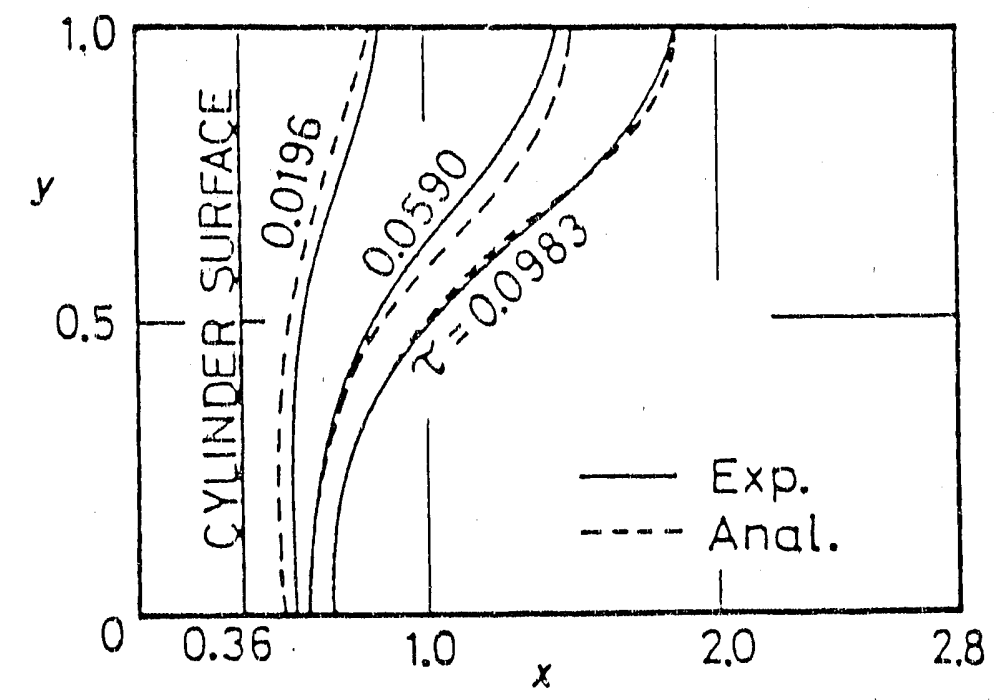

Flgure 24. Reference 14 melt front profiles versus nondimesional time. 


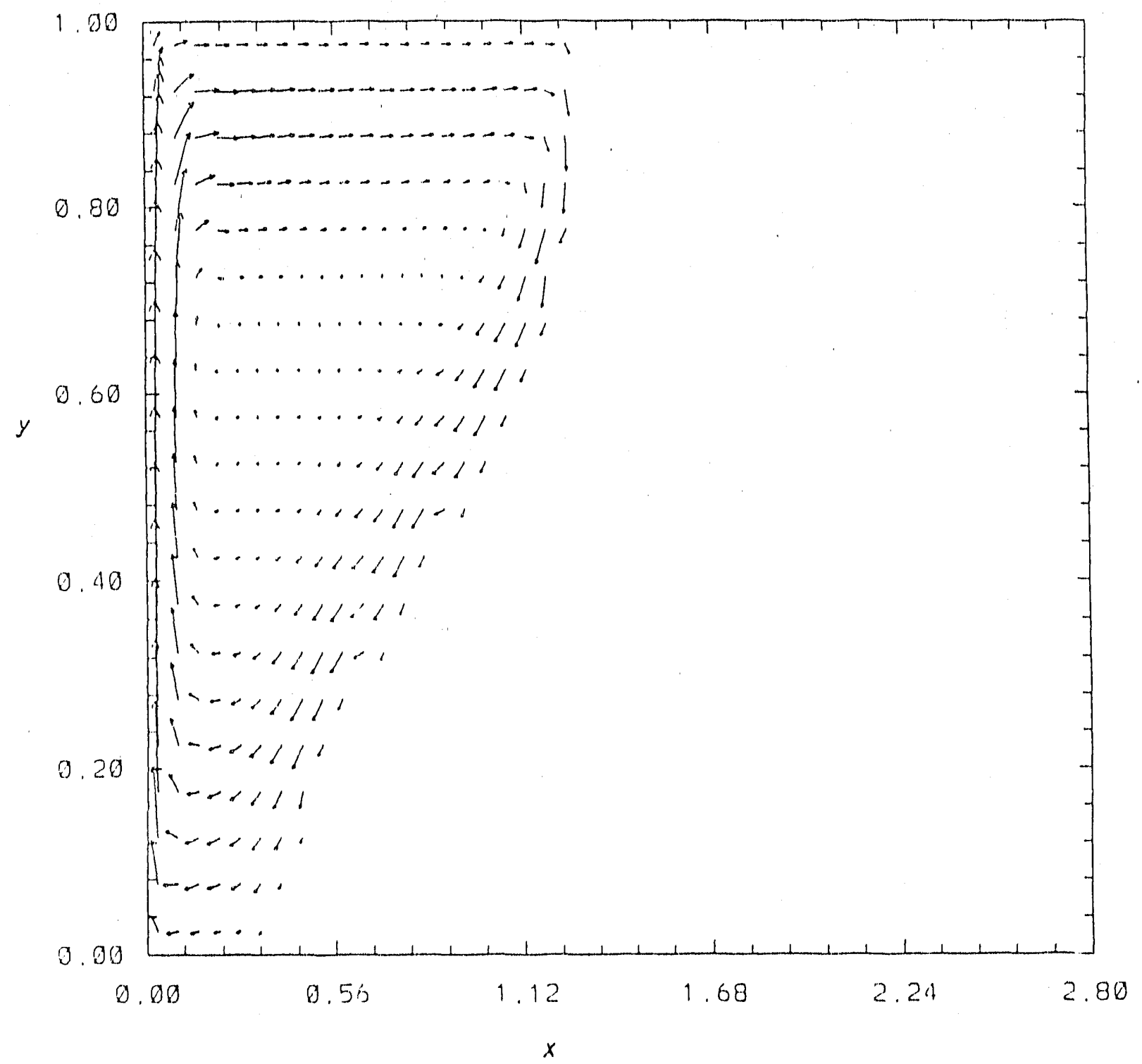

Figure 25. MAGMA velucity vectors at $\tau=0.0983$ for test 5 . 


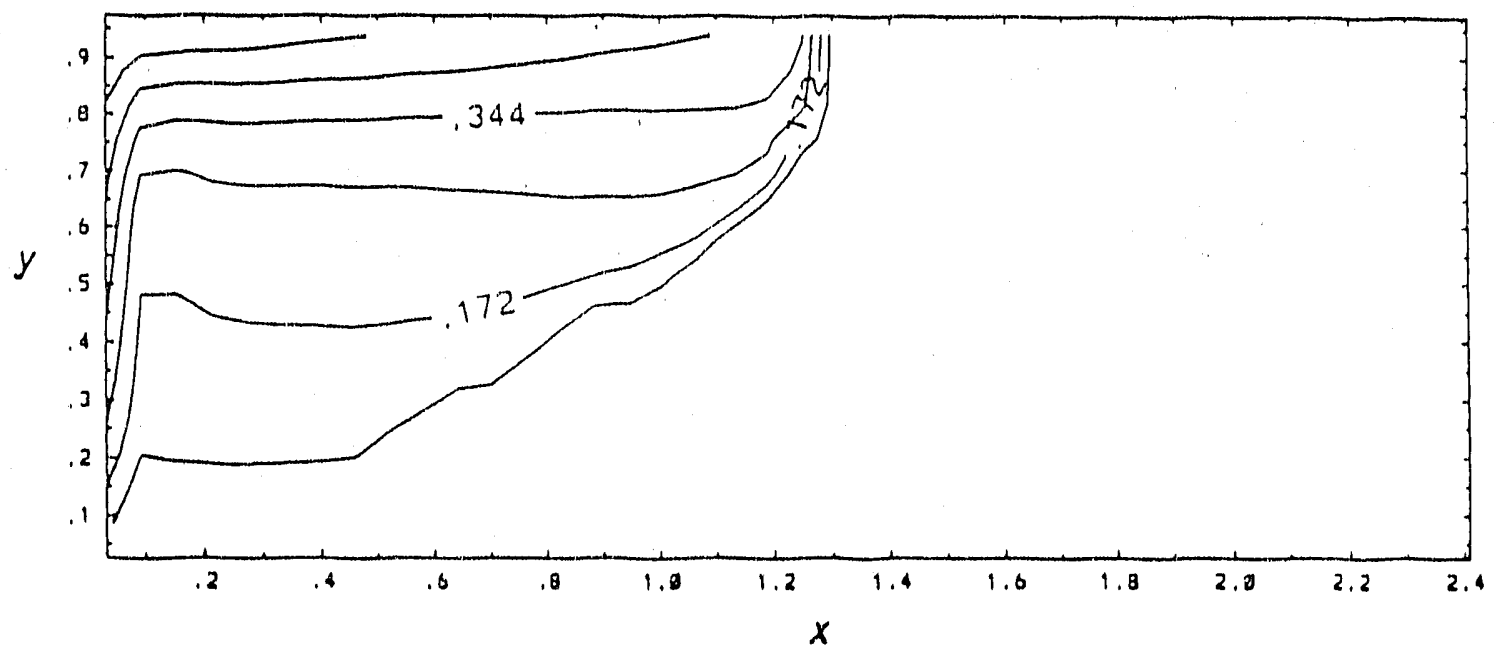

Figure 26. MAGMA temperatture contours at $\tau=0.0983$ for test 5 (contours at () $(0.10) 1)$. 
Table 6 compares the calculated dimensionless molten volume of the melt region obtained from MAGMA and from Reference 14. The dimensionless molten volume is defined by Reference 14 as

$\mathrm{Vol}=\frac{H^{2}}{x_{0}^{2}} \int_{0}^{1} \frac{x_{m}^{2}}{H^{2}} d y-1$

where $H$ is the height of the cylinder, $x_{o}^{2}$ is the radial coordinate of the cylinder surface, and $x_{m}^{2}$ is the radial coordinate of the melt front. Generally good agreement is obtained.

Figure 27 presents the transient response of the average Nusselt number. The large oscillations in this figure result from the nature of the MAGMA melting model. When a cell or group of cells melt, the average Nusselt number is significantly affected by the subsequent rise in cell temperatures. This effect is especially apparent during the early stages of the transient, when entire layers of cells melt simultaneously. Oscillations were not encountered in the Reference 14 simulation because the melt front was allowed to expand continuously. Figure 28 shows the results of the average Nusselt number calculated from Reference 14. However, MAGMA and Reference 14 calculations predicted similar transient behavior of the average Nusselt number.

Table 6. Comparison of the transient dimensionless molten volume for test number 5

Dimensionless Time

0.0196

0.059

0.0983
MAGMA

2.06

6.89

11.09
Reference 14

10.0

It is anticipated that improved accuracy and agreement with Reference 14 could have been obtained through mesh refinement. Reference 14 used a variable transformation from the physical coordinates to the computational coordinates to obtain a mesh with considerably higher resolution than the MAGMA mesh. 


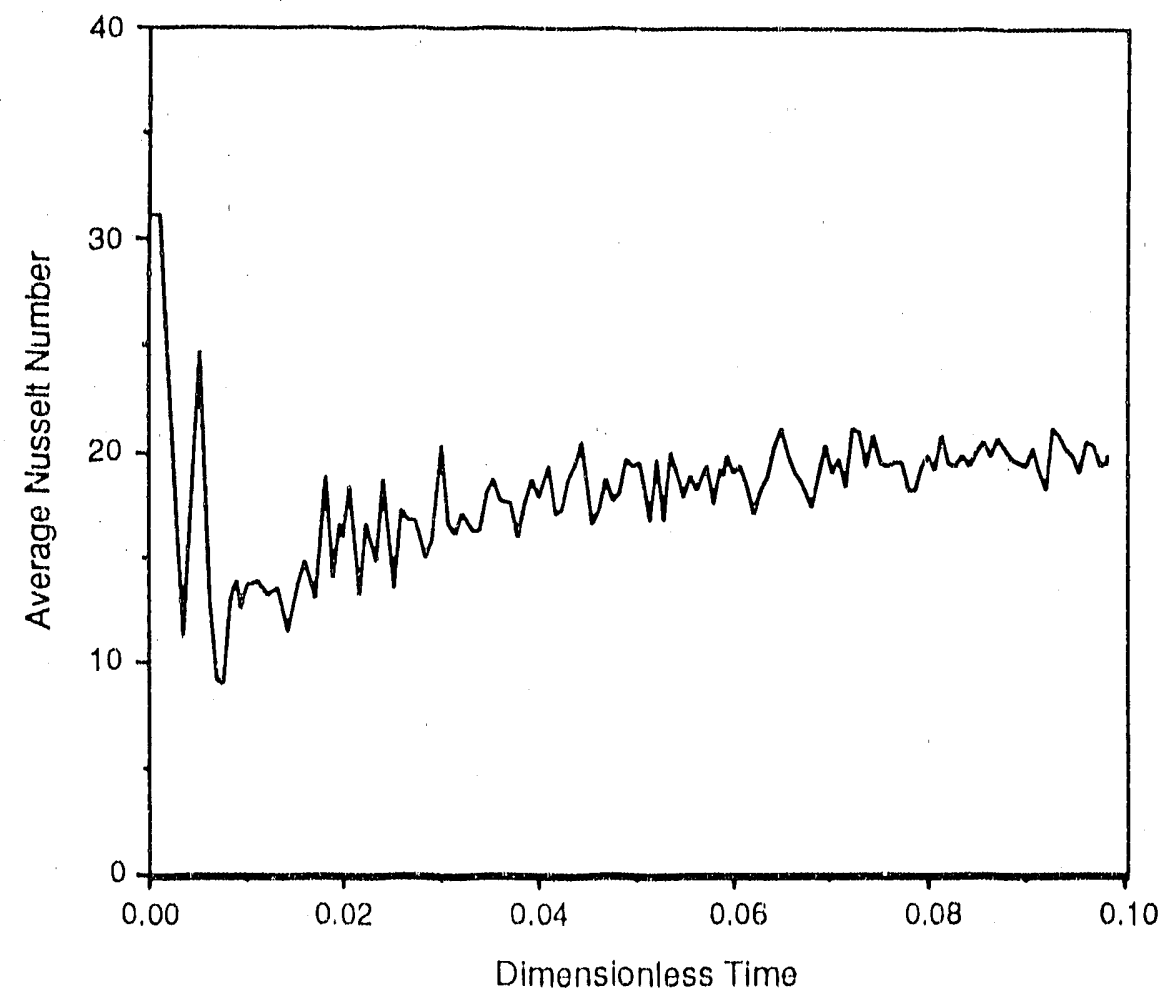

Figure 27. MAGMA calculated transient response of the average Nusselt number. 


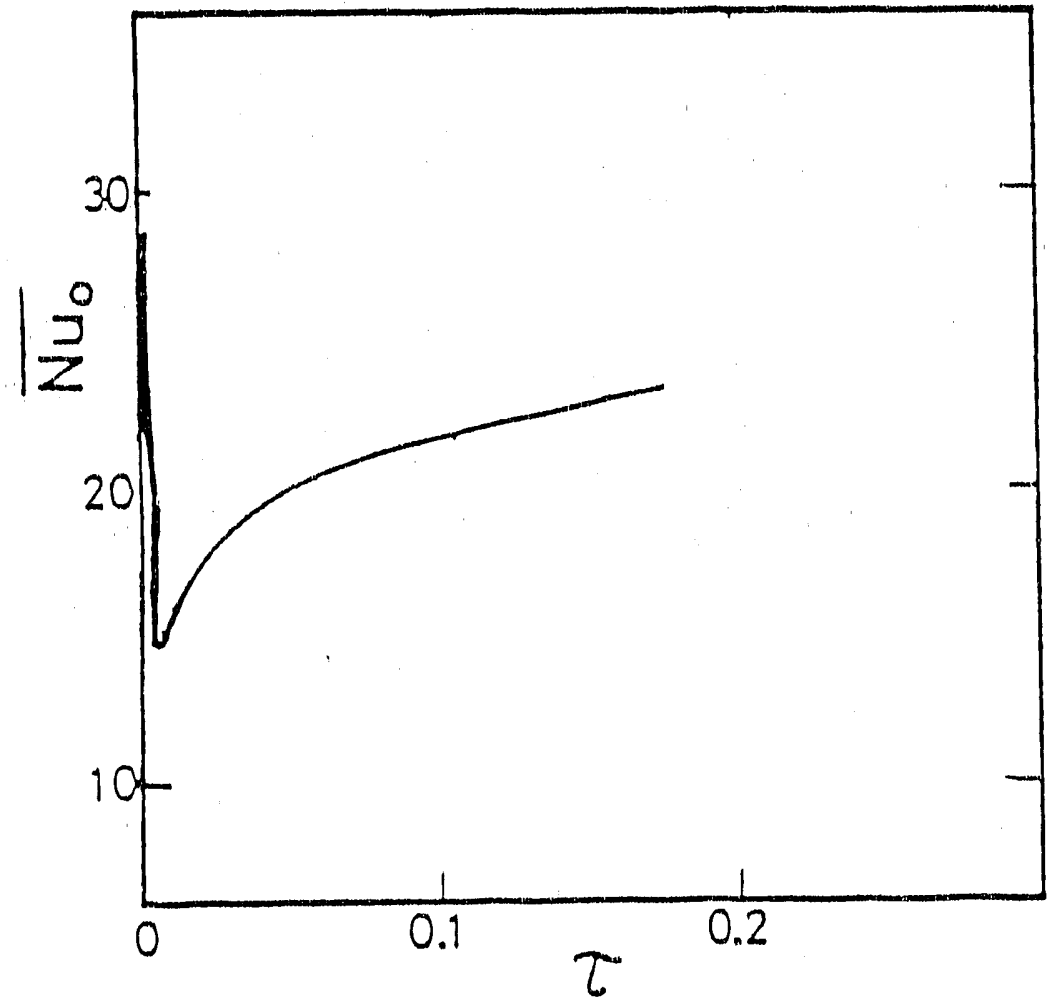

Figure 28. Reference 14 calculated transicnt response of the average Nusselt number. 


\section{SUMMARY AND RECOMMENDATIONS FOR FURTHER CODE DEVELOPMENT}

MAGMA is a three-dimensional finite difference computer code designed to simulate fluid flow and heat transfer in ISV melt poots. The equations governing fluid flow are the incompressible Navier-Stokes equations, Heat transfer is governed by the energy equation.

Energy is related to temperature through an equation of state that includes melting. The momentum ecuation is coupled to the temperature field through the Boussinesg model approximations. 'The coupled governing equations can be solved simultaneously, or the incompressible Navier-Stokes equations can be solved separately in the absence of heat transfer. All fluid properties in MAGMA are assumed variable except density. Fluid density is allowed to vary only in the buoyancy terms of the momentum equation.

MAGMA has been tested against the results of many numerical and analytical test problems. MAGMA has demonstrated the capability to simulate two dimensional advection, two dimensional conduction, two and three dimensional natural convection, and natural convection d:iring melting.

Recommendations for further investigation and development of the MAGMA code include:

- Conversion of the explicit temporal differencing of the energy equation to a fully implicit differencing scheme.

- Addition of a Joule heating model.

- Optimization of the iteration parameters.

- Investigation and determination of optumum convergence criteria for the iterative solution.

- Modification of the variable viscosity formulation to eliminate artificial time step restrictions arising when this option is selected.

- Assessment of MAGMA against ISV test data. 
It is anticipated that the above recommendations could be readily implemented, and have the polential to significantly enhance code performance. 


\section{REFERENCES}

1. L. D. Landau and E, M. Lifshitz, Fluid Mechanics 2nd edition, 6, 1987.

2. R. Peyret and T. D. Taylor, Computational Methods for Fluid Flow, SpringerVerlag, New York, 1983.

3. J. D. Ramshaw and V. A. Mousseuu, "Accelerated Artificial Compressibility Method for Steady-Stute Incompressible Flow Calculatlons," Computers \& F'luids, 18,1990, p. 361 .

4. J. D. Ramshaw and J. K. Dukowicz, APACHE: A Generalized-Mesh Eulerian Computer Code for Multicomponent Chemically Reactive Fluid Flow, Los Alamos Scientific Laboratory, LA-7427, 1979.

5. F. P. Incropera and D. P. DeWitt, Introduction to Heat Transfer 2 nd edition., John Wlley \& Sons, New York, 1990.

6. W. H. Soh and J. W. Goodrich, "Unsteady Solution of Incompressible NavierStokes Equations," Journal of Computational Physics, 79, 1984, p.113.

7. U. Gia, et. al., "High-Re Solutions for Incompressible Flow Using the NavierStokes Equations and a Multigrid Mothod," Journal of Computational Physics 48, 1982, pp. 387-411.

8. D. L. Powers, Boundary Value Problems, Academic Press, 1979, p. 205.

9. H. S. Carslaw and J. C. Jaeger, Conduction of Heat in Solids 2 nd edition., Clarendon Press, 1959.

10. J. E. Fromm, "Numerical Solution of the Nonlinear Equations for a Heated Fluid Layer," Physics of Fluids', 8, 1965, pp. 1757-69.

11. J. S. Turner, Buoyancy Effects in Fluids, Cambridge University Press, New York, 1973.

12. G. De Vahl Davis, "Natural Convection of Air in a Square Cavity: A Benchmark Numerical Solution," International Journal of Numerical Methods in Fluids', 3, 1983, pp. 249-264.

13. A. M. C. Chan and S. Banerjee, "A Numerical Study of Three-Dimensional Roll Cells Within Rigid Boundaries," Journal of Heat Transfer, 101, 1979, p. 233.

14. Masashi Okada, "Heat Transfer During Melting Around a Vertical Cylinder (Effects of Aspect Ratio of the Cylinder and Subcooling)," JSME Intermational Journal, 30, 1987, pp. 1430-1436. 


\section{APPENDIX A}

AVERAGING TECHNIQUES

A. 1 


$$
\text { A. } 2
$$




\section{APPENDIX A}

\section{AVERAGING TECHNIQUES}

This appendix describes the averaging procedure used in the MAGMA code. MAGMA uses a staggered grid in which some variables are located at cell centers and others are located at the centers of cell faces. Frequently, values of certain variables are needed at locations where they arc not explicitly defined. Since MAGMA ussumes a uniform mesh, simple averaging can be used to obtuin these values.

Values of cell centered quantities are often needed on cell faces or on cell edges. The value of the quantity at these locations is obtained by averaging the quantity values located at the centers of the active cells immediately adjacent to that cell face or edge. Consider Figure A.1 as an example, which shows four active cells in the $x-y$ plane (the $z$-dlrection is out of the paper). In this figure, the quantity, $q$, is a cell centered quantity. The value of $q$ on the right (subscript $R$ ) face of cell $(i, j, k)$ is computed by averaging the value of $q$ in cell $(i, j, k)$ and cell $(i+1, j, k), i e .$,

$q_{R}=\frac{1}{2}(q i j, k+q i+1, k)$

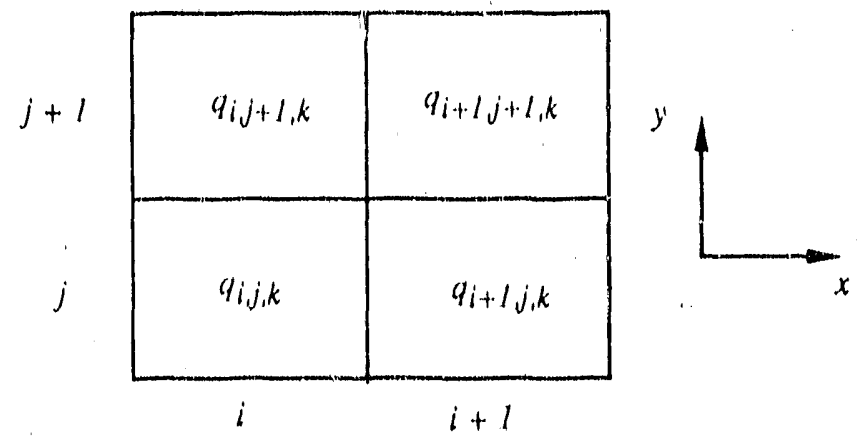

Figure A-1. Four active cells in the $x-y$ plane. 
Similarly, the value of $q$ on the right-front (subscript $R F$ ) edge of cell $(i, j, k)$ is given by

$q_{R F}=\frac{1}{4}\left(q_{i, j, k}+q_{i+1, j, k}+q_{i+1, j+l, k}+q_{i, j+1, k}\right)$

Velocity components, which live on cell faces, are often needed on cell edges, cell centers, and on other cell faces where they are not explicitly defined. Consider Figure A-2 as an example, which is a schematic of two active cells in the $x$-y plane. Only the $u$-velocity

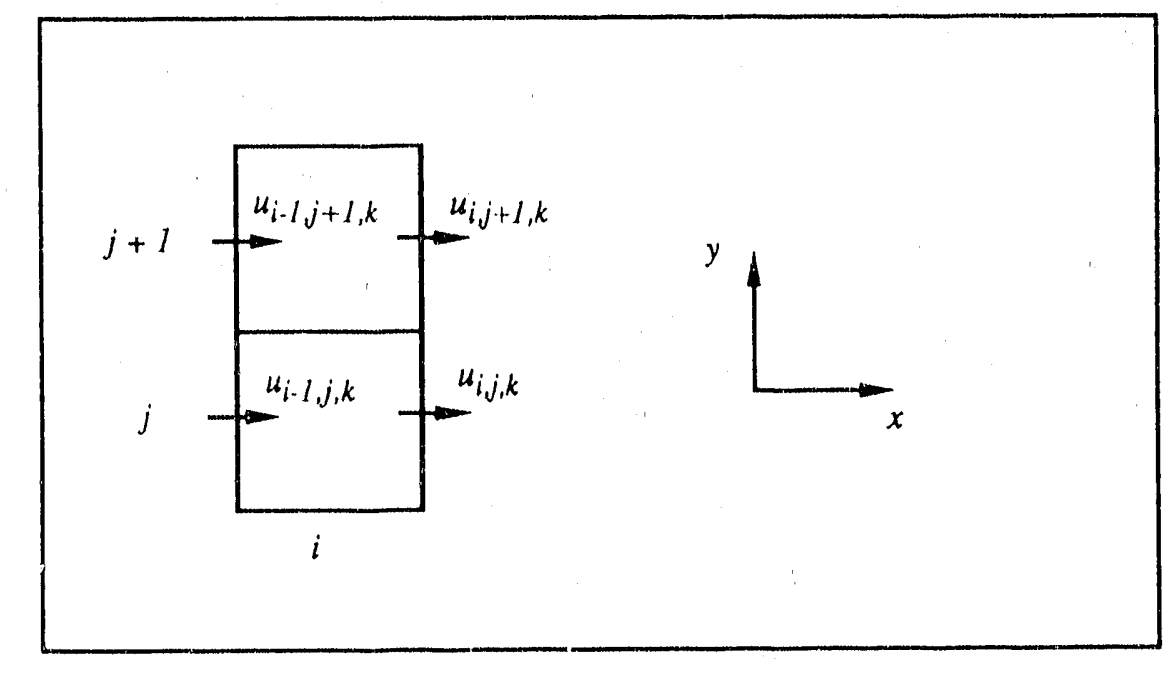

Figure A-2. Two active cells in the $x-y$ plane.

components are shown in this figure for simplicity. The value of $u$ at the center (subscript $C$ ) of cell $(i, j, k)$ is calculated by

$u_{C}=\frac{1}{2}\left(u_{i, j, k}+u_{i-1, j, k}\right)$

The value of $u$ on the right-front (subscript $R F$ ) edge is computed from

$u_{R F}=\frac{1}{2}\left(u_{i, j, k}+u_{i, j+1, k}\right)$ 
The value of $u$ on the front (subscript $F$ ) cell face is obtained from

$u_{F}=\frac{1}{4}\left(u_{i j, k}+u_{i, j+1, k}+u_{i-1, j+1, k}+u_{i-1, j, k}\right)$

The other two velocity components are averaged in a similar fashion.

A-5 


\section{APPENDIX B}

\section{WEIGHTED AVERAGING OF CENTERED}

AND UPWINDED VALUES 
B - 2 


\section{APPENDIX B \\ WEIGHTED AVERAGING OF CENTERED AND UPWINDED VALUES}

This appendix describes, by example, how a quantity, $q$, is computed from a weighted average of its centered, $q_{c}$, and its "upwinded" value, $q_{u}$, at a given location. Figure B.1 is a schematic of two computational cells in the $x-y$ plane. The quantity, $q$, is being convected by the velocity, $u$, and is to be computed on the interface
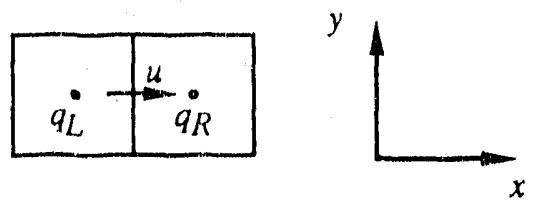

Figure B-1. Two computational cells in the $x-y$ plane.

between the two cells. $q_{L}$ is the value of $q$ at the center of the left cell, while $q_{R}$ is the value of $\mathrm{q}$ at the center of the right cell. Note that the necessary variables may have to be calculated at the required locations using the averaging techniques described in Appendix A.

The "upwinded" value of $q$ in Figure A- 1 is $q_{L}$. Note, that if the direction of $u$ is reversed, the "upwinded" value of $q$ is $q_{R} . q_{U}$ is thus given by

$q_{u}=\left\{\begin{array}{ll}q_{L}, & u>0 \\ q_{R}, & u<0\end{array}\right\}$

The centered value of $q$ on the interface is simply the average of $q_{L}$ and $q_{R}$.

$q_{C}=\frac{1}{2}\left(q_{L}+q_{R}\right)$ 
The weighted average of the centered value of $q$ and the upwinded value of $q$ on the interface between the cells is computed from

$q=\alpha q u+(1-\alpha) q_{c}$

where $\alpha$ represents the firaction of upwinding, and $(1-\alpha)$ represents the fraction of centering. For stability of the iteration scheme, $\alpha$ must exceed the greater of $\frac{|u| \Delta \tau}{\Delta x}, \frac{|v| \Delta \tau}{\Delta y}$, and $\frac{|w| \Delta \tau}{\Delta z}$. For stability of the energy equation, $\alpha$ must exceed the greater of $\frac{|u| \Delta t}{\Delta x}, \frac{|v| \Delta t}{\Delta y}$, and $-\frac{|w| \Delta t}{\Delta z}$. 


\section{APPENDIX C}

VARIABLE AND SUBROUTINE DICTIONARY 


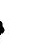

C. 2 


\section{APPENDIX C}

\section{VARIABLE AND SUBROUTINE DICTIONARY}

\section{VARIABLES}

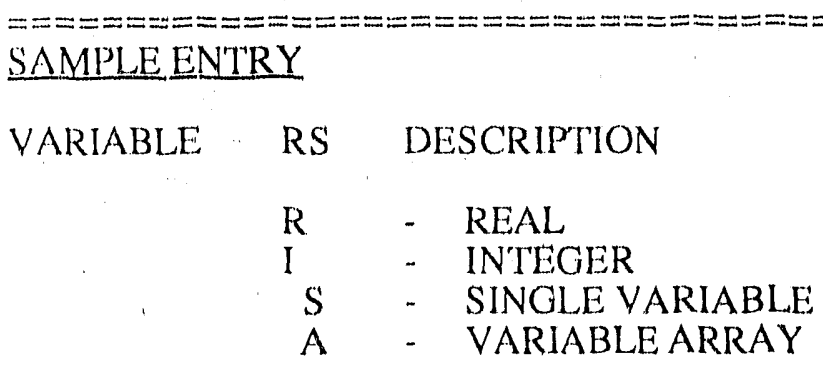

\begin{tabular}{|c|c|c|}
\hline \multirow[t]{3}{*}{ ALPHA } & RS & UPWIND/CENTER-DIFFERENCING WEIGHTING FUNCTION \\
\hline & & $=0$ MEANS CENTERED DIFFERENCING \\
\hline & & $=1$ MEANS $\quad$ UPWIND DIFFERENCING \\
\hline \multirow[t]{2}{*}{ ALLHHD } & RS & INTERPOLATED DONOR CELL DIFFERENCING WEIGHTING \\
\hline & & PARAMETER (FRACTION DONOR CELL DIFF.) \\
\hline$\triangle S Q R$ & RS & WAVE PARAMETER, SQUARE OF WAVE SPEED \\
\hline BETA & RS & MULTIPLIER, D*BETA/OMG IS DELP. IT INCLUDES OMG. \\
\hline \multirow{2}{*}{ BETAID } & RS & INTERPOLATED DONOR CELL DIFF. PARAMETER \\
\hline & & (FRACTION INTERPOLATED DONOR CELL DIFF.) \\
\hline BCTE & RS & BETA, COEFF, OF THERMAL EXPANSION \\
\hline$B F X$ & RS & BUOYANCY FORCE IN THE X-DIRECTION \\
\hline BFY & RS & BUOYANCY FORCE IN THE Y-DIRECTION \\
\hline$B F Z$ & RS & BUOYANCY FORCE IN THE Z-DIRECTION \\
\hline $\mathrm{C}$ & $\mathrm{Cl}$ & FIRST CHARACTER FROM A LINE OF INPUT DATA \\
\hline CREU & RS & CELL REYNOLDS NUMBER BASED ON U-VELOCITY \\
\hline CREV & RS & CELLL REYNOLDS NUMBER BASED ON V-VEI.OCITY \\
\hline CREW & RS & CELL REYNOLDS NUMBER BASED ON W-VELOCITY \\
\hline CRXI8 & $\mathrm{RS}$ & MULTIPLIER USED IN RZ GEOMETRY MOMENTUM EQUATION \\
\hline CRXIH8 & RS & MULTIPLIER USED IN RZ GEOMETRY MOMENTUM EQUATION \\
\hline $\mathrm{CF}$ & RA & SPECIFIC HEAT CAPACITY ARRAY \\
\hline CVREF & RS & REFERENCE SPECIFIC HEAT CAPACITY \\
\hline
\end{tabular}




\begin{tabular}{|c|c|c|}
\hline CVMAX & RS & MAXIMUM SPECIFIC HEAT VALUE IN REGION \\
\hline CWPR'T & RS & $\begin{array}{l}\text { THE INCREMENT OF CUMULATIVE TIME BETWEEN PLOT-IIMI: } \\
\text { WRITES }\end{array}$ \\
\hline CWPRT & RS & $\begin{array}{l}\text { THE INCREMENT OF CUMULATIVE TIME BETWEEN DETAILED } \\
\text { EDITS }\end{array}$ \\
\hline CYCLE & IS & THE NUMBER OF TIME STEPS TAKEN THUS FAR \\
\hline CYL & RS & CYLINDRICAL/RECTANGULAR COORD SYSTEM SWITCH \\
\hline & & $\begin{array}{lll}=\text { DP( }) & \text { MEANS } & \text { RETANGULAR } \\
=\text { DP1 } & \text { MEANS } & \text { CYLINDRICAL }\end{array}$ \\
\hline D & RS & $\begin{array}{l}\text { THE DISCRETE DIVERGENCE OF THE VELOCITY FIELD AS } \\
\text { MEASURED AT THE CENTER OF THE CURREN'T CELL }\end{array}$ \\
\hline DALPH & RS & THERMAL DIFFUSIVITY \\
\hline DELP & RS & THE PRESSURE UPDATE FOR THE CURRENT CELL \\
\hline DELT & RS & TIME STEP \\
\hline DELTUB & RS & $\begin{array}{l}\text { UPPER LIMIT FOR THE TIME S'TEP BASED ON VELMX } \\
=\text { MIN (!DX/U!, IDY/V!, (DX*DY)**2/(2*NU*(DX**2+DY**2))) }\end{array}$ \\
\hline DELX & RS & X-DIRECTION MESH-SPACING' \\
\hline DELY & RS & Y-DIRECTION MESH-SPACING \\
\hline DIFFMX & RS & MAXIMUM VALUE OF THE THERMAL DIFFUSIVITY \\
\hline DIFFX & RS & TEMPERATURE DIFTUSION TERM (X-DIRECTION) \\
\hline DIFFY & RS & TEMPERATURE DIFFUSION TERM (Y-DIRECTION) \\
\hline DIFFZ & RS & TEMPERATURE DIFFUSION TERM (Z-DIRECTION) \\
\hline DP() & RS & VARIABLE HOLDING REAL ZERO (DBL PREC) \\
\hline DP1 & RS & VARIABLE HOLDING REAL ONE (DBL PREC) \\
\hline DP1P2 & RS & VARIABLE HOLDING REAL ONE POINT TWO (DBL PREC) \\
\hline DP1P5 & RS & VARIABLE HOLDING REAL ONE POINT FIVE (DBL PREC) \\
\hline DP2 & RS & VARIABLE HOLDING REAL TWO (DBL PREC) \\
\hline DP8 & RS & VARIABLE HOLDING REAL EIGHT (DBL PREC) \\
\hline DTDXL & RS & DERIVATIVE OF T WRT X ON THE LEFT CELL FACE \\
\hline DTDXR & RS & DERIVATIVE OF T WRT X ON THE RIGHT CELL FACE \\
\hline DTDYF & RS & DERIVATIVE OF T WRT X ON THE FRONT CELL FACE \\
\hline DIDYD & RS & DERIVATIVE OF T WRT X ON THE DERRIERE CELL FACE \\
\hline DTDZB & RS & DERIVATIVE OF T WRT X ON THE BOTTOM CELL FACE \\
\hline DTDET & RS & DERIVATIVE OF T WR'T X ON THE TOP CELL FACE \\
\hline D'TU & RS & ARTIFICIAL TIME STEP \\
\hline DUB & RS & DIFFERENCE BETWEEN U(I,J,K) AND ITS BOTTOM NEIGHBOIR \\
\hline
\end{tabular}




\begin{tabular}{|c|c|c|}
\hline DUD & RS & DIFFERENCE BETWEEN U(I,J,K) AND IT'S DERRIERE NEIGHBOR \\
\hline DUDXR & RS & $\begin{array}{l}\text { DERIVATIVE OF U WRT X ON THE RIGHT FACE OF THE } \\
\text { X-MOMENTUM CELL }\end{array}$ \\
\hline DUDXL & RS & $\begin{array}{l}\text { X-MOMENTUM CELL } \\
\text { DERIVATIVE OF U WRT X ON THE LEFT FACE OF THE } \\
\text { X-MOMENTUM CELL }\end{array}$ \\
\hline DUDYLF & RS & DERIVATIVE OF U WRT Y ON THE LEFT-FRONT CELL EDGE \\
\hline DUDYRF & RS & DERIVATIVE OF U WRT Y ON THE RIGHT-FRONT CELL EDGE \\
\hline DUDYRD & RS & $\begin{array}{l}\text { DERIVATIVE OF U WRT Y ON THE RIGHT-DERRIERE CELL } \\
\text { EDGE }\end{array}$ \\
\hline DUDZLT & RS & DERIVATIVE OF U WRT Z ON THE LEFT-TOP CELL EDGE \\
\hline DUDZRT & RS & DERIVATIVE OF U WRT Z ON THE RIGHT-TOP CELL EDGE \\
\hline DUDYRB & RS & DERIVATIVE OF U WRT Z ON THE RIGHT-BOTTOM CELL EDGE \\
\hline DUEDX & RS & $\begin{array}{l}\text { CONVECTIVE TERM IN ENERGY EQ. } \\
\text { DERIVATIVE OF (UE) WR'T X }\end{array}$ \\
\hline DUF & RS & $\begin{array}{l}\text { DERIVATIVE OF (UE) WR'T X } \\
\text { DIFFERENCE BETWEEN U(I,J,K) AND ITS FRONT NEIGHBOR }\end{array}$ \\
\hline DUL & RS & DIFFERENCE BETWEEN U(I,J,K) AND ITS LEFT NEIGHBOR \\
\hline DUR & RS & DIFFERENCE BETWEEN U(I,J,K) AND ITS RIGHT NEIGHYBOR \\
\hline DUT & RS & DIFFERENCE BETWEEN U(I,J,K) AND ITS TOP NEIGHBOR \\
\hline DVB & RS & DIFFERENCE BETWEEN V(I,J,K) AND ITS BOTTOM NEIGHBBOR \\
\hline DVD & R.S & DIFFERENCE BETWEEN V(I,J,K) AND ITSS DERRIERE NEIGHBOR \\
\hline DVDXDR & RS & $\begin{array}{l}\text { DERIVATIVE OF V WRT X ON THE DERRIERE-RIGHT CELL } \\
\text { EDGE }\end{array}$ \\
\hline VDXFR & RS & DERIVATIVE OF $V$ WRT $X$ ON THE FRONT-RIGHT CELL EDGE \\
\hline VDXFL & RS & DERIVATIVE OF V W'RT X ON THE FRONT-LEFT CELL EDGE \\
\hline DVDYD & RS & $\begin{array}{l}\text { DERIVATIVE OF V WRT Y ON THE DERRIERE FACE OF THE } \\
\text { Y-MOMENTUM CELL }\end{array}$ \\
\hline DVDYF & RS & $\begin{array}{l}\text { DERIVATIVE OF } \vee \text { WRT Y ON THE FRONT FACE OF THE } \\
\text { Y-MOMENTUM CELL }\end{array}$ \\
\hline VDZDT & TS & DERIVATIVE OF Y WRT Z ON THE DERRIERE-TOP CELL EDGE \\
\hline DVDZFB & TS & DERIVATIVE OF V WR'T Z ON THE FRONT-BOTTOM CELL EDGE \\
\hline DVDZFT & TS & DERIVATIVE OF V WRT Z ON THE FRONT-TOP CELL EDGE \\
\hline DVF & RS & DIFFERENCE BETWEEN V(I,J,K) AND ITS FRONT NEIGHBOR \\
\hline DVL & RS & DIFFERENCE BETWEEN V(I,J,K) AND ITS LEFT NEIGHBOR \\
\hline DVR & RS & DIFFERENCE BETWEEN V(I,J,K) AND ITS RIGHT NEIGHBOR \\
\hline DVT & RS & DIFFERENCE BETWEEN V(I,J,K) AND ITS TOP NEIGHBOR \\
\hline DWB & RS & DIFFERENCE BETWEEN W(I,J,K) AND ITS BOTTOM NEIGHBOR \\
\hline
\end{tabular}
C. 5 
DWD

$\begin{array}{ll}\text { DWDXBR } & \text { RS } \\ \text { DWDXBF } & \text { RS } \\ \text { DWDXTR } & \text { RS } \\ \text { DWDYBF } & \text { TS } \\ \text { DWDYTD } & \text { TS } \\ \text { DWDYTF } & \text { TS } \\ \text { DWDZB } & \text { RS }\end{array}$

DWDZT

DVEDX

DWEDX

DWF

DWL

DWR

DWT

DZEPS

DZRO

E

ECOEFF1

ECOEFF2

ENLOOP

ENTIME

EPSI

FK

FKB

FKD

FKF

FKL

FKMAX

RS

RS

RS RS
RS DIFFERENCE BETWEEN W(I,J,K) AND ITS DERRIERE NEIGHBOR

RS DERIVATIVE OF.W WRT X ON THE BOTTOM-RIGHT CELL EDGE DERIVATIVE OF W WRT $X$ ON THE BOTTOM-FRONT CELL EDGE DERIVATIVE OF W WRT X ON THE TOP-RIGHT CELL EDGE DERIV ATIVE OF W WRT Y ON THE BOTTOM-FRONT CELL. EDGL DERIVATIVE OF W WRT Y ON THE TOP-DERRIERE CELL EDGE DERIVATIVE OF W WRT Y ON THE TOP-FRONT CELL EDGE DERIVATIVE OF W WRT Z ON THE BOTTOM FACE OF THE Y-MOMENTUM CELL

DERIVATIVE OF W WRT Z ON THE TOP FACE OF THE Y-MOMENTUM CELL

RS CONVECTIVE TERM IN ENERGY EQ. DERIVATIVE OF (VE) WR'T X

RS CONVECTIVE TERM IN ENERGY EQ. DERIVATIVE OF (WE) WRT X

DIFFERENCE BETWEEN W(I,J,K) AND ITS FRONT NEIGHBOR

DIFFERENCE BETWEEN W(I,J,K) AND ITS LEFT NEIGHBOR

RS DIFFERENCE BETWEEN W(I,J,K) AND ITS RIGHT NEIGHBOR

RS DIFFERENCE BETWEEN W(I,J,K) AND ITS TOP NEIGHBOR

DZRO*EPSI, THE LARGEST TOLERABLE VALUE OF D IN ANY CELL

RS BENCHMARK VALUE OF D

RA ENERGY ARRAY

RS LINEAR COEFF, IN EQ. OF STATE RELATING TEMP. TO ENERGY

RS QUADRATIC COEFF. IN EQ. OF STATE RELATING TEMP. TO ENERGY

RS

TIME ON THE INTERNAL CLOCK AT THE END OF LOOP

TIME ON INTERNAL CLOCK AT END OF RUN

RS CONVERGNCE TOLERANCE FOR THE SOR ITERATION

RA THERMAL CONDUCTIVITY ARRAY

RS THERMAL CONDUCTIVITY ON THE BOTTOM CELL FACE

RS THERMAL CONDUCTIVITY ON THE DERRIERE CELL FACE

RS THERMAL CONDUCTIVITY ON THE FRONT CELL FACE

RS THERMAL CONDUCTIVITYY ON THE LEFT CELL FACE

RS MAXIMUM VALUE OF TIIE THERMAL CONDUCTIVITY

C- 6 


\begin{tabular}{|c|c|c|}
\hline FKR & RS & THERMAL CONDUCTIVITY ON THE RIGHT CELLL FACE \\
\hline FKREF & RS & REFERENCE THERMAL CONDUCTIVITY \\
\hline FK'T & RS & THERMAL CONDUCTIVITY ON THE BOTTOM CELL FACE \\
\hline FL & RS & LATENT HEAT OF FUSION \\
\hline FLCHAR & RS & CHARACTERISTIC LENGTH \\
\hline FLG & RS & CONVERGNCE CONDITION ATTAINMENT FL,AG: \\
\hline & & $\begin{array}{l}\text { FLG }=\text { DP1 MEANS } \\
\text { IN SOME }\end{array}$ \\
\hline & & $\begin{array}{l}\text { FLG }=\text { DPO MEANS } \quad \text { CONVERGENCE CONDITION } \\
\text { ATTAINED. }\end{array}$ \\
\hline FUC & RS & $\begin{array}{l}\text { WEJGHTED AVERAGE OF CENTERED AND UPWIND } \\
\text { DIFFERENCING IN THE RZ SUMMAND OF THE CONVECTIVE, } \\
\text { TERM OF THE U-DIRECTION MOMENTUM EQUATION }\end{array}$ \\
\hline FuX & RS & $\begin{array}{l}\text { WEIGHTED AVERAGE OF CENTERED UPWIND DIFFERENCING } \\
\text { IN THE D(U**2)/DX SUMMAND OF THE CONVECTIVE TERM OF' } \\
\text { THE U-DIRECTION MOMENTUM EQUA'TION }\end{array}$ \\
\hline FUY & RS & $\begin{array}{l}\text { WEIGHTED AVERAGE OF AND UPWIND DIFFERENCING } \\
\text { IN THE D(UV)/DX SUMMAND OF THE CONVECTIVE TERM OF } \\
\text { THE U-MOMENTUM EQUATION }\end{array}$ \\
\hline FUZ & RS & $\begin{array}{l}\text { WEIGHTED AVERAGE OF CENTERED AND UPWIND } \\
\text { DIFFERENCING IN THE D(UW)/DZ SUMMAND OF THE } \\
\text { CONVECTIVE TERM OF THE U-DI MOMENTUM EQUATION }\end{array}$ \\
\hline FVC & RS & $\begin{array}{l}\text { WEIGHTED A VERAGE OF CENTERED AND UPWIND } \\
\text { DIFFERENCING IN THE RZ SUMMAND OF THE CONVECTIVE } \\
\text { TERM OF THE V-DIRECTIO MOMENTUM EQUATION }\end{array}$ \\
\hline $\mathrm{FVX}$ & RS & $\begin{array}{l}\text { WEIGHTED AVERAGE OF CENTERED AND UPWIND } \\
\text { DIFFERENCING IN THE D(UV)/DX SUMMAND OF THE } \\
\text { CONVECTIVE TERM OF THE V-DIRECTION MOMENTUM } \\
\text { EQUATION }\end{array}$ \\
\hline FVY & RS & $\begin{array}{l}\text { WEIGHTED AVERAGE OF CENTERED AND UPWIND } \\
\text { DIFFERENCING IN THE D }\left(\mathrm{V}^{* *} 2\right) / D X \text { SUMMAND OF THE } \\
\text { CONVECIIVE TERM OF THE V-DIRECTION MOMENTUM } \\
\text { EQUATION }\end{array}$ \\
\hline
\end{tabular}


FV'Z

FWC

FWX

FWY

FWZ

GX

GY

$\mathrm{GZ}$

I

IBAR

ID

IDBC

IENERGY IS
RS WEIGHTED AVERAGE OF CENTERED AND UPWIND DIFFERENCING IN THE D(VW)/DZ SUMMAND OF THE CONVECTIVE TERM OF THE V-DIRECTION MOMENTUM EQUATION

RS WEIGHTED AVERAGE OF CENTERED AND UPWIND DIFFERENCING IN THE RZ SUMMAND OF THE CONVECTIVE TERM OF THE W-DIRECTION MOME' 'TUM EQUA'TION

RS WEIGHTED AVERAGE OF CENTERED AND UPWIND DIFFERENCING IN THE D(UW)/DX SUMMAND OF THE CONVECTIVE TERM OF THE W-DIRECTION MOMENTUM EQUATION

RS WEIGHTED AVERAGE OF CENTERED AND UPWIND DIFFERENCING IN THE D(VW)/DY SUMMAND OF THE CONVECTIVE TERM OF THE W-DIRECTION MOMENTUM EQUATION

RS WEIGHTED A VERAGE OF CENTERED AND UPWIND DIFFERENCING IN THE $D(W * * 2) / D Z Z$ SUMMAND OF THE CONVECTIVE TERM OF THE W-DIRECTION MOMENTUM EQUATION

RS X-DIRECTION COMPONENT OF GRAVITATIONAL FORCE

RS Y-DIRECTION COMPONENT OF GRAVITATIONAL FORCE

RS Z-DIRECTION COMPONENT OF GRAVITATIONAL FORCE IS DO-LOOP INDEX IBAR

IS NUMBER OF MESH CELLS IN THE X-DIRECTION IN THE REGION

IA INDIRECT ADDRESSING ARRAY FOR ALL INTERIOR CELLS $\operatorname{ID}(1, N) \Rightarrow$ I INDEX FOR Nth CELL

ID $(2, N) \Rightarrow$ J INDEX FOR Nth CELL.

$\operatorname{ID}(3, \mathrm{~N}) \Rightarrow \mathrm{K}$ INDEX FOR Nth CELL

IA INDIRECT ADDRESSING ARRAY FOR ALL BOUNDARY CELLS $\operatorname{IDBC}(1, N) \Rightarrow$ I INDEX FOR Nth CELL $\operatorname{IDBC}(2, N) \Rightarrow$ J INDEX FOR Nth CELL $\operatorname{IDBC}(3, N) \Rightarrow \mathrm{K}$ INDEX FOR Nth CELL

IS ENERGY SOLVER FLAG, $=1$ SOLVE ENERGY EQ $=0$ NO ENERGY EQ. 
IFIMP

IGUESS

IM1

IM2

IMAP

IMAX

IMELT

IMLT

INDEX

IOIN

IOOUT

IOPLT

IPRS

IRIN

IROUT

ISTART

ISTOP

[STRM]

ITER
IS

FLAG DETERMINING FULLY/LINEARLYY IMPLICIT OPTION

$=1=\Rightarrow$ LINEARLY IMPLICIT

$=0=\Rightarrow$ FULLY IMPLICIT

IS FLAG DETERMINING INITIAL GUESS FOR FLOW VELOCITY

$=0==>$ EXPLICIT APPROX. TO MOM. E.Q

$=1 \Rightarrow$ EXTRAPOLATION FROM PREV. 2 TIME LEVELS

$=2=\Rightarrow$ PREVIOUS TIMIE VELOCITY

IS

IS

IA

IMAX-1

IMAX-2

INDIRECT ADDRESSING ARRAY (4 DIMENSIONAL)

$\operatorname{IMAP}(\mathrm{I}, \mathrm{J}, \mathrm{K}, 1)=0 \Rightarrow$ CELL $(\mathrm{I}, \mathrm{J}, \mathrm{K})$ IS INACTIVE

$\operatorname{IMAP}(\mathrm{I}, \mathrm{J}, \mathrm{K}, 1)=1 \Rightarrow$ CELL $(\mathrm{I}, \mathrm{J}, \mathrm{K})$ IS ACTIVE

$\operatorname{IMAP}(\mathrm{I}, \mathrm{J}, \mathrm{K}, 2)=0 \Rightarrow$ BOUNDARY CELL $(\mathrm{I}, \mathrm{J}, \mathrm{K})$ IS A NO-SLIP WALL

$\operatorname{IMAP}(I, J, K, 2)=1 \Rightarrow$ BOUNDARY CELL $(\mathrm{I}, \mathrm{J}, \mathrm{K})$ IS A FREE-SLIP WALL

$\operatorname{IMAP}(\mathrm{I}, \mathrm{J}, \mathrm{K}, 2)=2 \Rightarrow$ BOUNDARY CELL $(\mathrm{I}, \mathrm{J}, \mathrm{K})$ IS A WALL WITH SPECIFIED VELOCITIFS

IS

IS

IS

IS

IS

IS

IS

IS

IS

IS

IS

IS

IS

IS

NUMBER OF CELLS IN TH A X-DIRECTION OF THE AUGMENTED REGION INCLUDES THE BOUNDARY CELLS.

MELTING FLAG - IMELT $=0$, NO MELTING - IMELT $=1$, MELTING IS ALLOWED

LOGICAL UNIT NUMBER FOR THE MEI 'T FRONT DATA FILE "mildat"

USED TO COMBINE THE CONTINUATIVE AND PERIODIC B. C. LOOPS

LOGICAL UNIT NUMBER FOR THE INPUT DEVICE LOGICAL UNIT NUMBER FOR OUTPUT FILE "outdat" LOGICAL UNIT NUMBER FOR OUTPUT FILE "pltdat" LOGICAL UNIT NUMBER FOR PRESSURE DATA FILE "prsdat" LOGICAL UNIT NUMBER FOR THE RESTART INPUT DEVICE LOGICAL UNIT NUMBER FOR THE RESTART OUTPUT DEVICE STARTING VALUE FOR DO-LOOP WITH INDEX I STOPPING VALUE FOR DO-LOOP WITH INDEX I ISTART - I

NUMBER OF SOR ITERATIONS TAKEN ON A TIME STEP

$$
\text { C. } 9
$$


ITMP

ITMPB

ITMPD

ITMPF

ITMPL

ITSUM

IVEL

IVISC

$\mathrm{J}$

JBAR

JM1

JM2
IS LOGICAL UNIT NUMBER FOR TEMPERATURE DATA FILE "tmpdat"

IS BOTTOM TEMP. BOUNDARY COND. FLAG

$=1$ CONSTANT TEMP.

$=2$ CONSTANT HEAT FLUX/SYMETRIC/ADIABATIC

$=3$ CONVECTIVE/MIXED B.C.

IS DERRIERE TEMP. BOUNDARY COND. FLAG

$=1$ CONSTANT TEMP.

$=2$ CONSTANT HEAT FLUX/SYMETRIC/ADIABATIC

$=3$ CONVECTIVE/MIXED B.C.

IS FRONT TEMP. BOUNDARY COND. FLAG

$=1$ CONSTANT TEMP.

$=2$ CONSTANT HEAT FLUX/SYMETRIC/ADIABATIC

$=3$ CONVECTIVE/MIXED B.C.

IS LEFT TEMP. BOUNDARY COND. FLAG

$=1$ CONSTANT TEMP.

$=2$ CONSTANT HEAT FLUX/SYMETRIC/ADIABATIC

$=3$ CONVECTIVE/MIXED B.C.

IS RIGHT TEMP. BOUNDARY COND. FLAG

$=1$ CONSTANT TEMP.

$=2$ CONSTANT HEAT FLUX/SYMETRIC/ADIABATIC

$=3$ CONVECTIVE/MIXED B.C.

IS TOP TEMP. BOUNDARY COND. FLAG

$=1$ CONSTANT TEMP.

$=2$ CONSTANT HEAT FLUX/SYMETRIC/ADIABATIC

$=3$ CONVECTIVE/MIXED B.C.

IS THE TOTAL NUMBER OF ITERATIONS TAKEN ON ALL CYCLES

IS LOGICAL UNIT NUMBER FOR THE VELOCITY DATA FILE "veldat"

IS VARIABLE VISCOSITY FLAG, $=1$ VARIABLE VISCOSITY FORMULA'TION, $=0$ CONSTANT VISCOSITY FORMULATION

IS DO-LOOP INDEX

IS NUMBER OF MESH CELLS IN THE X-DIRECTION IN THE REGION

IS JMAX-1

IS JMAX-2 


\begin{tabular}{|c|c|c|}
\hline JMAX & IS & $\begin{array}{l}\text { NUMBER OF CELLS IN THE Y-DIRECTION OF THE AUGMENTED } \\
\text { REGION INCLUDES THE BOUNDARY CELLS. }\end{array}$ \\
\hline JSTART & IS & STARTING VALUE FOR DO-LOOP WITH INDEX J \\
\hline JSTOP & IS & STOPPING VALUE FOR DO-LOOP WITH INDEX J \\
\hline JSTRM1 & IS & JSTART - 1 \\
\hline $\mathrm{K}$ & IS & DO-LOOP INDEX \\
\hline KBAR & IS & $\begin{array}{l}\text { NUMBER OF MESH CELLS IN THE Z-DIRECTION IN THE } \\
\text { REGION }\end{array}$ \\
\hline KM1 & IS & KMAX-1 C \\
\hline KM2 & IS & KMAX-2 \\
\hline KMAX & IS & $\begin{array}{l}\text { NUMBER OF CELLS IN THE Z-DIRECTION OF THE AUGMENTED } \\
\text { REGION INCLUDES THE BOUNDARY CELLS. }\end{array}$ \\
\hline NAME & IA & $\begin{array}{l}\text { HOLDS CHARACTER DATA. WITH TITLE OF PROBLEM BEING } \\
\text { RUN. }\end{array}$ \\
\hline NBC & IS & NUMBER OF BOUNDARY CELLS \\
\hline NCELLS & IS & NUMBER OF ACTIVE CELLS IN COMPUTATIONAL REGION \\
\hline NU & RS & VISCOSITY \\
\hline NXD & IS & ABSOLUTE MAXIMUM X DIMENSION \\
\hline NYD & IS & ABSOLUTE MAXIMUM Y DIMENSION \\
\hline NZD & IS & ABSOLUTE MAXIMUM Z DIMENSION \\
\hline OMG & RS & OMEGA, SAFETY FACTOR \\
\hline OMG1 & RS & OMEGA 1, SAFETY FACTOR FOR PHYSICAL TIME STEP \\
\hline OMG2 & RS & OMEGA2, SAFETY FACTOR FOR ARTIFICLAL TIME STEP \\
\hline $\mathrm{P}$ & RA & PRESSURE FIELD; DOUBLY INDEXED ARRAY \\
\hline QDOT & RA & ENERGY GENERATION ARRAY \\
\hline $\mathrm{RC}$ & $\mathrm{RA}$ & $\begin{array}{l}\text { ARRAY CONTAINING X-VALUES AT CELL CENTERS FOR USE } \\
\text { IN THE 2-D CYLINDRICAL COORDINATES FORMULATION }\end{array}$ \\
\hline $\mathrm{RR}$ & RA & $\begin{array}{l}\text { ARRAY CONTAINING X-VALUES AT CELL RIGHT FACES FOR } \\
\text { USE IN THE 2-D CYLINDRICAL COORDINATES FORMULATION }\end{array}$ \\
\hline RDX & RS & 1/DX. USED IO AVOID FLOATING POINT DIVISION IN LOOPS \\
\hline RDX4 & RS & $1 /(4 * \mathrm{DX})$ \\
\hline RDXSQ & RS & $1 /(\Gamma * D X)$ \\
\hline RDY & RS & 1/DY. IBID. \\
\hline RDY4 & RS & $1 /(4 * D Y)$ \\
\hline RDYSQ & RS & 1/(DY*DY) \\
\hline RDZ & RS & 1/DZ. IBID. \\
\hline
\end{tabular}

$$
\text { C. } 11
$$




\begin{tabular}{|c|c|c|}
\hline RDZA & RS & $1 /(4 * \mathrm{DZ})$ \\
\hline RDZSQ & RS & 1/(DY*DZ) \\
\hline RHO & RS & FLUID DENSITY \\
\hline RNUDT & RS & VISCOSITY OF THE DERRIERE-TOP CELL EDGE \\
\hline RNUFB & RS & VISCOSITY OF THE FRONT-BOTTOM CELL EDGE \\
\hline RNUFT & RS & VISCOSITY OF THE FRONT-TOP CELL EDGE \\
\hline RNULF & RS & VISCOSITY OF THE LEFT-FRONT CELL EDGE \\
\hline RNULT & RS & VISCOSITY OF THE LEFT-TOP CELL EDGE \\
\hline RNURB & RS & VISCOSITY OF THE RIGHT-BOTTOM CELL EDGE \\
\hline RNURD & RS & VISCOSITY OF THE RIGHT-TOP CELL EDGE \\
\hline RNURF & RS & VISCOSITY OF THE RIGHT-FRONT CELL EDGE \\
\hline RNURT & RS & VISCOSITY OF THE RIGHT-TOP CELL EDGE \\
\hline RXIJJX2 & RS & MULTIPLIER IN RZ GEOMETRY MOMENTUM EQUATION \\
\hline RXIHDX & RS & MULTIPLIER IN RZ GEOMETRY MOMENTUM EQUATION \\
\hline RXISQ & RS & MULTIPLIER IN RZ GEOMETRY MOMENTUM EQUATION \\
\hline SIGMA & RA & ELECTRICAL CONDUCTIVITY ARRAY \\
\hline STARTM & RS & $\begin{array}{l}\text { TIME ON THE INTERNAL CLOCK WHEN THE RUN WAS } \\
\text { STARTED }\end{array}$ \\
\hline STLOOP & RS & $\begin{array}{l}\text { TIME ON THE INTERNAL CLOCK WHEN THE LOOP WAS } \\
\text { STARTED }\end{array}$ \\
\hline SUR & RS & SUM OF U(I,J,K) AND ITS RIGHT NEIGHBOR \\
\hline SUF & RS & SUM OF U(I,J,K) AND ITS FRONT NEIGHBOR \\
\hline SUD & RS & SUM OF U(I,J,K) AND ITS DERRIERE NEIGHBOR \\
\hline SULF & RS & $\begin{array}{l}\text { SUM OF U(I-1,J,K) AND ITS FRONT NEIGHBOR SULT RS SUM } \\
\text { OF U(I-1,J,K) AND ITS TOP NEIGHBOR }\end{array}$ \\
\hline SUL & RS & SUM OF U(I,J,K) AND ITS LEFT NEIGHBOR \\
\hline SUT & RS & SUM OF U(I,J,K) AND ITS TOP NEIGHBOR \\
\hline SUB & RS & SUM OF U(I,J,K) AND ITS BOTTOM NEIGHBOR \\
\hline SVR & RS & SUM OF V(I,J,K) AND ITS RIGHT NEIGHBOR \\
\hline SVF & RS & SUM OF V(I,J,K) AND ITS FRONT NEIGHBOR \\
\hline SVB & RS & SUM OF V(I,J,K) AND ITS DERRIERE NEIGHBOR \\
\hline SVDR & RS & SUM OF V(I,J-1,K) AND ITS RIGHT NEIGHBOR \\
\hline SVDT & RS & SUM OF V(I,J-1,K) AND ITS TOP NEIGHBOR \\
\hline SVL & RS & SUM OF V(I,J,K) AND ITS LEFT NEIGHBOR \\
\hline SVT & RS & SUM OF V(I,J,K) AND ITS TOP NEIGHBOR \\
\hline SVB & RS & SUM OF V(I,J,K) AND ITS BOTTOM NEIGHBOR \\
\hline
\end{tabular}




\begin{tabular}{|c|c|c|}
\hline SWR & RS & SUM OF W(I,J,K) AND ITS RIGHT NEIGHBOR \\
\hline SWF & RS & SUM OF W(I,J,K) AND ITS FRONT NEIGHBOR \\
\hline SWB & RS & SUM OF W(I,J,K) AND ITS DERRIERE NEIGHBOR \\
\hline SWBF & RS & SUM OF W(I,J,K-1) AND ITS FRONT NEIGHBOR \\
\hline SWBR & RS & SUM OF W(I,J,K-1) AND ITS RIGHT NEIGHBOR \\
\hline SWL & RS & SUM OF W(I,J,K) AND ITS LEFT NEIGHBOR \\
\hline SWT & RS & SUM OF W(I,J,K) AND ITS TOP NEIGHBOR \\
\hline SWB & RS & SUM OF W(I,J,K) AND ITS BOTTOM NEIGHBOR \\
\hline \multirow[t]{2}{*}{ SXXR } & RS & VISCOUS STRESS TERM LOCATED ON THE RIGHT \\
\hline & & FACE OF THE X-MOMENTUM CELL \\
\hline \multirow[t]{2}{*}{ SXXL } & RS & VISCOUS STRESS TERM LOCATED ON THE LEFT \\
\hline & & FACE OF THE X-MOMENTUM CELL \\
\hline SXYLF & RS & VISCOUS STRESS TERM ON THE LEFT-FRONT CELL EDGE \\
\hline SXYRD & RS & VISCOUS STRESS TERM ON THE RIGHT-DERRIERE CELL EDGE \\
\hline SXYRF & RS & VISCOUS STRESS TERM ON THE RIGHT-FRONT CELL EDGE \\
\hline SXZLT & RS & VISCOUS STRESS TERM ON THE LEFT-TOP CELL EDGE \\
\hline SXZRB & RS & VISCOUS STRESS TERM ON THE RIGHT-BOTTOM CELL EDGE \\
\hline SXZRT & RS & VISCOUS STRESS TERM ON THE RIGHT-TOP CELL EDGE \\
\hline \multirow[t]{2}{*}{ SYYD } & RS & VISCOUS STRESS TERM LOCATED ON THE DERRIERE \\
\hline & & FACE OF THE X-MOMENTUM CELL \\
\hline \multirow[t]{2}{*}{ SYYF } & RS & VISCOUS STRESS TERM LOCATED ON THE FRONT \\
\hline & & FACE OF THE X-MOMENTUM CELL \\
\hline SYZDT & RS & VISCOUS STRESS TERM ON THE DERRIERE-TOP CELL EDGE \\
\hline SYZFB & RS & ISCOUS STRESS TERM ON THE FRONT-BOTTOM CELL EDGE \\
\hline SYZFT & RS & VISCOUS STRESS TERM ON THE FRONT-TOP CELL EDGE \\
\hline \multirow[t]{2}{*}{ SZZB } & RS & VISCOUS STRESS TERM LOCATED ON THE BOTTOM \\
\hline & & FACE OF THE X-MOMENTUM CELL \\
\hline \multirow[t]{2}{*}{ SZZT } & RS & VISCOUS STRESS TERM LOCATED ON THE TOP \\
\hline & & FACE OF THE X-MOMENTUM CELL \\
\hline $\mathrm{T}$ & RS & CUMULATIVE TIME \\
\hline TAVE & RS & AVERAGE TEMP. IN COMPUTATIONAL REGION \\
\hline TCRNTU & RS & COURANT TIME: STEP LIMIT BASED ON U-VELOCITY \\
\hline TCRNTV & RS & COURANT TIME STEP LIMIT BASED ON V-VELOCITY \\
\hline TCRNTW & RS & COURANT TIME STEP LIMIT BASED ON W-VELOCITY \\
\hline TMP & RA & TEMPERATURE ARRAY \\
\hline TNU & $\mathrm{RA}$ & TEMPERATURE DEPENDENT VISCOSITY ARRAY \\
\hline & & C. 13 \\
\hline
\end{tabular}


TQB

TQD

TQF

TQL

TQR

TQT

TREF

TWFIN

TWPLT

TWPRT

$\mathrm{U}$

UI

UMAX

UN

US

UTLDA

V

VELMX

VELMX1

VI

VISX

VISY

VISZ

VMAX

VN

VS

VTLDA
RS

RS

RS

RS

RS

RS

RS

RS

RS

RS

RA

RS

RS

RA

RA

RA

TEMP. B.C. PARAMETER FOR BOTTOM OF REGION

TEMP. B.C. PARAMETER FOR DERRIERE OF REGION

TEMP. B.C. PARAMETER FOR FRONT OF REGION

TEMP. B.C. PARAMETER FOR LEFT OF REGION

TEMP. B.C. PARAMETER FOR RIGHT OF REGION

TEMP. B.C. PARAMETER FOR BOTTOM OF REGION

REFERENCE TEMPERATURE

FINISH TIME. STOP CALCULATION WHEN T $=$ TWFIN.

PLOTTING TIME. WRITE A PLOT WHENEVER $T=$ TWPLT.

EDITTING TIME. WRITE OUTPUT EDIT WHENEVER T $=$ TWPRT .

$X$-DIRECTION VELOCITY ITERATE VECTOR FOR SOR.

UNIFORM INITIAL U-VELOCITY

MAXIMUM VALUE OF THE U-VELOCITY IN THE REGION

$X$-DIRECTION VELOCITY FIELD A TIME-STEP N.

X-DIRECTION SPECIFIED VELOCITY FIELD

$X$ X-COMPONENT OF VELOCITY CONSISTING OF THE VELOCITY OF THE PREV. TIME STEP PLUS THE CONVECTIVE AND VISCOUS FLUXES ASSOCIATED WITH THE CURRENT ITERATE FOR THE VELOCITY.

RA Y-DIRECTION VELOCITY ITERATE VECTOR FOR SOR.

RS MAXIMUM EXPECTED VELOCITY AT ANY POINT AND TIME

RS THE MAXIMUM MESH-SPACING DIVIDED BY VELMX

RS UNIFORM INITIAL V-VELOCITY

RS VISCOUS DIFFUSION TERM IN THE X-DIRECTION MOMENTUM EQUATION

RS VISCOUS DIFFUSION ?. .RM IN THE Y-DIRECTION MOMENTUM EQUATTON

RS VISCOUS DIFFUSION TERM IN THE Z-DIRECTION MOMENTUIM EQUATION

RS MAXIMUM VALUE OF THE V-VELOCITY IN THE REGION

RA Y-DIRECTION VELOCITY FIELD A TIME-STEP N.

RA Y-DIRECTION SPECIFIED VELOCITY FIELD

RA Y-COMPONENT OF VELOCITY CONSISTING OF THE VELOCITY OF THE PREV. TIME STEP PLUS THE CONVECTIVE AND VISCOUS FLUXES ASSOCIATED WITH THE CURRENT ITERATE OF THE VELOCTTY.

C. 14 
W

WI

WMAX

WN

WTLDA
RA Z-DIRECTION VELOCITY ITERATE VECTOR FOR SOR.

R.S UNIFORM INITIAL W-VELOCITY

RS MAXIMUM VALUE OF THE W-VELOCITY IN THE REGION

RA W-DIRECTION VELOCITY FIELD A TIME-STEP N.

RA Z-COMPONENT OF VELOCITY CONSISTING OF THE VELOCITY OF THE PREV. TIME STEP PLUS THE CONVECTIVE AND VISCOUS FLUXES ASSOCIATED WITH THE CURRENT ITERATE OF THE VELOCITY.

ADDRESS $\quad==>$ DEFINES THE INDIRECT ADDRESSING SCHEME

ADVANCE $\quad==\quad$ UPDATES VARIABI,ES TO THE NEW TIME LEVEL

BNDRY $\quad \Rightarrow \quad$ SETS THE BOUNDARY CONDITIONS

CONVERG $\quad \Rightarrow \quad$ CHECKS FOR CONVERGENCE OF THE ITERATION SCHEME

DENCHK $\quad \Rightarrow \quad$ COMPUTES THE DEVIATION FROM INCOMPRESSIBILITY

DUMP $\quad \Rightarrow \quad$ PERFORMS BINARY DUMP OF DATA FOR RESTART

ENERGY $\quad \Rightarrow \quad$ SOLVES DISCRETI'ZED FORM OF ENERGY EQUATION (EXPLICIT)

FLUX $\quad==>$ COMPUTES THE VELOCITY CONTRIBUTIONS DUE TO THE CONVECTIVE, VISCOUS, AND BODY FORCE IERMS IN THE MOMEMTUM EQUATION

GUESS $\quad \Rightarrow \quad=>$ SETS THE INITLAL VELOCITY GUESS FOR THE ITERATION SCHEME --> 1.) EXPLICIT APPROX. TO MOM. EQ.

2.) OLD TIME VELOCITIES

3.) EXTRAPOLATION FROM 2 PREV. TIME IEVELS

INITLZ $\quad \Rightarrow \quad$ INITIALIZES PROGRAM VARIABLES

INPUT $\quad=\Rightarrow$ INPUTS THE NECESSARY VARIABLES

MELT $\quad \Rightarrow \quad$ ALLOWS CEILL MELTING AND FREEZING

PRNT $\quad=\Rightarrow$ PRINTS INFORMATION FOR OUTPUT AND PLOTTING

RSTAKT $\quad==$ READS BINARY DATA FILE FOR PROGRAM RESTART

C. 15 
STATE $\quad \Rightarrow \quad=>\quad$ USES EQ. OF STATE TO COMPUTE TEMP. OR ENERGY ALSO COMPUTES TEMP. DEPENDENT FLUID PROPERTIES

TBNDRY $\Rightarrow$ SETS TEMPERATURE BOUNDARY CDNDITIONS

TIMER $\quad \Rightarrow$ TIMES PROGRAM

UPDATE $\quad \Rightarrow \quad$ UPDATES PRESSURES AND VELOCITIES ACCORDING TO FULLY/LINEARLY IMPLICIT ARTIFICIAL COMPRESSIBILITY ITERATION SCHEME WITH DAMPING 


\section{APPENDIX D}

\section{SAMPLE INPUT FILE}

$$
\text { D. } 1
$$




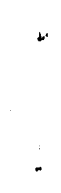

D. 2 


\section{APPENDIX D}

\section{SAMPLE INPUT FILE}

MAGMA TEST PROBLEM - 3B

C..4..7.10..3..6..20

0 IRSTRT RESTART PARAMETER $=0$,INPUT FILE; $=1$, RESTART FILE

1.000 ALPHA WEIGHTING FACTOR FOR AVE. UPWIND AND CENT'ER DIFF.

\begin{tabular}{|c|c|c|}
\hline $1.0 \mathrm{E}+00$ & BCTE & BETA--COEFFICIENT OF THERMAL EXPANSION \\
\hline $1.00 \mathrm{D}+00$ & CVREF & REFERENCE SPECIFIC HEAT CAPACITY \\
\hline $0 . \mathrm{DO}$ & CYL & CYLINDRICAL/RECTANGULAR COORDINATES INDICATOR \\
\hline $1.0 \mathrm{E}+00$ & DELT & TIME STEP \\
\hline $2.500000 \mathrm{E}-02$ & DELIX & X-DIRECTION MESH SPACING \\
\hline $2.500000 \mathrm{E}-() 2$ & DELY & Y-DIRECTION MESH SPACING \\
\hline$-2.50 \mathrm{E}-() 2$ & DELZ & Y-DIRECTION MESH SPACING $(<0$ for 2-D) \\
\hline $1 . \mathrm{DO}$ & DZRO & $\begin{array}{l}\text { BENCHMARK VALUE FOR DIVERGENCE OF VELOCITY } \\
\text { FIELD }\end{array}$ \\
\hline $1 .(00 \mathrm{D}+() 0$ & ECOEF1 & COEFF. IN ENERGY EQ. OF STATE (LINEAR TERM) \\
\hline $0.0 \mathrm{D}-00$ & $\mathrm{ECOEF} 2$ & COEFF. IN ENERGY EQ. OF STATE (QUADRATIC TERM) \\
\hline $1.00 \mathrm{D}+00$ & ECOEF3 & COEFF. IN ENERGY EQ. OF STATE (LINEAR TERM) \\
\hline $0.0 \mathrm{D}-00$ & ECOEF4 & COEFF. IN ENERGY EQ. OF STATE (QUADRATIC TERM) \\
\hline $1.0 \mathrm{E}-05$ & EPSI & CONVERGENCE CONDITION \\
\hline $1.00000 \mathrm{E}-00$ & FKREF & REFERENCE THERMAL CONDUCTIVITY \\
\hline $0.0 \mathrm{D}+00$ & $\mathrm{FL}$ & SPECIFIC LATENT HEAT OF FUSION \\
\hline 1.000 & FLCHAK & CHARACTERISTIC LENGTH \\
\hline $0 . \mathrm{DO}$ & GX & BODY ACCELERATION IN X DIRECTION \\
\hline 9.8100 & GY & BODY ACCELERATION IN Y DIRECTION \\
\hline $0 . \mathrm{DO}$ & $\mathrm{GZ}$ & BODY ACCELERATION IN Z DIRECTION \\
\hline $0.71000 \mathrm{D}-00$ & NU & VISCOSITY \\
\hline 1.47500 & OMG & EFFECTIVE DAMPING COEFFICIENT \\
\hline $0.80 \mathrm{DOO}$ & OMG1 & SAFETY FACTOR FOR PHYSICAL TIME STEP \\
\hline $0.80 \mathrm{D} 00$ & OMG2 & SAFETY FACTOR FOR ARTIFICIAL TIME STEP \\
\hline $1.0 \mathrm{D} 00$ & RHO & REFERENCE DENSITY \\
\hline $1.0 \mathrm{E}-03$ & TOL & TOLERANCE OF DU/DTAU \& DV/DTAU \\
\hline $661.88 \mathrm{D}+00$ & TMPI & INITIAL TEMPERATURE \\
\hline
\end{tabular}




\begin{tabular}{|c|c|c|}
\hline $0.0 \mathrm{E}+00$ & TQB & TEMP./HEAT FLUX FOR BOTTOM BOUNDARY COND. \\
\hline $0.0 \mathrm{D}+00$ & TQD & TEMP,/HEAT FLUX FOR DERRIERE BOUNDARY COND. \\
\hline $0.0 \mathrm{E}+00$ & TQF & TEMP./HEAT FLUX FOR FRONT BOUNDARY COND. \\
\hline $0.0 \mathrm{E}+00$ & $\mathrm{TQH}$ & HEAT TRANSFER COEFF. FOR MIXED TYPE B.C. \\
\hline $1.0238 \mathrm{E}+03$ & TQL & TEMP./HEAT FLUX FOR LEFT BOUNDARY COND. \\
\hline $3.0 \mathrm{E}+02$ & TQR & TEMiP./HEAT FLUX FOR RIGHT BOUNDARY COND. \\
\hline $0.0 \mathrm{E}+00$ & TQT & TEMP./HEAT FLUX FOR TOP BOUNDARY COND. \\
\hline 661.880 .00 & TREF & REFERENCE TEMPERATURE \\
\hline $1.00000 \mathrm{D}-00$ & TWFIN & S'TOPPING TIME \\
\hline $0.0 \mathrm{DO}$ & UI & INITIAL U-VELOCITY \\
\hline $2.5 \mathrm{D}+01$ & VELMX & MAXIMUM EXPECTED VELOCITY \\
\hline $0.0 \mathrm{DO}$ & VI & INITIAL Y-VELOCITY \\
\hline $0.0 \mathrm{DO}$ & WI & INITIAL Z-VELOCITY \\
\hline \multirow{3}{*}{\multicolumn{3}{|c|}{ C INTEGER SCALARS }} \\
\hline & & \\
\hline & & \\
\hline 100 & IFREQ & PLOT EVERY IFREQ CYCLES \\
\hline 40 & IBAR & MAX. NO. OF INTERIOR CELLS IN X-DIRECTION \\
\hline 40 & BAR & MAX. NO. OF INTERIOR CELLS IN Y-DIRECTION \\
\hline 1 & KBAR & MAX. NO. OF INTERIOR CELLS IN Z-DIRECTION \\
\hline 1 & IENRGY & $=0$ NO ENERGY CALCULATIONS,$=\_$ENERGY CALC.S \\
\hline 0 & IFIMP & $=0$ FULLY IMPLCT $=1$ LINEARI $Y$ IMPLCT $=2$ SEMI $-I M P L C T$ \\
\hline 1 & IGUESS & $\begin{array}{l}=0 \text { NORMAL GUESS, =1 OLD VEL., = } 2 \text { EXTRAPOLATED } \\
\text { VEL. }\end{array}$ \\
\hline 0 & IMELT & $=0$ NO MELTING,$=1$ MELTING ALLOWED \\
\hline 2 & ITMPB & $=1$ CONST $T,=2$ CONST $Q,=3$ CONVECTIVE B.C. \\
\hline 2 & ITMPD & $=1 \operatorname{CONST} \mathrm{T},=2$ CONST $Q,=3$ CONVECTIVE B.C. \\
\hline 2 & ITMPF & $=1 \operatorname{CONST} T,=2$ CONST $Q,=3$ CONVECTIVE B.C. \\
\hline 1 & ITMPL & $=1$ CONST T, $=2$ CONST Q, =3 CONVECTIVE B.C. \\
\hline 1 & ITMPR & $=1$ CONST $T,=2$ CONST $Q,=3$ CONVECTIVE B.C : \\
\hline 2 & ITMPT & $=1$ CONST $T,=2$ CONST $Q,=3$ CONVECTIVE B.C. \\
\hline 0 & IVISC & $=0$ TURNS OFF VARIABLE VISCOSITY FORMULATION \\
\hline
\end{tabular}



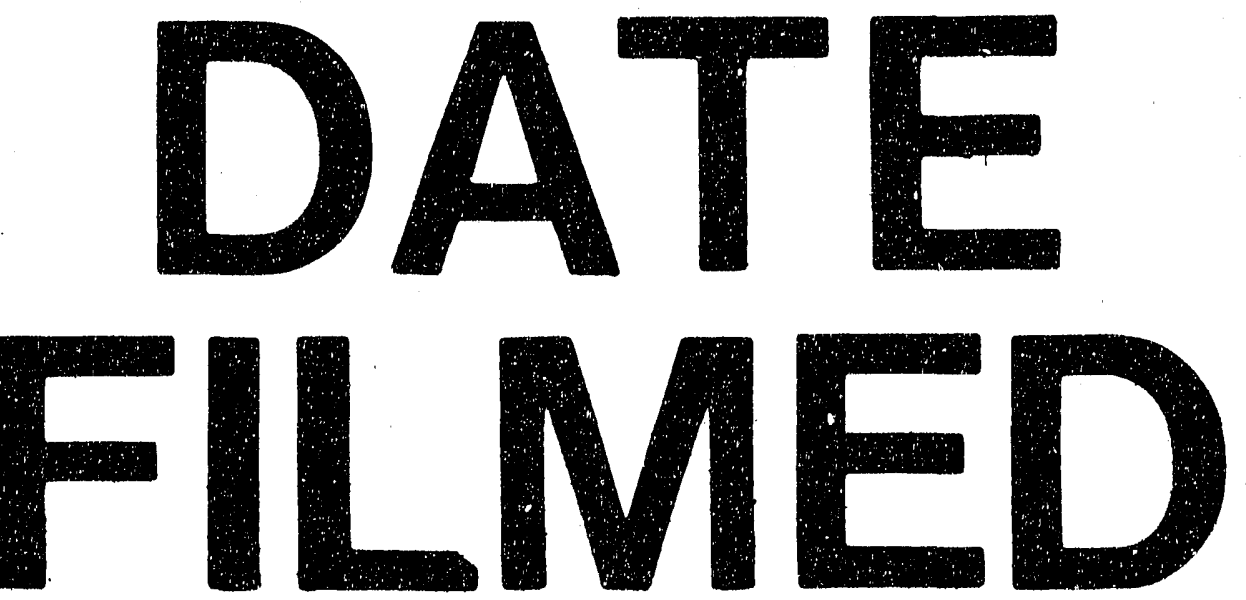

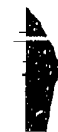
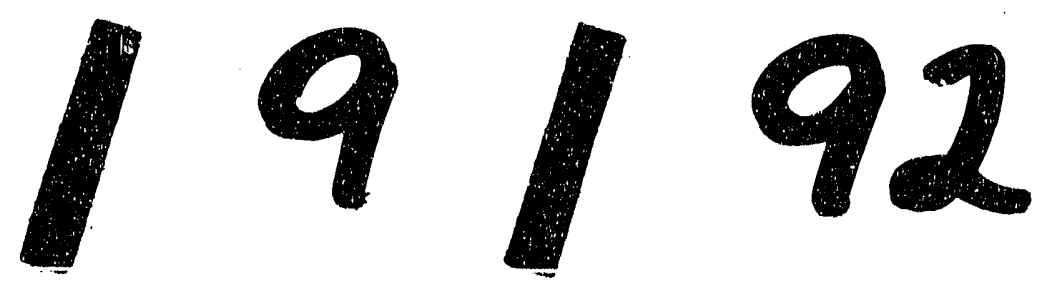
